\author{
UNIVERSIDADE DE SÃO PAULO \\ ESCOLA DE ENGENHARIA DE SÃO CARLOS \\ FACULDADE DE MEDICINA DE RIBEIRÃO PRETO \\ INSTITUTO DE QUÍMICA DE SÃO CARLOS
}

GABRIELA CASEIRO ALMEIDA SILVA

NOVAS TECNOLOGIAS ROBÓTICAS PARA O TRATAMENTO DE ALTERAÇÕES MOTORAS NO MEMBRO SUPERIOR 


\author{
UNIVERSIDADE DE SÃO PAULO \\ ESCOLA DE ENGENHARIA DE SÃO CARLOS \\ FACULDADE DE MEDICINA DE RIBEIRÃO PRETO \\ INSTITUTO DE QUÍMICA DE SÃO CARLOS
}

GABRIELA CASEIRO ALMEIDA SILVA

\title{
NOVAS TECNOLOGIAS ROBÓTICAS PARA O TRATAMENTO DE ALTERAÇÕES MOTORAS NO MEMBRO SUPERIOR
}

New robotic technologies for treatment of motor arm disorders

Dissertação apresentada ao Programa de PósGraduação Interunidades em Bioengenharia-Escola de Engenharia de São Carlos / Faculdade de Medicina de Ribeirão Preto / Instituto de Química de São Carlos da Universidade de São Paulo para obtenção do título de Mestre em Ciências.

Área de Concentração: Bioengenharia

Orientadora: Prof. Dr. Valéria M. Carril Elui 


\section{AUTORIZO A REPRODUČ̃O TOTAL OU PARCIAL DESTE TRABALHO, POR QUALQUER MEIO CONVENCIONAL OU ELETRÔNICO, PARA FINS DE ESTUDO E PESQUISA, DESDE QUE CITADA A FONTE.}

Ficha Catalográfica preparada pela Seção de Atendimentos ao Usuário do Serviço da Biblioteca EESC/USP

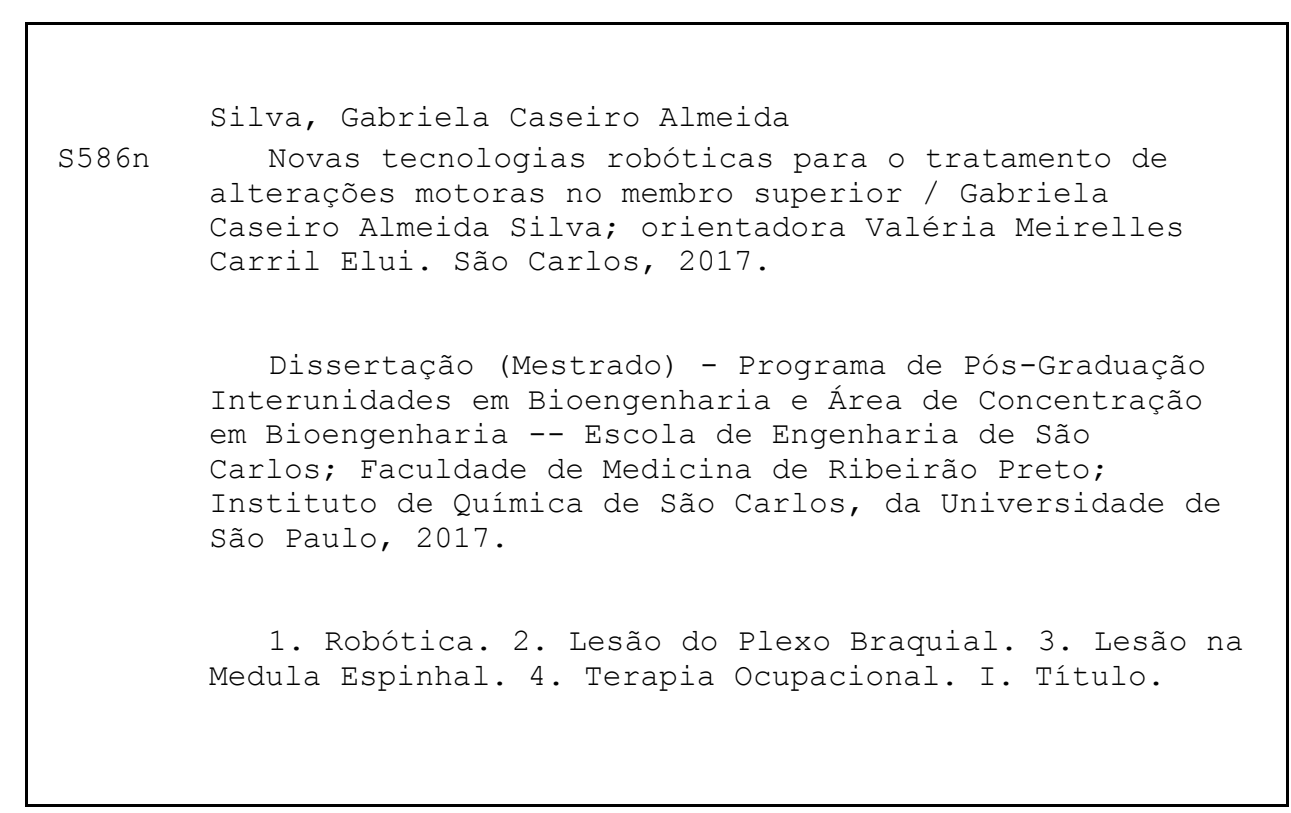




\section{FOLHA DE APROVAÇÃO}

\section{GABRIELA CASEIRO ALMEIDA SILVA}

Título da dissertação:

\section{"NOVAS TECNOLOGIAS ROBÓTICAS PARA O TRATAMENTO DE ALTERAÇÕES} MOTORAS DO MEMBRO SUPERIOR"

"NEW ROBOTIC TECHNOLOGIES FOR TREATMENT OF MOTOR ARM DISORDERS"

DISSERTAÇÃO APRESENTADA AO PROGRAMA DE PÓS - GRADUAÇÃO INTERUNIDADES EM BIOENGENHARIA - EESC/FMRPIIQSC DA UNIVERSIDADE DE SÃO PAULO PARA OBTENÇÃO DO TITULO DE MESTRA EM CIÊNCIAS NA ÁREA DE BIOENGENHARIA.

Data da defesa: 11/12/2017

\begin{tabular}{|l|l|}
\hline $\begin{array}{l}\text { Profa. Dra. Valéria Meirelles Carril Elui } \\
\text { (Orientadora) }\end{array}$ & Faculdade de Medicina de Ribeirão Preto / USP \\
\hline Assinatura: Calería $m e$ Eluc & Não votante \\
\hline
\end{tabular}

\begin{tabular}{|l|l|}
\hline Prof. Dr. Glauco A. de Paula Caurin & Escola de Engenharia de São Carlos / USP \\
\hline Assinatura: & Resultado: Aprovade de \\
\hline Profa. Dra. Cristina Yoshie Toyoda & Universidade Estadual Paulista - UNESP \\
\hline Assinatura: & Resultado: Aprorada \\
\hline
\end{tabular}

\begin{tabular}{|l|l|}
\hline Profa. Dra. Deborah Couto de Melo Carrijo & Universidade de Araraquara - UNIARA \\
\hline Assinatura.18arn & Resultado: aprousa do \\
\hline
\end{tabular}




\section{DEDICATÓRIA}

Aos meus pais, Edson e Ligia, que dignamente me apresentaram à importância da família e ao caminho da conquista baseado na persistência, estudo e dedicação; e ao meu marido Rafael, companheiro de experiências e de vida, pelo apoio, amor e carinho. 


\section{AGRADECIMENTOS}

Agradeço à Dra. Valéria M. Carril Elui, professora e orientadora, que me auxiliou na caminhada da graduação à pós-graduação, com carinho, respeito e disponibilidade na minha aprendizagem e crescimento profissional;

Aos membros do Laboratório de Reabilitação Robótica, Kleber Andrade, Thales Bueno Pasqual, em especial ao professor Dr. Glauco de Paula Caurin, pela parceria, apoio, aprendizado e auxílio durante todo o processo da pós-graduação;

À minha família, pais, irmãs e meu marido Rafael, que me apoiaram durante todo esse processo, fornecendo força e sustentação, com muito amor e carinho;

Aos amigos e colegas de laboratório de pesquisa - LAPITEC, que me auxiliaram com o projeto, dúvidas e permitiram que a amizade e companheirismo fortalecessem essa relação;

Ao Centro de Reabilitação - CER HCFMRP - USP, por possibilitar que a pesquisa pudesse ser concretizada.

Obrigada! 


\section{RESUMO}

SILVA, G. C. A. Novas tecnologias robóticas para o tratamento de alterações motoras no membro superior. 2017. 99 f. Trabalho para defesa da dissertação de mestrado - Programa de Pós-Graduação Interunidades Bioengenharia. EESC/FMRP/IQSC, Universidade de São Paulo, São Carlos, 2017.

O uso de robôs como auxiliares na reabilitação, tanto para ganho de função, como para auxiliar na realização de atividades, é encontrado na literatura em estudos envolvendo acidente vascular encefálico. Diversos dispositivos robóticos têm sido desenvolvidos ao longo da última década para oferecer treinamento sensório-motor direcionado para pacientes com doenças neurológicas, como acidente vascular encefálico, propiciando melhora no desempenho motor dos membros superiores nesta população. Poucos estudos são encontrados sobre o uso de robôs em lesão do plexo braquial ou lesão na medula espinhal. Além disso, há pouca produção nacional relacionada a esse tema. Esse trabalho objetivou-se avaliar o uso de um instrumento robótico, Robô MOREw, que foi desenvolvido pela Escola de Engenharia de São Carlos EESC - USP com o intuito de facilitação e ganho nos movimentos de flexão e extensão de punho. Dessa forma, pretendia-se a verificação do funcionamento do robô como auxiliar de reabilitação através de testes clínicos e sua aplicabilidade com indivíduos que sofreram lesão do plexo braquial ou lesão na medula espinhal. A metodologia escolhida é de Projeto de Produto que utiliza como proposta a divisão do projeto em quatro fases, sendo estas: projeto informacional, projeto conceitual, projeto preliminar e projeto detalhado. Foi dado enfoque ao projeto detalhado em testes de laboratório e clínicos para verificação do funcionamento e aplicabilidade do robô com voluntários. O estudo foi composto por 2 fases: FASE 1 Adequação do MOREw: 10 participantes sem comprometimentos nos membros superiores e sem lesões associadas verificaram o funcionamento do robô. Após isso, modificações necessárias foram efetuadas. FASE 2 - Aplicabilidade do MOREw: Teste com 5 participantes que apresentaram diminuição do movimento no Membro Superior, sendo 3 com lesão do plexo braquial e 2 com lesão na medula espinhal que jogaram por 30 minutos uma vez por semana, durante 12 semanas. Nos resultados notou-se que as adequações do robô MOREw foram de extrema importância para o funcionamento adequado do equipamento robótico utilizado por sujeitos com limitação dos movimentos de membros superiores, tanto em relação à ergonomia, funcionamento do jogo e possibilidades de ajustes em programas de reabilitação. Os sujeitos que fizeram uso por 3 meses referiram grande satisfação, motivação e demonstraram maior empenho na reabilitação com o auxílio robótico, que foram corroborados pelos testes funcionais que apresentaram discreta melhora em relação à Amplitude de Movimento e Força Muscular 
dos membros superiores, além da melhora na pontuação na Escala Específica do Paciente. Assim, MOREw é uma opção a ser utilizada na reabilitação com sujeitos com LM e LPB.

Palavras - Chaves: Robótica; Lesão do plexo braquial, Lesão na Medula Espinhal, Terapia Ocupacional. 


\begin{abstract}
SILVA, G. C. A. New robotic technologies for treatment of motor arm disorders. 2017. 99 f. Paper presented for the defense of Master's Degree dissertation - Bioengineering Interunit Postgraduate Program. EESC/FMRP/IQSC, University of São Paulo, São Carlos, 2017.

The use of robots as aid in rehabilitation to gain function or to assist in activities performance is found in the literature involving stroke. Several robotic devices have been developed over the last decade to provide sensory-motor training in patients with neurological diseases such as stroke, leading to improvement in motor performance of the upper limbs in this population. Few studies using robot assistance are found in injuries like brachial plexus (BPI) or spinal cord (SCI). In addition, there is little national production related to this topic. The aim of this work was to evaluate the use of a robotic instrument, Robot MOREw, which was developed by the Engineering School of São Carlos - EESC - USP with the purpose to facilitate and/or gain wrist flexion and extension movements. Thus, it was intended to verify the functioning of the robot as a rehabilitation aid through clinical tests, and its applicability with individuals who suffered BPI or SCI. The methodology chosen was the Project Product Design that consists of four phases: informational, conceptual, preliminary and detailed project. This study focuses on the detailed project, which was tested at laboratory as well as with volunteers in clinical trials to verify the robot applicability and operation. The study consisted of 2 phases: Phase 1 Adequacy: 10 participants with no involvement in the upper limbs and without associated lesions verified the robot functionality. After that, changes were made to the equipment. Phase 2 - Applicability: Tested with 5 participants who had decreased movement in the Upper Limb, 3 with BPI and 2 with SCI, using it 30 min once a week for 12 weeks. It was noticed that the MOREw adjustments were of extreme importance for the correct functionality of the equipment that was used by clients with upper limb deficit movements, regarding ergonomics aspects, game functioning and rehabilitation programs adjustments. The clients who used it for 3 months reported great satisfaction, motivation and demonstrated greater commitment to rehabilitation with robotic assistance, confirmed by functional tests that showed a slight improvement in relation to the range of motion and muscular strength of the upper limbs, besides the improvement on the Patient Specific Scale. MOREw can be an option for BPI and SCI rehabilitation.
\end{abstract}

Keywords: Robotics; Brachial plexus injury, Injury in the spinal cord, Occupational Therapy. 


\section{LISTA DE FIGURAS}

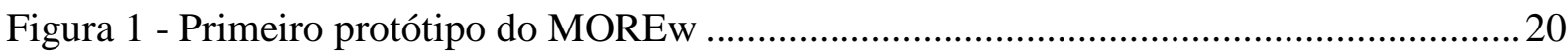

Figura 2 - Ilustração do uso do robô na prática clínica ........................................................ 21

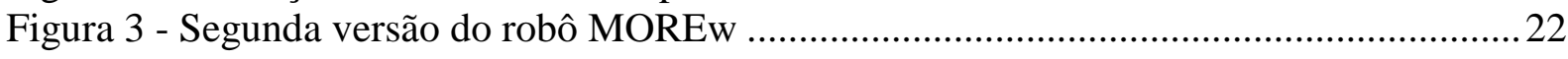

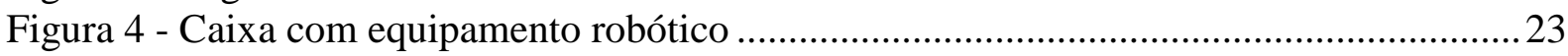

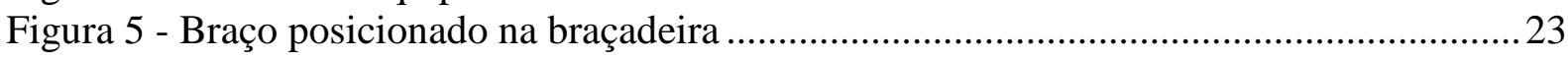

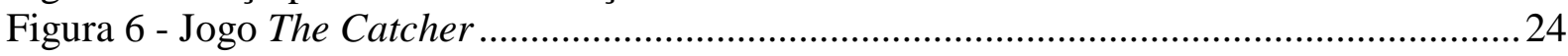

Figura 7 - Braçadeira antiga (material com pouca maleabilidade) ........................................ 42

Figura 8 - Fixação do braço na manopla com tecido de maior conforto .................................... 42

Figura 9 - Luva confeccionada para facilitar a preensão palmar............................................43

Figura 10 - Mesa com regulagem de altura para apoio do robô MOREw................................46

Figura 11 - Botão pause de emergência/segurança e caixa de indicativos .............................. 48

Figura 12 - Perspectiva futura do robô MOREw................................................................ 51

Figura 13 - Robô MOREw adequado para Fase 2 .............................................................5

Figura 14 - Alça confeccionada para fixar mão na manopla do robô......................................66

Figura 15 - Dificuldade na aproximação do corpo ao robô MOREw ......................................67

Figura 16 - Dificuldade na regulagem da altura do robô MOREw junto ao corpo ...................67 


\section{LISTA DE GRÁFICOS}

Gráfico 1 - Orientações fornecidas antes do jogo.............................................................. 40

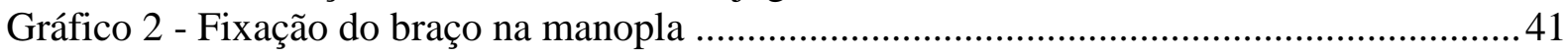

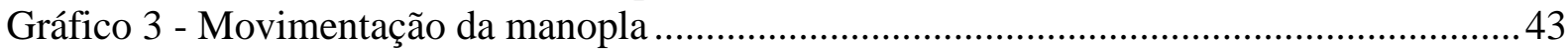

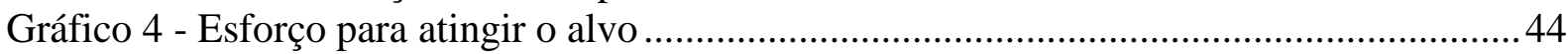

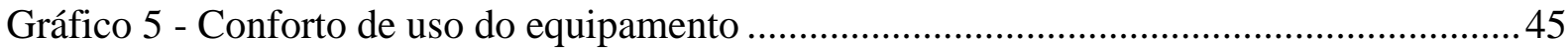

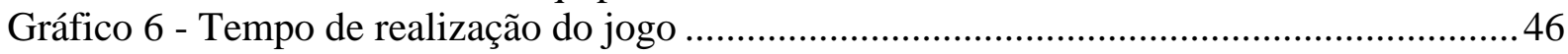

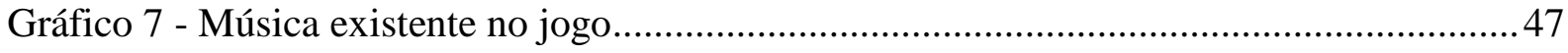

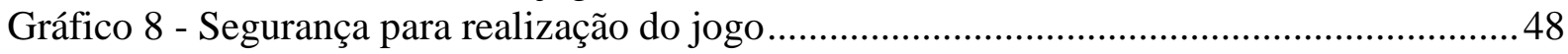

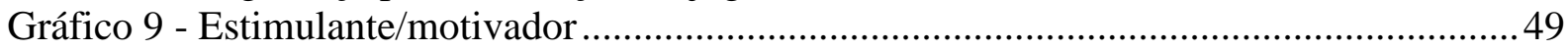

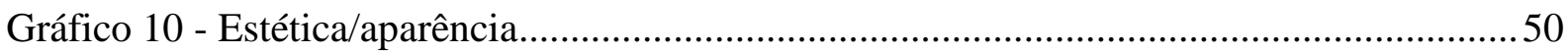

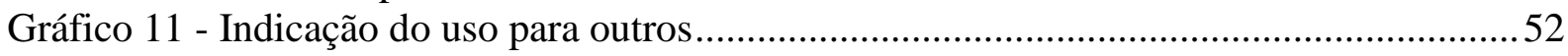

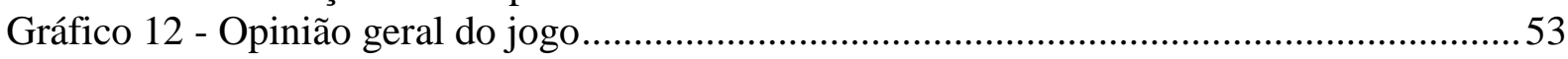

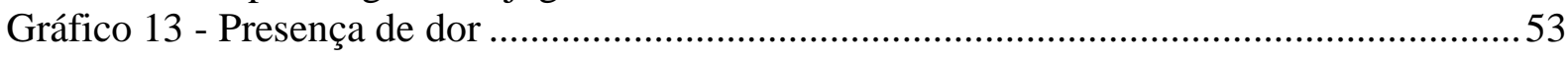




\section{LISTA DE TABELAS}

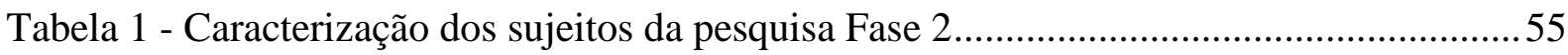

Tabela 2 - Pontuações dos sujeitos de acordo com as escalas utilizadas ................................60

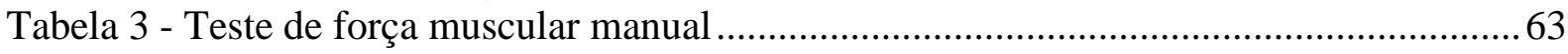

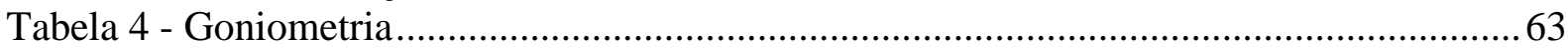

Tabela 5 - Protocolo Think aloud avaliação final após três meses ........................................... 65

Tabela 6 - Questionário satisfação/dificuldade* com o uso do robô MOREw avaliação final

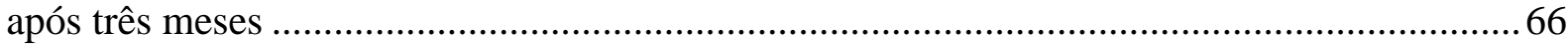

\section{LISTA DE QUADROS}

Quadro 1 - Grau e resistência aplicada no teste de força manual 


\title{
LISTA DE SIGLAS E ABREVIAÇÕES
}

\author{
ADM - Amplitude de movimento \\ AVE - Acidente vascular encefálico \\ CEP - Comitê de Ética em pesquisa \\ CER - Centro de Reabilitação \\ EESC - Escola de Engenharia de São Carlos
}

HCFMRP - Hospital das Clínicas da Faculdade de Medicina de Ribeirão Preto

LM - Lesão medular

LME - Lesão na medula espinhal

LPB - Lesão do plexo braquial

MIF - Medida de Independência Funcional

MMII - Membros inferiores

MMSS - Membros superiores

TCLE - Termo de Consentimento Livre e Esclarecido

TMM - Teste Muscular Manual

TRM - Trauma raquimedular

USP - Universidade de São Paulo 


\section{SUMÁRIO}

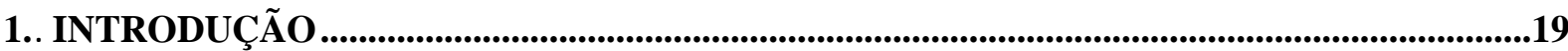

1.1. Histórico de desenvolvimento do robô MOREw ......................................................19

1.2. Componentes e funcionamento do robô MOREw.......................................................23

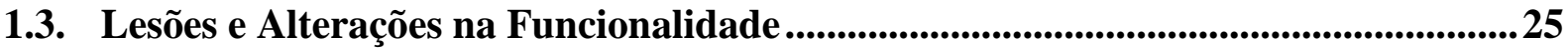

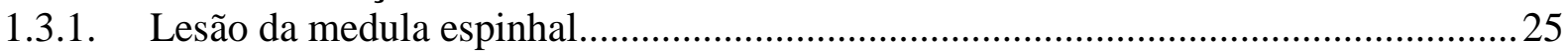

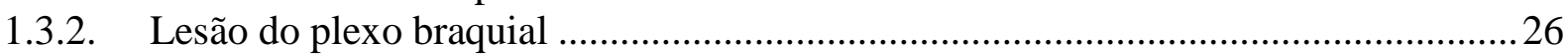

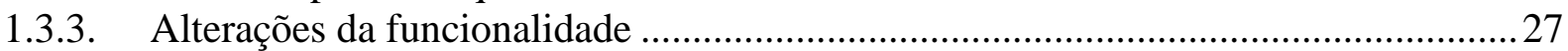

2.. JUSTIFICATIVA E RELEVÂNCIA DO ESTUDO....................................................................29

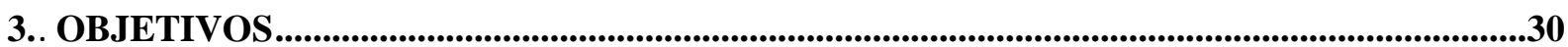

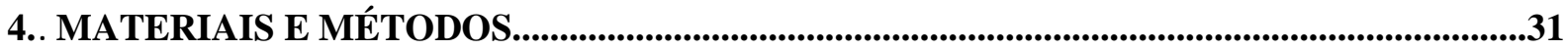

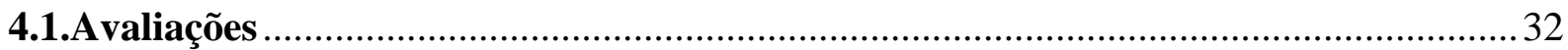

4.2. Fase 1: adequação do MOREw ........................................................................................35

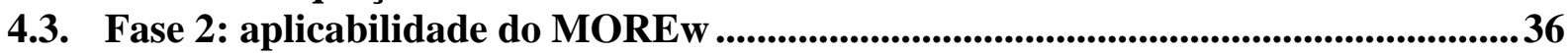

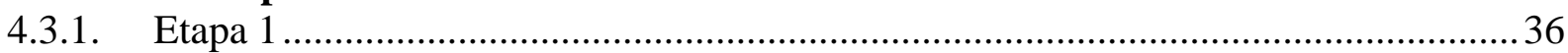

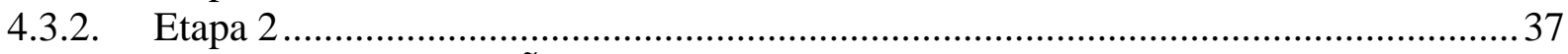

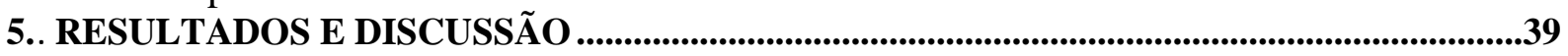

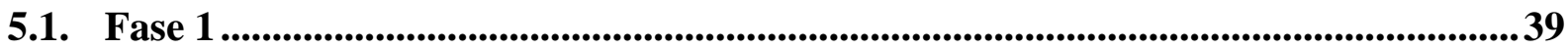

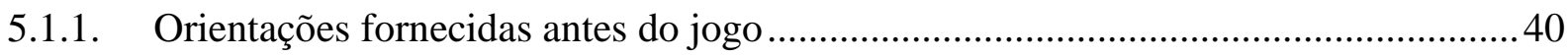

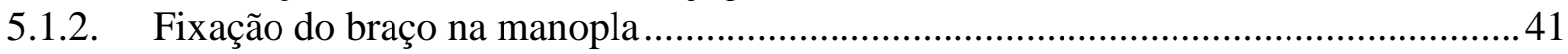

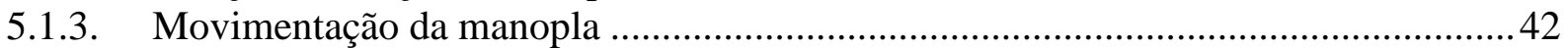

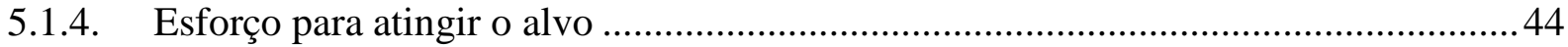

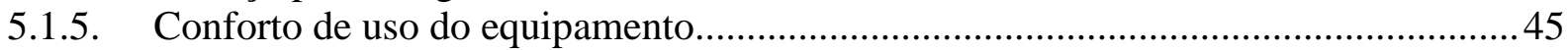

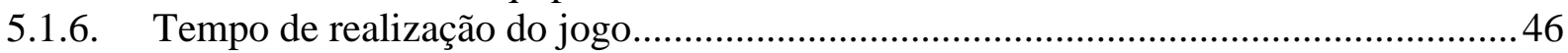

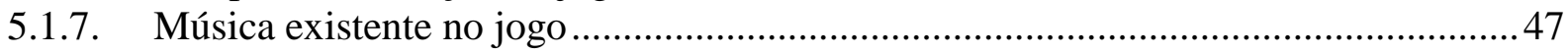

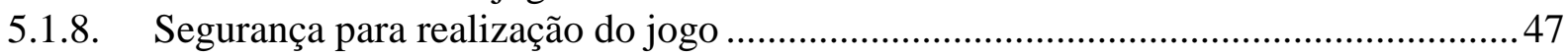

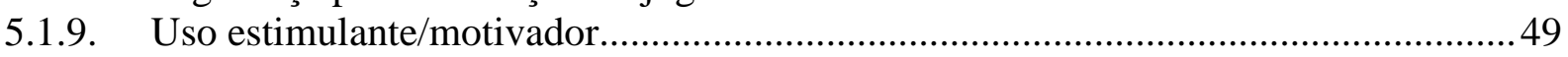

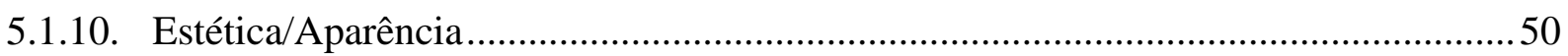

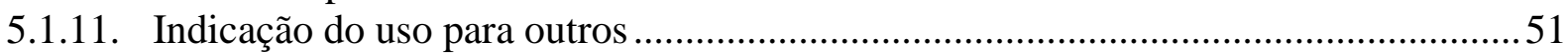

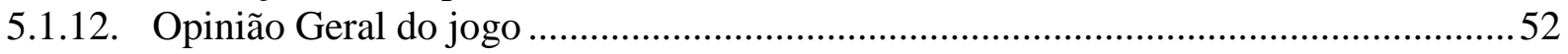

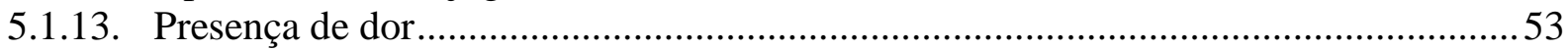

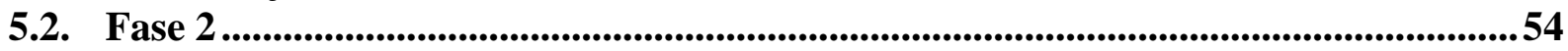

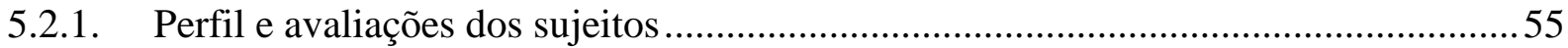

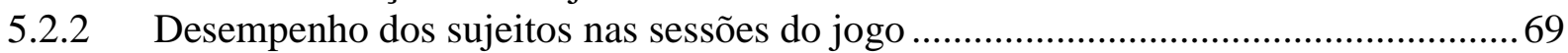

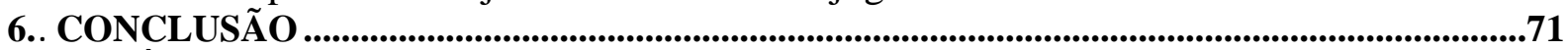

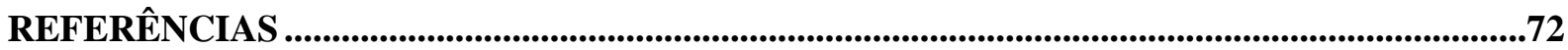

APÊNDICE A - PROTOCOLO THINK ALOUD - PENSE ALTO ................................................78

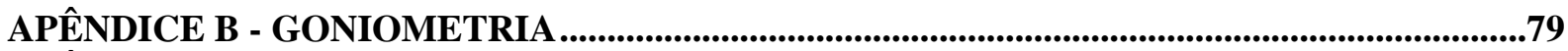

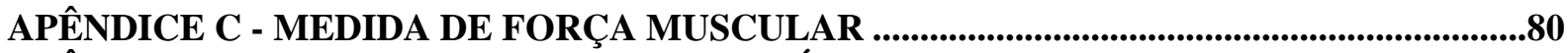

APÊNDICE D - ESCALA FUNCIONAL ESPECÍFICA DO PACIENTE ............................................81

APÊNDICE E - MEDIDA DE INDEPENDÊNCIA FUNCIONAL - MIF ......................................83

APÊNDICE F - QUESTIONÁRIO DE SATISFAÇÃO/DIFICULDADE COM O MOREW .......85

APÊNDICE G - TERMO DE CONSENTIMENTO LIVRE E ESCLARECIDO - FASE 1 ........87

APÊNDICE H - TERMO DE CONSENTIMENTO LIVRE E ESCLARECIDO - FASE 2 .........89

APÊNDICE I - CATEGORIAS DE ANÁLISE DO PROTOCOLO THINK ALOUD ...................91

APÊNDICE J - QUESTIONÁRIO SATISFAÇÃO/DIFICULDADE COM O USO DO ROBÔ

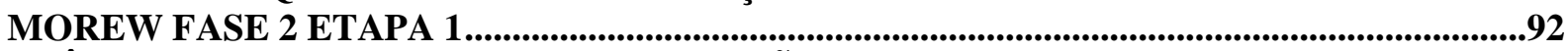

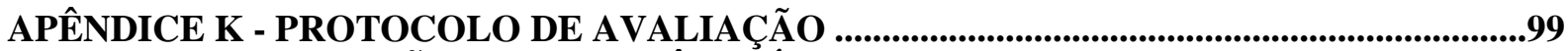

ANEXO A - APROVAÇÃO DO COMITÊ DE ÉTICA .........................................................107 


\section{INTRODUÇÃO}

O programa de pós-graduação Interunidades em Bioengenharia é composto pela Escola de Engenharia de São Carlos, Faculdade de Medicina de Ribeirão Preto e Instituto de Química de São Carlos. Através da união destes saberes, possui a filosofia de promover o avanço no conhecimento técnico e científico no campo da reabilitação através da integração e da capacitação de profissionais com formação em ciências exatas (engenharia, física, química, matemática), em ciências biológicas (biólogos) ou da saúde (médicos, fisioterapeutas, terapeutas ocupacionais, fonoaudiólogos, farmacêuticos) para a solução de problemas relacionados à saúde.

$\mathrm{Na}$ prática clínica, através da atuação como terapeuta ocupacional do Centro de Reabilitação do Hospital das Clínicas HCFMRP - USP foi possível a aproximação com sujeitos que apresentam sequelas físicas, devido a patologias diversas, sendo que a busca de conhecimentos e capacitação especializada foram de extrema importância.

A associação da vivência clínica da reabilitação física com a busca de soluções para potencializar os resultados foi possível através da realização deste projeto, iniciado em 2015 com a parceria da equipe do Laboratório de Reabilitação Robótica da EESC, coordenado pelo prof. Dr. Glauco Augusto de Paula Caurin, que tem como uma de suas linhas de pesquisa o desenvolvimento de equipamentos robóticos na reabilitação. Assim, os membros do Laboratório já haviam desenvolvido um Robô - MOREw, porém necessitava seu aprimoramento e realização de testes clínicos, com sujeitos que possuem alteração no movimento dos membros superiores para o uso em centros de saúde.

\subsection{Histórico de desenvolvimento do robô MOREw}

A aplicação e uso da robótica na reabilitação física pela EESC teve início no ano de 2010, em estudos voltados ao tratamento pós-fratura da extremidade distal do rádio através da criação de um robô que auxiliasse no processo de reabilitação. A este robô foi pensado o nome de MOREw, na junção das palavras movimento e reabilitação, resultando na palavra MORE, que em inglês significa "mais", sendo assim um recurso a mais na recuperação dos pacientes. A letra w ao final referencia-se à palavra wrist, que em inglês seria a tradução de pulso/punho. 
A figura abaixo, publicada pelo jornal A Folha de São Paulo ${ }^{1}$ ilustra bem o conceito deste primeiro protótipo.

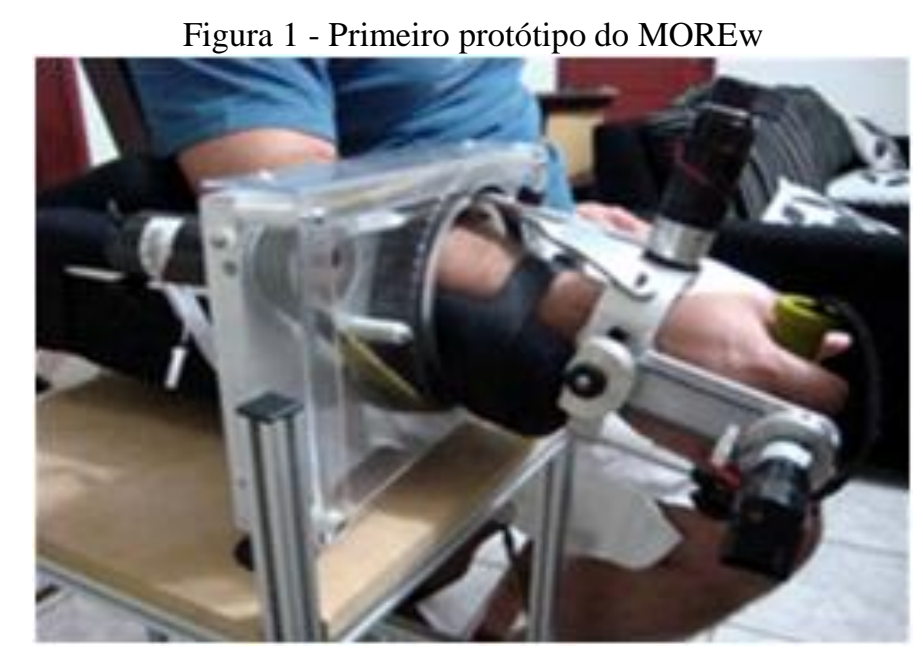

Fonte: A Folha de São Paulo, 2011.

Naquele momento, o intuito era associar o uso do robô às sequências de movimentos que deveriam ser executadas durante o processo de reabilitação. Assim, através de um jogo de computador (Figura 2) o equipamento robótico auxiliava a realização, de forma automática e com repetições necessárias, os movimentos necessários para o tratamento. $\mathrm{O}$ jogo, para esta finalidade, possui um papel motivador frente ao grande número de exercícios que precisam ser repetidos pelo paciente e também caracteriza-se por aliviar a carga de trabalho do terapeuta, que avalia a necessidade e configura, no jogo, os parâmetros necessários e adequados a cada paciente, como amplitude de movimento, níveis de dificuldade, etc. (ANDRADE et al., 2016).

Nesta versão inicial o sistema era capaz de operar com 3 graus de liberdade do punho: movimentos de flexão-extensão, pronação-supinação e desvio radial e ulnar.

Uma das principais contribuições alcançadas com este primeiro projeto foi a capacidade do robô de capturar dados referentes às grandezas cinemáticas (amplitude de movimento, velocidade, aceleração) e dinâmicas (esforços) dos referidos movimentos de forma mais precisa, com maior confiabilidade (ANDRADE et al., 2014).

\footnotetext{
${ }^{1}$ Quarta-feira, 20 de julho de 2011 - Caderno Cotidiano - Saúde, página C8 - de autoria de MARIANA VERSOLATO
} 
Figura 2 - Ilustração do uso do robô na prática clínica

\section{TERAPEUTA ROBÓTICO}

Como funciona a fisioterapia

com auxílio de computadores

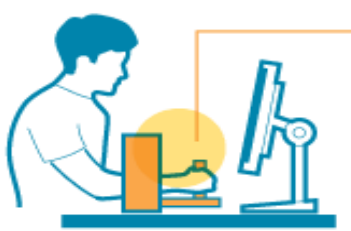

1 paciente coloca o vo robótico e, com um joystick, executa jogos de videogame

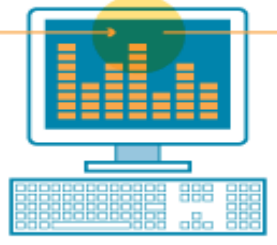

2 Sensores captam os movimentos do paciente e transmitem as informaçōes para um computador

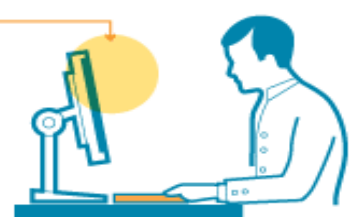

3 O fisioterapeuta vê dados como a evolução da extensāo do movimento do punho e, assim, pode analisar se esse movimento melhorou, piorou ou não apresentou mudanças

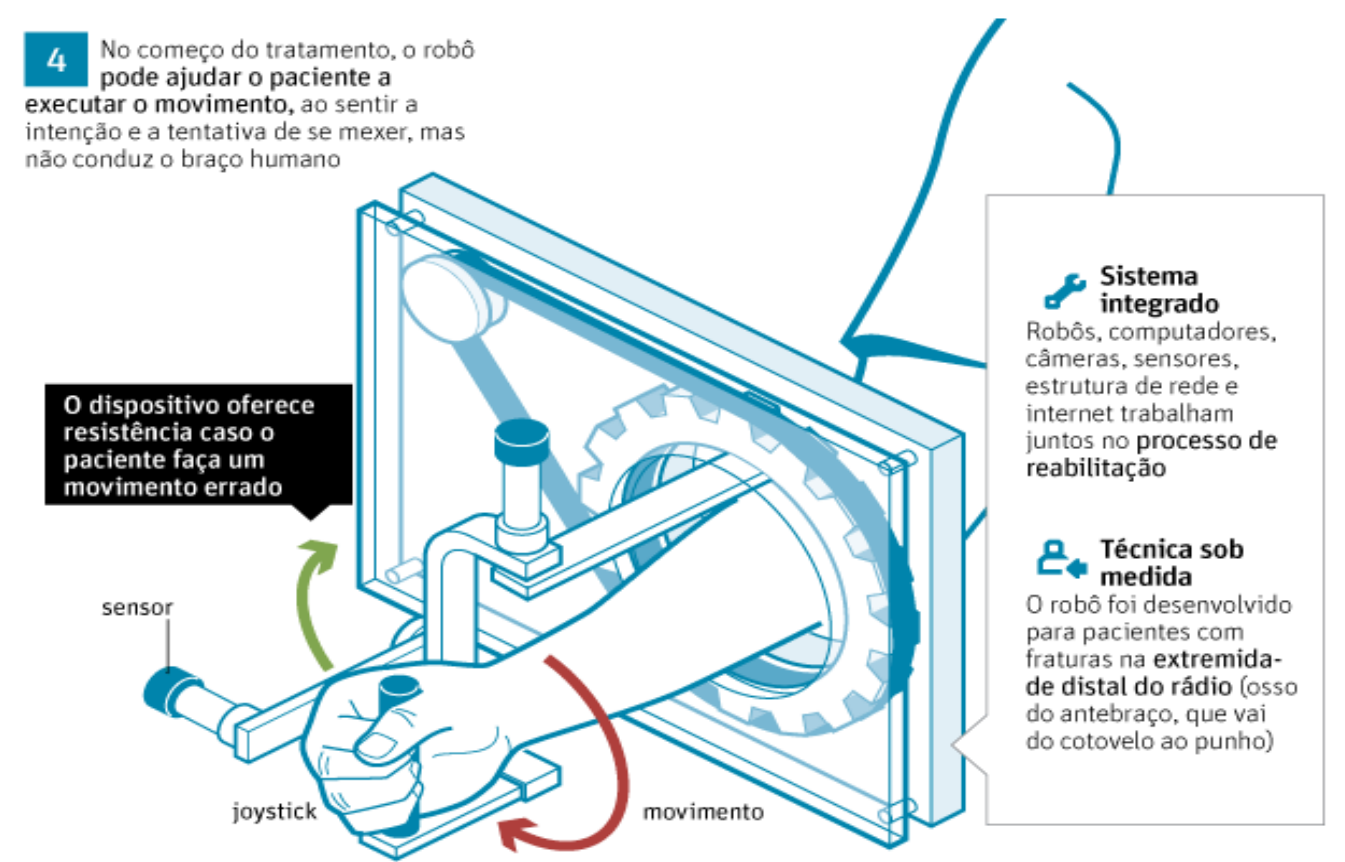

Fonte: A Folha de São Paulo, 2011.

Através das experiências vivenciadas junto aos diferentes profissionais da área da saúde (fisiatras, fisioterapeutas e terapeutas ocupacionais), foi possível a modificação e melhoria do robô para a criação de um novo modelo, mais simples e que fosse capaz de atender os seguintes requisitos:

- Interação mais confiável e confortável com o punho do paciente;

- $\quad$ Alteração de design tornando o acesso à estrutura mais simples e rápida;

- Simplificação do design de forma a melhorar o impacto visual para terapeutas e pacientes;

- Simplificação do mecanismo permitindo o foco dos estudos em aspectos isolados do movimento (ANDRADE, et al, 2014). 
A segunda versão (Figura 3) foi confeccionada utilizando conceitos de software de tempo real e modificações de acordo com o perfil de cada sujeito, com aprimoramento do design visual do jogo de forma a torná-los mais atrativo e moderno. Neste processo foi reduzido para 1 grau de liberdade (flexo/extensão do punho) que devido a conclusões de estudos como apresentados por Krebs et al (2007) relatam que a melhora clínica não se apresenta relevante com mais graus de liberdade.

Figura 3 - Segunda versão do robô MOREw

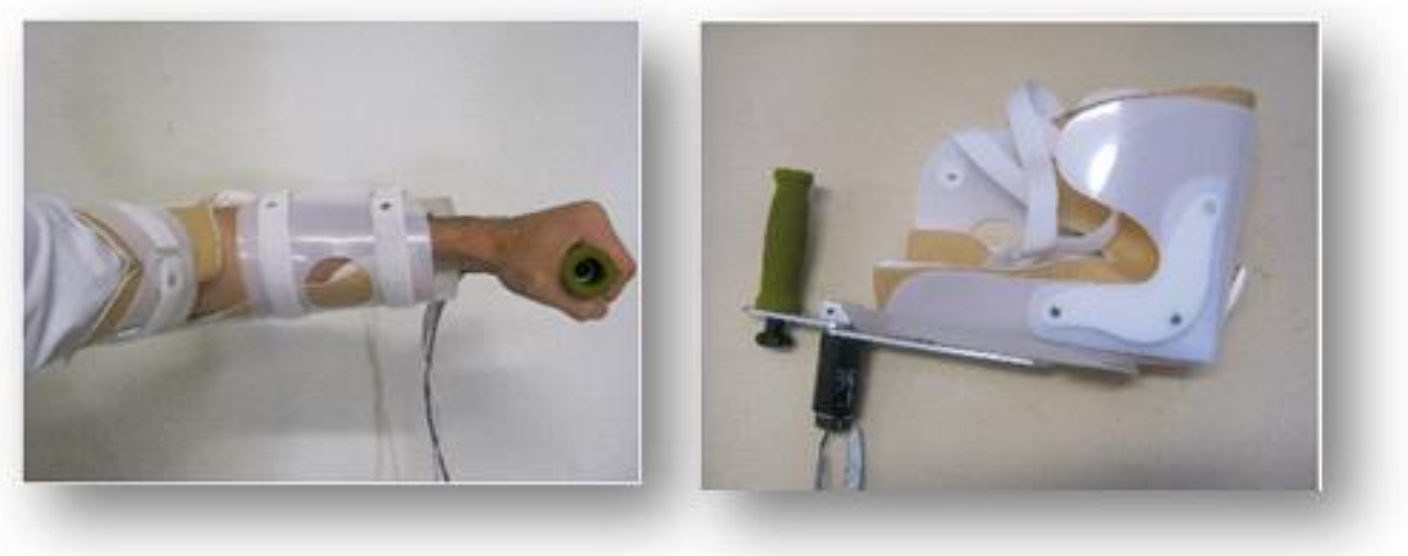

Fonte: ANDRADE et al, 2014.

Testes de bancada realizados com este equipamento robótico comprovaram a sua maior precisão e confiabilidade, tanto em relação ao equipamento mecânico quanto ao software do jogo. Um dos principais requisitos para que haja segurança na interação entre pacientes e robôs é, segundo Krebs (2000), que o robô seja capaz de trabalhar de forma estável e responda às ações do paciente. Também se faz necessário que o mecanismo de transmissão apresente folgas mecânicas muito reduzidas, para a precisão de dados como posição, velocidade e aceleração que impactam na qualidade, confiabilidade e segurança do controle do sistema robótico.

Visando o maior conforto e praticidade para o uso do robô a uma gama diversa de pacientes, optou-se pela modificação do robô para uma $3^{\text {a }}$ versão (Figuras 4 e 5) em que o braço do participante permanece apoiado em uma caixa, sobre a qual está montado o computador para seu funcionamento. Desta forma, o MOREw permanece mais prático para a possibilidade de ser transportado, e também oferece mais conforto em relação ao apoio do antebraço independente da lesão de cada sujeito. Modificações no software utilizado também foram incrementadas, pelos Laboratório de Reabilitação Robótica, para aprimorar o sistema, e serão apresentadas a seguir. 
Figura 4 - Caixa com equipamento robótico

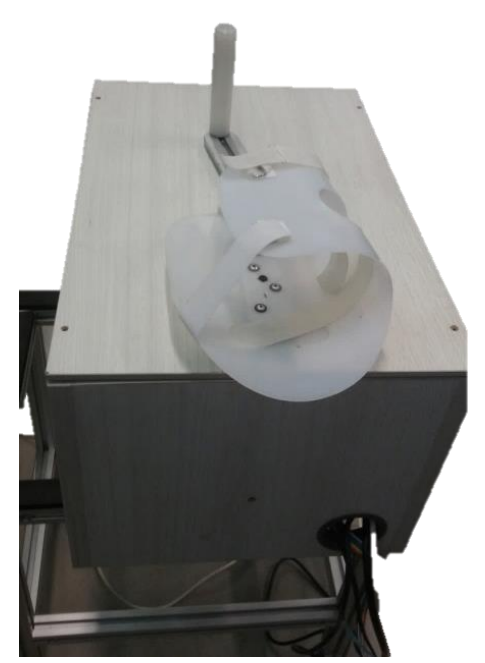

Fonte: Do autor

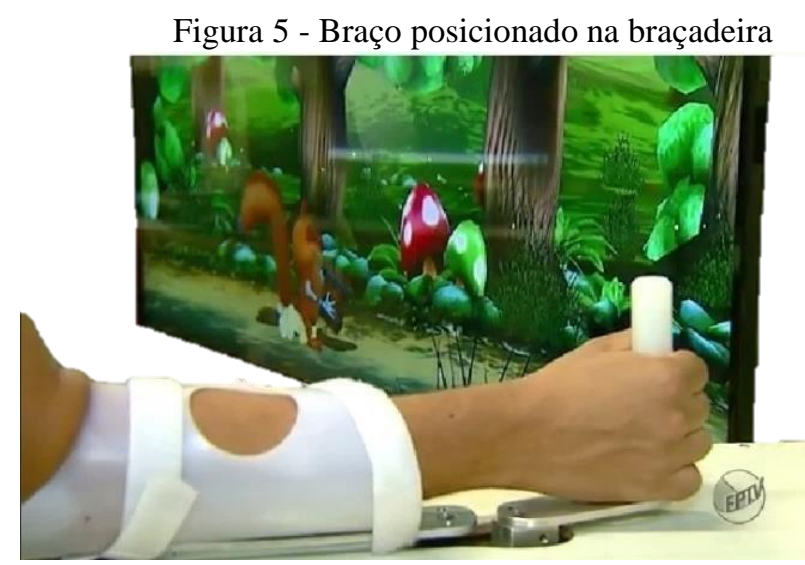

Fonte: Acervo do Projeto.

\subsection{Componentes e funcionamento do robô MOREw}

Com a configuração da $3^{\text {a }}$ versão do robô MOREw o braço do participante permanece fixo à caixa (preso a braçadeira), com adução de ombro, flexão de cotovelo, punho em neutro, realizando preensão palmar na manopla, de forma ergonômica e confortável para o participante (Figura 5).

Para utilizar o robô, o jogador que faz uso deve realizar o jogo The Catcher (Figura 6), também desenvolvido pela Equipe do Laboratório de Reabilitação Robótica. O jogo se passa em uma floresta onde há um esquilo segurando uma cesta. $\mathrm{O}$ objetivo do jogo é direcionar o esquilo para as nozes que cairão das árvores (ao longo de toda a tela, com velocidades variáveis, com a queda de uma noz de cada vez), para conseguir pegar o máximo de nozes possíveis. O direcionamento é realizado através de movimentos de flexão e extensão de punho, e a velocidade e a localização espacial da queda das nozes são influenciadas dependendo do potencial de acertos apresentados. Tal lógica de programação está embasada nos algoritmos genéticos, realizado pelos membros do Laboratório, de acordo com uma variação de velocidade e distância (ANDRADE et al., 2016). Assim, a calibração para a configuração dos dados e do potencial de cada jogador é realizada através da angulação que este realizou, nos movimentos de flexão e extensão de punho, nos primeiros movimentos quando o jogo inicia. Portanto, em todo início de um novo jogo é feito essa calibração e quanto maior a dificuldade que o jogador apresentar durante a calibração, menor a dificuldade imposta pelo jogo. 
Durante a realização do jogo o robô MOREw auxilia o jogador através de um sistema de cooperação que o ajuda na realização do movimento para acerto do alvo. Esta se dá por um auxílio mecânico, com movimentação automática (pelo robô) da manopla, que está presa à mão do jogador. Tal cooperação não é total (não ocorre todas as vezes e o movimento fornecido pela manopla nem sempre chegará ao alvo), para que o jogador não seja auxiliado em todas as vezes, pois invalidaria sua postura ativa para conseguir acertar o alvo.

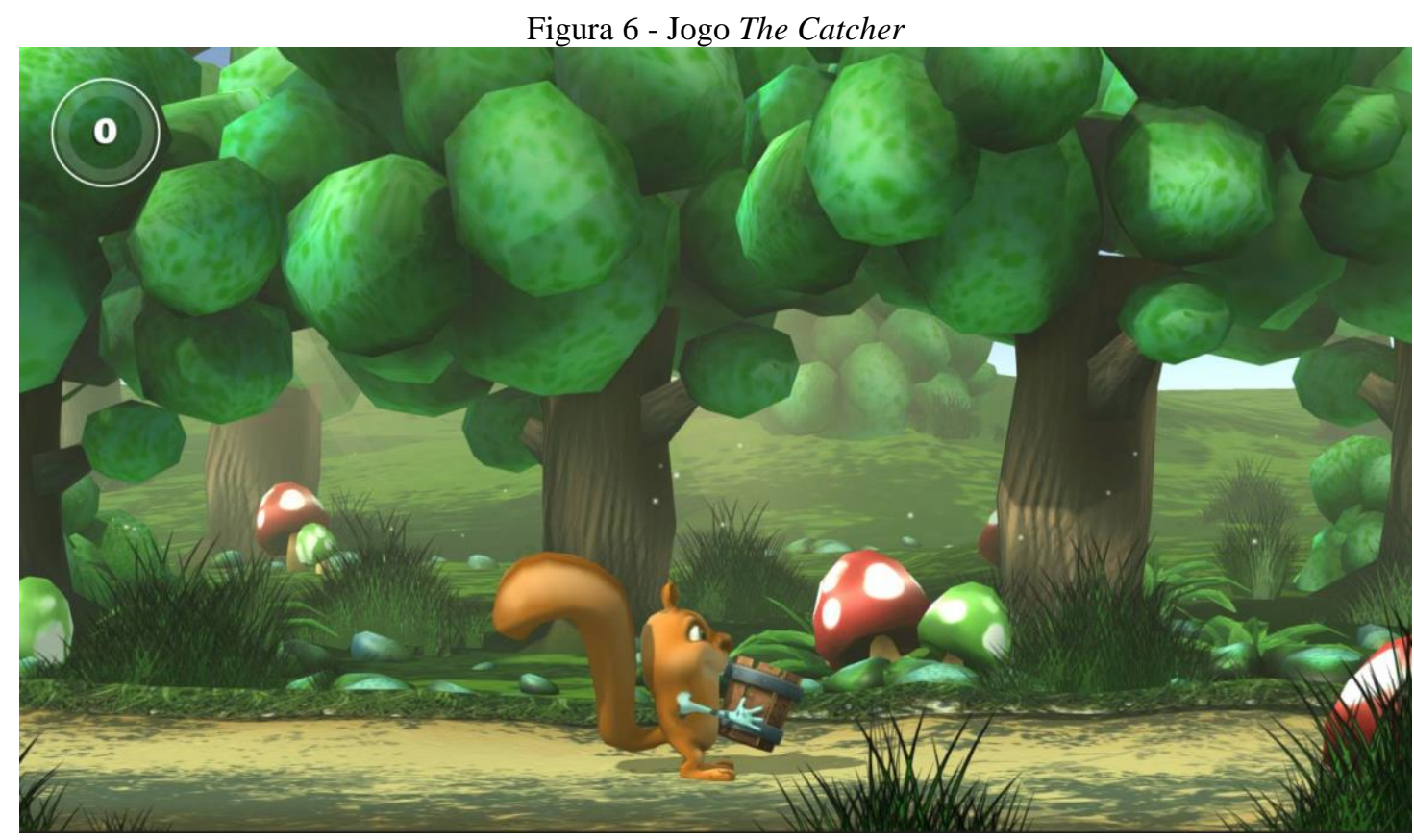

Fonte: ANDRADE, et al, 2016.

Os dados de cada jogo (tempo de jogo, nível de dificuldade, velocidade e pontuação) são armazenados em um banco de dados para as análises e comparações futuras.

A dificuldade imposta pelo jogo é configurada por inteligência artificial adaptativa com base na habilidade do paciente durante as sessões de tratamento (ANDRADE et al., 2016). De acordo com a teoria do fluxo (CSIKSZENTMIHALYI, 1990) o nível de dificuldade do jogo deve equilibrar os desafios propostos com as habilidades do paciente a fim de manter a sua motivação elevada para empenho durante seu uso. Com isso, o algoritmo durante o jogo fará pequenos incrementos de dificuldade para manter os desafios. Nas situações de dificuldades apresentadas, o algoritmo fez decrementos nesta, voltando níveis e facilitando o jogo. Esses procedimentos se fazem necessários para manter o interesse do jogador de acordo com a teoria de fluxo. 
Com as modificações realizadas no robô MOREw, surgiu a necessidade de realização de testes clínicos em sujeitos com comprometimentos nos membros superiores para verificação de seu funcionamento e aplicabilidade.

\subsection{Lesões e Alterações na Funcionalidade}

Como abordamos no estudo pessoas que sofreram Lesão da Medula Espinhal (LME) e Lesão do Plexo Braquial (LPB), é apresentado de forma breve tais lesões e seus principais acometimentos, pois causam grande impacto na movimentação do membro superior bem como na qualidade de vida desses sujeitos, alterando sua funcionalidade (FRANCESCHINI et al., 2012).

\subsubsection{Lesão da medula espinhal}

A lesão medular é definida pela American Spinal Injury Association (ASIA) como sendo uma alteração (diminuição ou perda total) da função motora e/ou sensitiva e/ou anatômica abaixo do nível medular lesado (MAYNARD et al., 1997). Tal situação pode originar-se por diversas causas, sendo a traumática a mais frequente, incluindo os ferimentos por arma de fogo, acidentes automobilísticos, quedas e mergulhos, atos de violência, lesões desportivas, entre outras. A LME vem acompanhada de alterações funcionais quanto ao movimento, sensibilidade, sexualidade e do sistema nervoso autonômico (BRASIL, 2013).

As lesões medulares não-traumáticas correspondem a $20 \%$ dos casos totais. As patologias que causam as referidas lesões são: tumores medulares, fraturas patológicas decorrentes de metástases vertebrais, osteomielite e osteoporose, estenose de canal medular, deformidades graves da coluna, hérnia discal, isquemias, causas infecciosas (mielite transversa, paraparesia espástica) e causas autoimunes (esclerose múltipla) (BRASIL, 2013).

Lee et al. (2013) realizaram um estudo em que apontam que a incidência mundial nas lesões medulares é de 23 casos por milhão de habitantes ou 179.312 casos novos por ano. Ainda são caracterizadas pela maior ocorrência no sexo masculino (4 vezes maior que para o sexo feminino), maior incidência também para jovens, sendo que 50\% dos casos de leões traumáticas encontram-se na faixa etária entre 15-25 anos (SIMÕES, 2008). No Brasil a incidência de lesões medulares traumáticas é de 40 casos novos/ano/milhão de habitantes, ou seja, cerca de 6 a 8 mil casos novos por ano, sendo que destes, $80 \%$ das vítimas são homens e $60 \%$ se encontram entre os 10 e 30 anos de idade (BRASIL, 2013). 
O dano à medula espinhal varia de um acometimento transitório, do qual o paciente recupera-se completamente até uma transecção completa da medula espinhal, acarretando paralisia total dos movimentos e da sensibilidade abaixo do nível da lesão traumática (PORTO, 2000).

Segundo Coura et al (2012), as lesões na medula espinhal podem acarretar alterações motoras, sensitivas, respiratórias, circulatórias, metabólicas, alteração no controle esfincteriano e alterações do tônus muscular. Tal situação pode levar a incapacidades funcionais, tanto para a realização de atividades de vida diária quanto para o trabalho e convívio social. A necessidade de cuidado de terceiros e suporte assistencial de equipe de saúde se faz necessário em todo o processo de recuperação. Assim, o foco de atenção deve ser voltado para a maximização da reabilitação funcional visando a maior independência do sujeito.

O termo paraplegia refere-se à perda de função motora e sensorial nos segmentos torácico, lombar ou sacral (mas não cervical) da medula espinhal, secundária à lesão de elementos neurais no canal espinhal, resultando em alteração do movimento no controle de tronco e/ou membros inferiores. Já a tetraplegia, caracteriza-se quando há prejuízo ou perda de função motora e sensorial nos segmentos cervicais. Resulta em prejuízo da função nos membros superiores, no tronco e membros inferiores (KIRSHBLUM et al., 2011).

Segundo Riberto et al. (2004), pacientes com maior comprometimento motor, ou seja, quanto mais alto o nível da lesão medular, apresentarão menor independência funcional. Assim, sujeitos com níveis mais elevados de dano medular apresentaram maior dependência nas tarefas motoras, tais como habilidade para alimentar-se de forma independente, realização do banho, vestuário, higiene pessoal, vestimenta, transferências (para a cadeira, cama, vaso sanitário), locomoção e, consequentemente, menor pontuação no instrumento Medida de Independência Funcional (MIF). Nota-se que a MIF é um instrumento validado e adaptado para o Brasil por Riberto et al (2004) que se mostra relevante para quantificar o nível de independência funcional.

\subsubsection{Lesão do plexo braquial}

Caracterizada como uma lesão grave que acomete o membro superior, na maioria das vezes ocorre devido a uma tração no ombro de alta energia, levando a alterações temporárias ou permanentes dos movimentos e sensibilidade do membro superior (SILVA; SILVA; GAZZALLE, 2010). 
As lesões do plexo braquial em adultos podem ser devastadoras, frequentemente ocorridas em acidentes como queda de alturas, ferimento por armas, e principalmente por acidentes automobilísticos/motociclístico (KANG; WOLFE, 2011).

Os nervos periféricos realizam a condução nervosa e, quando lesados, podem apresentar alterações na transmissão do estímulo nervoso. Respondem pela sensibilidade e motricidade do membro superior, emergem da coluna cervical entre as vértebras C5 e T1, e são formados após os músculos escalenos, e dividem-se em tronco superior (C5 e C6), médio (C7) e inferior (C8 e T1). O tronco superior é responsável pela movimentação do ombro e cotovelo, o tronco médio pelos músculos extensores e o tronco inferior pela inervação dos flexores de punho e principalmente pela capacidade de preensão. Distalmente à artéria axilar formam-se os nervos musculocutâneo, mediano, radial, axilar e ulnar (DUBUISSON; KLINE, 2002).

As lesões dos nervos periféricos podem ser classificadas quanto a sua localização: supraclavicular, quando acometem a raiz e tronco, e infraclavicular, quando acometem fascículos e ramos terminais (BATISTA; ARAÚJO, 2013). Dessa mesma forma, as lesões supraclaviculares que ocorrem ao nível da raiz dorsal ganglionar são nomeadas como préganglionares ou supra-ganglionares, enquanto as lesões pós-ganglionares ou infra-ganglionares ocorrem distalmente ao gânglio da raiz dorsal (KANG; WOLFE, 2011).

Os sintomas de uma lesão nervosa vão desde a parestesia até atrofia muscular, com perda da sensibilidade e do movimento (SILVA; SILVA; GAZALLE, 2010). Batista e Almeida (2008) reforçam que as lesões no plexo braquial comprometem e dificultam o desempenho das atividades de vida diária, tanto nos aspectos econômicos, sociais e do trabalho.

Kang e Wolfe (2011) afirmam que devido aos graves déficits físicos e psicossociais, a atuação multiprofissional é de extrema importância para a restauração funcional desses sujeitos.

\subsubsection{Alterações da funcionalidade}

As lesões da medula espinhal e do plexo braquial podem alterar o potencial de movimento, sensibilidade e consequentemente a funcionalidade do sujeito para a realização de suas atividades rotineiras.

Franceschini et al. (2012) afirmam que a recuperação funcional do membro superior requer tratamento a longo prazo, a fim de recuperar a máxima independência com a melhor qualidade de vida possível. Diferentes métodos intensivos de reabilitação podem ser utilizados para atingir estes resultados, mas não existe ainda disponível evidência clara afirmando quais técnicas possuem melhores resultados. Pensando na viabilização e na junção de técnicas para 
maior ganho funcional na reabilitação, Sale et al. (2014) reforçam que uma série de dispositivos robóticos têm sido desenvolvidos ao longo da última década para oferecer treinamento sensóriomotor direcionados para pacientes com doenças neurológicas que tem apresentado melhora no desempenho motor do braço nesta população.

No processo de reabilitação os equipamentos robóticos podem atuar como auxiliares nas diferentes ações médico-cirúrgicas; facilitar e estimular processos de recuperação e regeneração natural; e o estimular e maximizar as capacidades residuais. Estas etapas do processo muitas vezes envolvem movimentos repetitivos que devem ser executados diversas vezes a fim de atingir resultados satisfatórios na reabilitação (KREBS et al., 1998).

Segundo Sale et al. (2014), o tratamento de reabilitação do membro superior assistido por robô pode contribuir para aumentar a recuperação motora nos pacientes em reabilitação. Tem apresentado um elevado potencial de melhoria nas condições apresentadas e também como um auxílio para a reabilitação convencional, maximizando os ganhos. 


\section{JUSTIFICATIVA E RELEVÂNCIA DO ESTUDO}

Este estudo se justifica pela existência de poucos equipamentos robóticos nacionais desenvolvidos e sendo utilizados como auxiliares de reabilitação e são necessários estudos tanto em relação ao desenvolvimento de novos equipamentos robóticos com robustez (funcionamento adequado); quanto para a aquisição e armazenamento de dados da reabilitação e sua aplicabilidade em diferentes lesões que acometem o membro superior. A literatura internacional tem seu enfoque em sujeitos que sofreram acidente vascular encefálico (AVE) (BARRECA et al., 2003; KREBS et al., 1998; KWAKKEL et al., 1999; LUM et al., 2002; MASIERO et al., 2007; PRANGE et al., 2006; VOLPE; KREBS; HOGAN, 2001), havendo falta de estudos que abordem outras lesões.

A hipótese é de que o robô MOREw tenha um adequado funcionamento e possa ser utilizado como um recurso auxiliar no processo de reabilitação para lesões neurológicas, forneça dados confiáveis quanto ao funcionamento e quanto a elaboração do banco de dados (aquisição e armazenamento) referentes ao desempenho do sujeito durante o processo terapêutico.

Nota-se que o estudo utiliza o termo funcionamento de acordo com o dicionário Aurélio em que possui o significado de exercer sua função; estar em atividade; ter êxito. Já o conceito aplicabilidade, também segundo o dicionário Aurélio, refere-se à faculdade de aplicação; aplicação prolongada. Dessa forma, tem-se o intuito de verificar se o robô possui funcionamento adequado, de acordo com suas características e composição, e se seu uso pode ser aplicado ao grupo de sujeitos destinados a este trabalho. 


\section{OBJETIVOS}

Tem-se por objetivo geral:

- Verificar a aplicabilidade do robô MOREw na reabilitação de sujeitos com lesão do plexo braquial e lesão na medula espinhal.

Como objetivo específico pretende-se avaliar o funcionamento do robô MOREw quanto ao desempenho mecânico; interface jogo-robô e acessórios. 


\section{MATERIAIS E MÉTODOS}

Trata-se de um estudo quantitativo experimental de corte transversal. Possui caráter descritivo, através da observação, registro e descrição dos fatos. De caráter tecnológico, tem o objetivo de produzir conhecimentos científicos para aplicação prática voltado para a solução de problemas na área da saúde, através da criação de novos produtos e recursos tecnológicos (FONTELLES et al., 2009).

A pesquisa segue os preceitos éticos e foi aprovada pelo Comitê de Ética em Pesquisa do Hospital das Clínicas da Faculdade de Medicina de Ribeirão Preto da USP em 24/11/2015, CAAE 49207915.3.0000.5440, número do parecer 1.335.172 (Anexo A).

O estudo conta com uma equipe de profissionais da área de: artes visuais, computação, desenvolvimento de jogos, mecânica; mecatrônica, robótica e terapia ocupacional.

Para o desenvolvimento a pesquisa utilizou a metodologia de projeto de produto (PAHL; BEITZ, 2004) que são representações filosóficas de uma série de eventos que ocorrem com alguma sequência cronológica e formam um modelo de projeto comum. Existe uma grande variedade de metodologias de produtos e um grande número de modelos estudados, alguns estão divididos em três fases distintas (síntese, análise e avaliação), enquanto outros são divididos em diferentes sub-tarefas, fases e atividades. Os principais autores que estudaram e desenvolveram teorias específicas para esta metodologia são Asimow (1968), Urban e Hauser (1993), Pugh (1995), Kaminski (2000), Back e Forcellini (2003), Baxter (2003), Ulrich e Eppinger (2004) e Pahl e Beitz (2004).

Asimow (1968) define projeto como atividade orientada para atender as necessidades da população, a fim de sanar problemáticas em relação aos fatores tecnológicos e culturais.

A metodologia de escolha deste estudo é definida por Pahl e Beitz (2004) que utilizam como proposta a divisão do projeto em quatro fases, sendo estas: projeto informacional, projeto conceitual, projeto preliminar e projeto detalhado, sendo que as etapas de projeto informacional (reconhecimento da necessidade a fim de levantar um projeto com um equipamento necessário à demanda evidenciada), projeto conceitual (planejamento e desenho do produto) e no projeto preliminar (criação do produto), já foram desenvolvidas anteriormente a esse estudo. Assim, enfoca-se no projeto detalhado através do aprimoramento do produto para sua aplicabilidade e funcionamento, testes em laboratório com o uso do robô MOREw em participantes sem alteração motora no membro superior e com sujeitos com dificuldades motoras.

Para testar e homologar o instrumento foi utilizado o recrutamento de voluntários de forma não probabilística por ‘indivíduos-tipo’ que oferece “riqueza, profundidade e qualidade 
da informação, não a quantidade e nem a padronização" (SAMPIERI; COLLADO; LUCIO, 2006, p. 272), por conveniência.

A metodologia dessa pesquisa está dividida em fase 1 e fase 2. Em cada uma delas está descrito a casuística, local da coleta de dados, critérios de inclusão de exclusão e instrumentos utilizados.

\subsection{Avaliações}

As avaliações utilizadas nesse estudo, estão explicitadas neste item, bem como sua função, uso e objetivos propostos.

\section{- Protocolo verbal Think aloud (Pensar Alto)}

O protocolo verbal "Pensar alto"/"Think aloud" é um instrumento de observações de processo que fornece informações sobre as etapas de processamento individual, tais como verbalizações espontâneas, sequência de movimentos com os olhos, exteriorizando processos mentais durante a solução de uma tarefa (CERVANTES; FUJITA; NARDI, 2003).

Tal mecanismo faz parte de uma técnica introspectiva de Auto-revelação: é um "pensar alto", o pensamento é direto e automaticamente externalizado, os dados obtidos são espontâneos, autênticos sem análise nem edição (COHEN, 1987). Dessa forma, o uso de tal instrumento visa capturar informações ditas durante a aplicação como forma de avaliação das reações evidenciadas, sejam elas relacionadas às dificuldades ou facilidades. Todas as frases e palavras ditas são anotadas (Apêndice A)

\section{- Amplitude de movimento de ombro, cotovelo e punho:}

Segundo Batista et al. (2006), denomina-se amplitude de movimento articular (ADM) a medida que identifica as limitações articulares e a quantidade, medida em graus, de movimento que aquela articulação realiza. Esta medida permite aos profissionais acompanharem de modo quantitativo a eficácia das intervenções terapêuticas durante a reabilitação. O instrumento mais utilizado pelos terapeutas para medir a ADM é o goniômetro universal. Há uma padronização para mensurar a ADM de cada segmento corporal, tanto em relação ao posicionamento do sujeito quanto do goniômetro (NORKIN; WHITE, 1995). 
A amplitude de movimento foi medida com o auxílio do goniômetro universal para os seguintes movimentos ativos: flexão, extensão e abdução do ombro; flexão e extensão de cotovelo; pronação e supinação e flexão e extensão de punho, segundo a sua padronização (NORKIN; WHITE, 1995). A ficha de avaliação de goniometria encontra-se no Apêndice B.

\section{- Medida de força muscular}

Preensão palmar - A força de preensão palmar é caracterizada como a força completa da atividade de força dos dedos e polegar agindo contra a palma da mão, com propósito de transmitir força para um objeto (NAPIER, 1956). O dinamômetro Jamar® tem sido descrito na literatura como o mais eficiente na mensuração da força de preensão palmar. Trata-se de um instrumento hidráulico ou eletrônico bem aceito pelas pesquisas e evidenciado em literatura como um instrumento confiável por ser relativamente simples e fornecer leitura rápida e direta. (MOREIRA et al., 2003).

Segundo a padronização Mathiovetz et al. (1985), quando se utiliza uma única medida, é realizado uma média de três tentativas alternadas (Apêndice $\mathrm{C}$ ).

Teste de Força Manual - $O$ teste de força manual visa mensurar o grau de força de cada grupo muscular. As medidas da força muscular são obtidas utilizando-se o Teste Muscular Manual (TMM) e podem ser classificados segundo a Escala de Força Muscular de 0 a 5 (MILLER; HAHN, 1996).

A Escala de Força Muscular relaciona a força de músculos individuais ou grupos musculares com a sua capacidade de vencer a gravidade ou uma resistência manual (Quadro 1).

Quadro 1 - Grau e resistência aplicada no teste de força manual

\begin{tabular}{|c|l|}
\hline Grau & \multicolumn{1}{|c|}{ Resistência } \\
\hline 5 & Força normal \\
\hline 4 & $\begin{array}{l}\text { Capaz de vencer a força da gravidade contra } \\
\text { uma resistência }\end{array}$ \\
\hline 3 & $\begin{array}{l}\text { Capaz de vencer a força da gravidade sem } \\
\text { resistência }\end{array}$ \\
\hline 2 & $\begin{array}{l}\text { Incapaz de vencer a força da gravidade, mas } \\
\text { capaz de se mover em um plano }\end{array}$ \\
\hline 1 & $\begin{array}{l}\text { Esboço de contração ou contração muscular } \\
\text { discreta sem movimentação articular }\end{array}$ \\
\hline 0 & Paralisia \\
\hline
\end{tabular}

Fonte: MILLER; HAHN, 1996. 
O teste de força manual foi realizado nos seguintes movimentos ativos: flexão, extensão e abdução do ombro; flexão e extensão de cotovelo; pronação e supinação e flexão e extensão de punho. A ficha de avaliação do teste de força manual e preensão palmar encontra-se no Apêndice C.

\section{- Escala Funcional Específica do Paciente}

Utilizou-se a Escala Funcional Específica do Paciente (baseada na Patient-Specific Functional Scale, STRATFORD et al., 1995) que foi traduzida e transculturalmente adaptada para o Brasil (BALBI et al., 2017). Utiliza a escala de Likert para cinco atividades, sendo que três atividades são pré-determinadas previamente pelos pesquisadores (que neste estudo estão relacionadas a alcance de objetos em diferentes distâncias: alcançar copo a uma distância de 10 e $45 \mathrm{~cm}$ a sua frente em uma mesa e $30 \mathrm{~cm}$ na lateral do corpo) e duas atividades cotidianas que o paciente escolherá dentre as atividades importantes que apresenta dificuldade ou é incapaz de realizar como resultado de seu problema e deverá pontuar de 1 a 5, sendo 1 incapaz de realizar e 5 realiza a atividade como antes de acontecer o acidente (lesão) (Apêndice D).

\section{- MIF - Medida de Independência Funcional}

Segundo Riberto et al. (2004), a Medida de Independência Funcional (MIF) é um instrumento de avaliação da incapacidade de pacientes com restrições funcionais de diversas origens. Seu principal objetivo é avaliar de forma quantitativa a carga de cuidados demandados por uma pessoa para a realização de uma série de tarefas motoras e cognitivas de vida diária, ou seja, o quanto ela é dependente ou independente para a realização de atividades. Entre as atividades avaliadas estão as de autocuidados, transferências, locomoção, controle esfincteriano, comunicação e cognição social, que inclui memória, interação social e resolução de problemas. Cada uma dessas atividades é avaliada e recebe uma pontuação que parte de 1 (dependência total) a 7 (independência completa), assim a pontuação total varia de 18 a 126 . Estão descritos dois domínios na MIF, o motor e o cognitivo. Esse instrumento de avaliação funcional foi traduzido para a língua portuguesa no Brasil em 2000 e nessa época foram realizados testes de reprodutibilidade e confiabilidade, que se mostraram em níveis bons para o valor total, bem como nos domínios motor e cognitivo (Apêndice E). 


\section{- Questionário de satisfação/dificuldade com o MOREw}

Utilizando a escala de Likert elaboramos um questionário para avaliação das questões relacionadas a motivação, facilidade de uso do equipamento, conforto, dentre outros. $\mathrm{O}$ questionário possui quatro tipos de respostas para cada pergunta, sendo respondido 1 para muito bom, fácil, confortável; 2 para um pouco bom, fácil, confortável; 3 para um pouco ruim, difícil, desconfortável e 4 para muito ruim, difícil, desconfortável (Apêndice F).

\subsection{Fase 1: adequação do MOREw}

A fase 1 teve por objetivo verificar o funcionamento do robô, adequações e exigências necessárias para seu bom funcionamento. Além disso, verificar erros e necessidades de modificações.

Foi realizada no Laboratório de Reabilitação Robótica da EESC - USP, em sala estruturada para a realização do jogo, de forma individualizada. Participaram dessa fase 10 voluntários da EESC - USP, com os critérios de inclusão: apresentar idade superior a 18 anos, gênero feminino ou masculino, não apresentar sequela neurológica, não apresentar alteração motora ou de sensibilidade no membro superior dominante e aceitar o convite para testar o MOREw. Deveriam participar dos dois testes necessários para esta fase, caso não participassem, seriam excluídos da amostra.

Ao concordarem em participar do estudo, assinaram o TCLE, de acordo com a resolução CNS 466/12 (Apêndice G), ficando livres à não aceitação da participação, sem prejuízo de nenhuma de suas atividades, podendo sair da pesquisa, em qualquer momento, se achassem necessário. Os voluntários que além de se enquadrem nas características já mencionadas, faziam parte da equipe do Laboratório de Reabilitação Robótica da EESC - USP (alunos). A escolha por esses participantes deu-se pelo fato de serem pessoas que trabalham com robótica e que estariam atentos a detalhes importantes para a finalização do robô MOREw.

Para a coleta, o participante permaneceu sentado, em frente à televisão onde o jogo foi ligado e acoplado a braçadeira do robô MOREw no membro dominante. O participante realizou o jogo por duas vezes (duração aproximada de 8 minutos cada jogada, tempo determinado para acerto de 100 alvos) e durante todo o processo o pesquisador anotou as falas, frases e expressões verbalizadas, com utilização do protocolo verbal Think aloud. Logo após o término do jogo o voluntário respondeu ao Questionário de satisfação/dificuldade com o MOREw. O tempo para 
realização de cada coleta foi de aproximadamente 30 minutos. Esse foi considerado o teste 1 da fase 1 da coleta de dados.

Os dados foram analisados, verificados as necessidades de modificações e ajustes e após estas, os mesmos 10 participantes do teste 1, aceitaram participar do teste 2, nas mesmas circunstâncias. Tinha-se por intuito a comparação entre os testes, pelos mesmos participantes, para verificar se os problemas haviam sido sanados.

Para verificar a aplicabilidade do jogo foi realizada a Avaliação Heurística de Jogabilidade (Usabilidade) que segue o modelo criado por Cuperschmid e Hildebrand (2013). É um método de inspeção, que trata da avaliação da interface baseada numa lista de heurísticas pré-estabelecidas. Segundo estes autores, a heurística pode ser entendida como um conjunto de regras e métodos que conduzem à descoberta, à resolução de problemas e ajudam a traçar diretrizes para a concepção deste tipo de produção. São realizadas por especialistas baseados em suas experiências e competências, que por sua vez, examinam o equipamento robótico e realizam um diagnóstico dos problemas ou barreiras que os participantes encontraram durante o uso.

A avaliação heurística exige uma inspeção formal, na qual cada questão é analisada individualmente e ajuda a descobrir questões que não são óbvias sem um método (PINELLE; WONG; STACH, 2008). Este tipo de avaliação produz ótimos resultados, em relação aos problemas diagnosticados, incentivando a busca de soluções. Como a avaliação heurística é subjetiva, Rocha e Baranauskas (2003) recomendam que ela deva ser realizada por um grupo de três a cinco avaliadores. Este estudo contou com três avaliadores. Assim, através da avaliação dos dados fornecidos pelos protocolos Think aloud e Questionário de satisfação/dificuldades com o robô MOREw, foi possível a comparação dos testes 1 e 2 para detectar as falhas do equipamento e, de forma conjunta, a equipe trabalhou na resolução destas para que com os ajustes finalizados, fosse possível a coleta de dados da fase 2.

\subsection{Fase 2: aplicabilidade do MOREw}

\subsubsection{Etapa 1}

O MOREw foi transferido para o Serviço de Terapia Ocupacional do Centro de Reabilitação do HCFMRP-USP (CER) na cidade de Ribeirão Preto - SP., onde foram convidados sujeitos de cada lesão(lesão do plexo braquial e lesão da medula espinhal) que estavam em tratamento no CER no período da coleta de dados, com os critérios de inclusão: 
alteração na movimentação do membro superior (direito e/ou esquerdo), mas com movimentação ativa de ombro e cotovelo, podendo estar ser diminuída tanto em relação a ADM e/ou FM. O movimento ativo de punho e/ou dedos não foi exigência do estudo, porém este movimento deveria ser diminuído (ADM e/ou FM). Deveriam estar em seguimento no próprio serviço (CER), apresentar boa frequência (sem faltas), serem maiores de 18 anos e não apresentarem problemas de compreensão. Não poderiam ter tido contato anterior com o robô MOREw, e, caso surgisse alguma intercorrência ao longo do período da coleta que impossibilitasse a continuidade no estudo, o sujeito deveria realizar a reavaliação final para continuar na amostra, e, caso não fosse possível seria excluído. Foram selecionados por conveniência e, ao concordarem com a participação assinaram o TCLE, de acordo com a resolução CNS 466/12 (Apêndice H).

Enquadraram-se no critério três sujeitos com lesão do plexo braquial e dois com lesão da medula espinhal, que aceitaram participar da pesquisa.

Os sujeitos permaneceram no CER por mais 30 minutos em média, após seu tratamento de reabilitação, para utilizarem o robô e responderam o questionário. Jogaram o MOREw três vezes, na mesma sessão, com duração de aproximadamente 8 minutos cada jogo (tempo médio para acerto de 100 alvos). Para coletar as informações referentes à opinião dos sujeitos quanto ao uso do MOREw, foi utilizado a técnica do "Think aloud" e também responderam ao Questionário de satisfação/dificuldade com o MOREw.

Através da análise do Questionário e opinião do Think Aloud, as necessidades de modificações foram evidenciadas, revistas e realizadas, e após estas, jogaram novamente (três vezes na mesma sessão) para verificar se foram sanadas. Finalizada esta etapa deu-se início a etapa 2.

\subsubsection{Etapa 2}

Nessa etapa, os mesmos sujeitos foram avaliados e passaram por um programa de três meses (uma sessão por semana, totalizando 12 semanas) de intervenção com o robô MOREw. O jogo teve duração aproximada de 8 minutos (tempo determinado para acerto de 100 alvos) e cada dia o sujeito realizou três vezes o mesmo jogo. Ao final de cada dia foi verificado pontuação, nível de dificuldade, tempo realizado e se o sujeito tinha algum apontamento sobre o jogo em relação àquele dia (Think Aloud). As sessões dos jogos foram realizadas nos dias que o sujeito compareceu ao serviço para a reabilitação. 
Os dados foram coletados em sala com ambiente individualizado, com o sujeito sentado em cadeira de rodas (caso fizesse uso) ou em cadeira que respeitasse sua ergonomia.

Realizada avaliação inicial e final (após as 12 semanas de uso do MOREw) com os instrumentos: Questionário satisfação/dificuldade do uso do robô MOREw, avaliação da amplitude de movimento através da goniometria, teste de força de preensão palmar, teste de força muscular manual, Escala Funcional Específica do Paciente) e avaliação da Medida de Independência Funcional (MIF). Também, durante todo o processo a pesquisadora anotou as falas, frases e expressões verbalizadas, com utilização do protocolo verbal Think aloud. A análise dos resultados iniciais e finais foram realizadas de forma comparativa e descritiva. 


\section{RESULTADOS E DISCUSSÃO}

Os resultados serão apresentados segundo as fases do estudo.

\subsection{Fase 1}

Esta fase ocorreu de forma multiprofissional e integrada. A participação conjunta com os diversos profissionais atuantes do Laboratório de Reabilitação Robótica (mestrandos e doutorandos) foi de extrema importância para a adequação do Robô MOREw às necessidades dos participantes que apresentam alterações neuromusculoesqueléticas, mais especificamente a LPB e LME, visando minimizar as possíveis falhas durante a aplicação do robô MOREw para a fase 2 .

Com a comparação das respostas dos testes 1 e 2, relacionados ao Questionário satisfação/dificuldade do uso do robô MOREw e falas do Think Aloud, foi possível verificar os ajustes necessários a serem realizados no robô para viabilizar seu uso, em relação ao seu funcionamento mecânico, ao software e ao conforto de uso do equipamento.

Utilizando a avaliação heurística (ROCHA; BARANAUSKAS, 2003) os ajustes no robô foram baseados em análises referente as demandas apontadas pelos participantes e pelos protocolos utilizados, pensando tanto na acomodação do participante para o uso do robô, como em diversas patologias. As modificações e ajustes necessários serão apresentadas pelos seus itens categorizados.

Outros aspectos levados em consideração foram as possíveis condições que as sequelas trazem e a viabilização do jogo na rotina de um centro de reabilitação. Posteriormente a isso, verificar a opinião de sujeitos que também trabalham na área de desenvolvimento de produtos, fez-se necessário para complementar as adequações.

A coleta de dados da Fase 1, com 10 sujeitos sem comprometimento motor e que seguiam os critérios de inclusão e exclusão, possibilitou verificar que as respostas do questionário de satisfação/dificuldade foram primordiais para verificação dos aspectos positivos e os que necessitavam de alteração e/ou ajustes para facilitação do uso do equipamento.

As informações verbais coletadas sobre o jogo e o equipamento robótico (frases, palavras e considerações) através do protocolo Tkink aloud (Apêndice I) também foram essenciais para auxiliar a equipe nas definições das adequações necessárias ao MOREw e 
apresentaram-se como reforçadores das respostas evidenciadas no questionário satisfação/dificuldade.

Os dados obtidos nos testes 1 e 2 foram apresentados comparativamente segundo os itens categorizados a partir do Questionário de satisfação/dificuldade com o MOREw, que são: orientação oferecidas antes do jogo; fixação do braço na manopla; movimentação da manopla; esforço para atingir o alvo; conforto no uso do equipamento; tempo de realização do jogo; música existente no jogo; segurança para realização do jogo; uso estimulante/motivador; estética/aparência; indicação para outra pessoa; opinião geral do jogo e se jogar causou dor. Associado a comparação dos resultados nos dois testes, será apresentada as modificações e ajustes que foram realizados.

\subsubsection{Orientações fornecidas antes do jogo}

Nesse item foi possível avaliar a qualidade das instruções fornecidas pelo jogo, em tela inicial, com orientação das ações a serem realizadas e o objetivo do jogo (Gráfico 1).

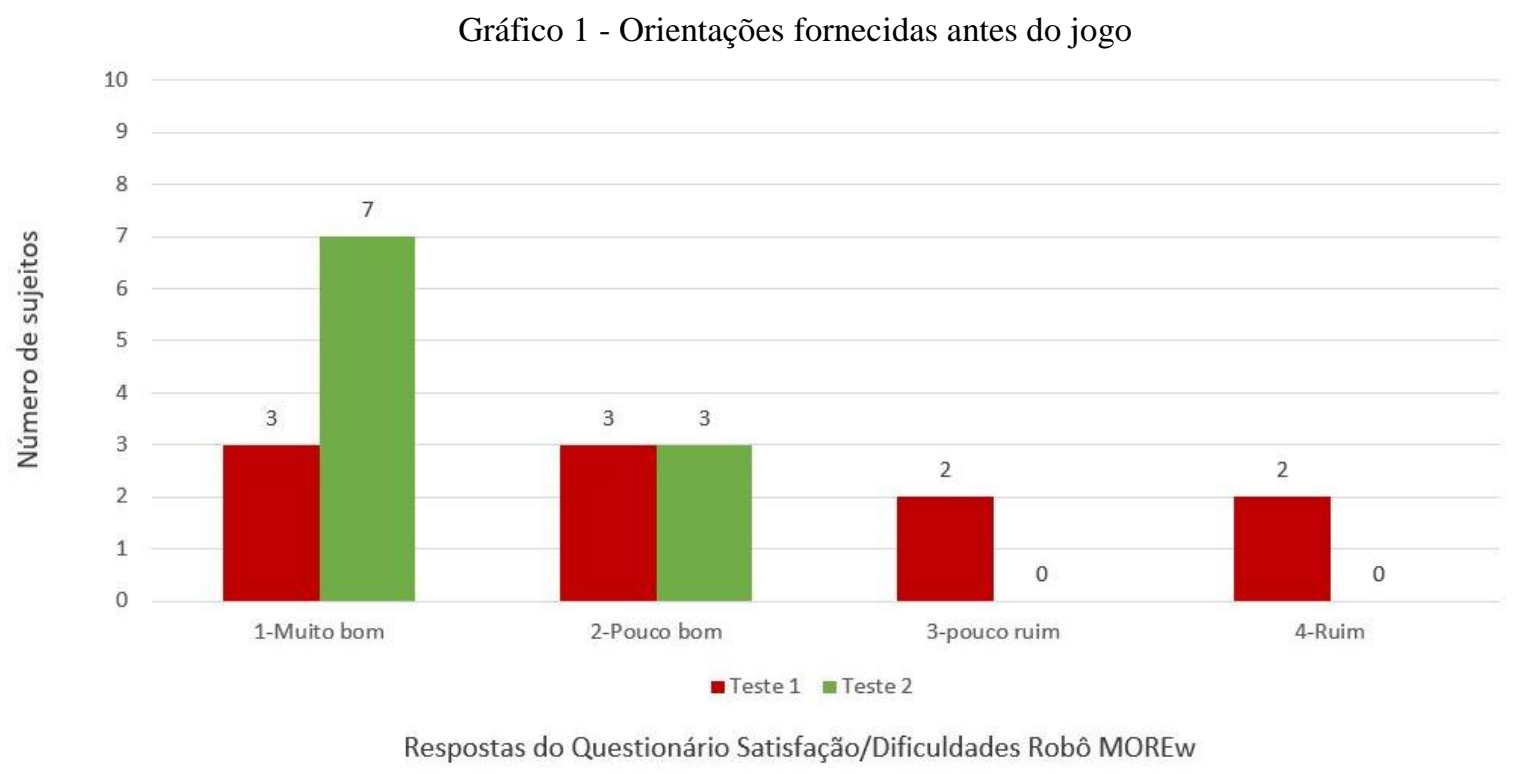

Fonte: Dados da pesquisa.

Através do Gráfico 1 podemos observar que no teste 1,40\% dos participantes pontuaram pouco ruim ou ruim e referiram que as instruções não estavam claras, a mensagem na tela inicial aparecia de forma rápida, sem ser possível o entendimento das instruções. Foi verificada a necessidade de modificação do texto em linguagem mais clara, com maior tempo de permanência na tela e contraste visual para facilitação da leitura. Após as modificações 
realizadas, no teste 2 , foi possível perceber que $100 \%$ consideraram as instruções como bom ou muito bom.

Nota-se que tal questão é de extrema importância para a inserção destes jogos em contextos em que os participantes apresentassem uma variação do nível de escolaridade, visto que a interpretação adequada sobre o funcionamento do jogo pode afetar a execução e sua realização. Assim, orientações simples e de fácil interpretação facilitam o envolvimento com os jogos e sua realização. Para um equipamento ser aceito no mercado é importante conter explicações adequadas, autoexplicativas e que traga confiança ao usuário (PAHL; BEITZ, 2004).

5.1.2. Fixação do braço na manopla

Este item teve o intuito de verificar a satisfação com o posicionamento do braço e sua fixação no equipamento, com respeito a estatura, antropometria e ergonomia para propiciar maior conforto no uso. Foi observada a necessidade de a braçadeira ser regulável e com opções para variações, pois há participantes que referiram maior fixação, outros referiram incômodo ao permanecer "muito apertado" e assim preferiram estar "menos apertado". A possibilidade de ajuste traz maior conforto e melhor posicionamento.

Vale ressaltar que quanto maior a fixação do braço à manopla, maior isolamento da movimentação do punho para a realização do movimento de flexão e extensão no jogo, evitando possíveis compensações de movimento com cotovelo e o ombro.

O Gráfico 2 traz a opinião em relação à fixação do antebraço.

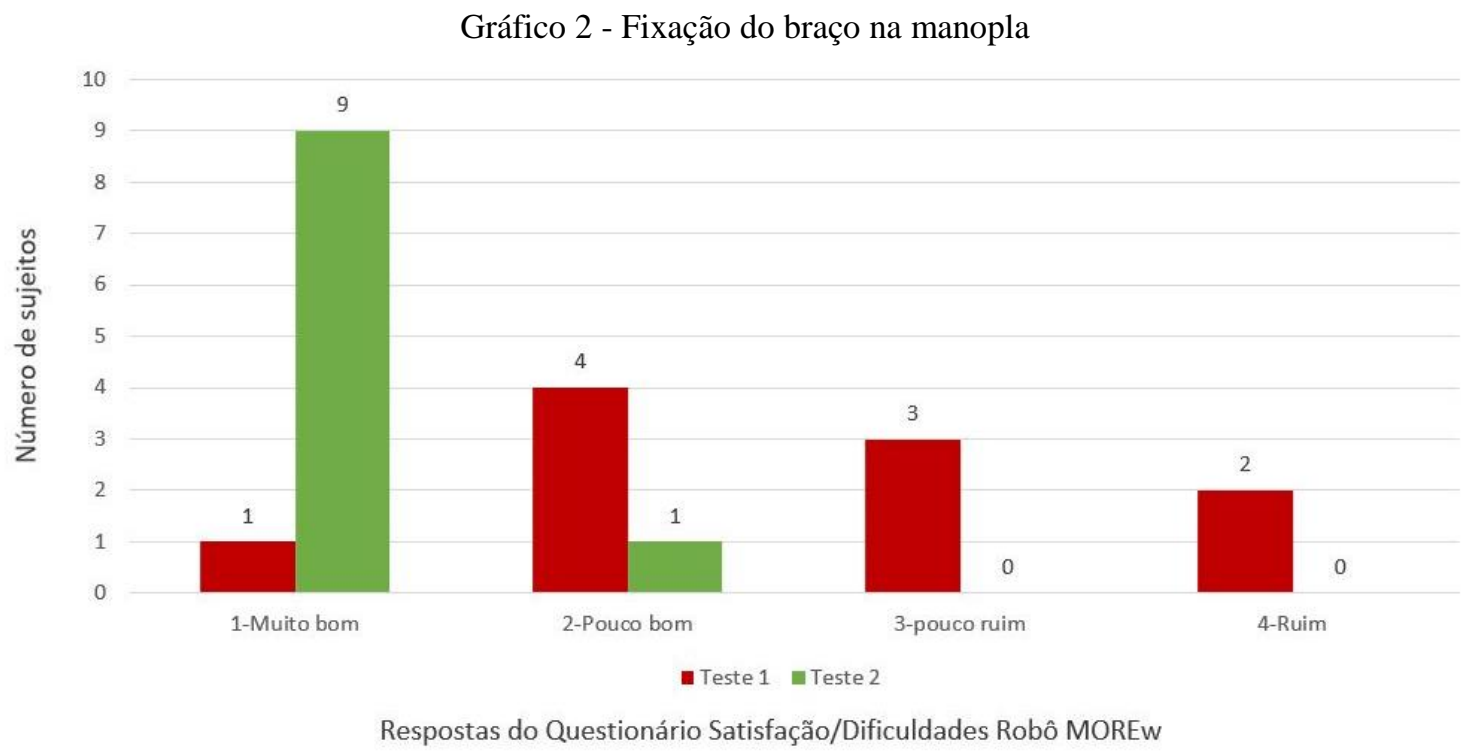

Fonte: Dados da pesquisa. 
No teste $1,50 \%$ dos participantes referiram que a fixação do braço estava pouco ruim ou ruim, sendo que a queixa principal referia-se ao material utilizado - tipo de polímero, que por suas características de dureza e pouca maleabilidade, não forneciam boa fixação do braço na manopla (Figura 7). Junto a isso, pelo protocolo Think aloud, foi possível perceber que $40 \%$ verbalizaram frases e palavras referindo insatisfação com o apoio do braço.

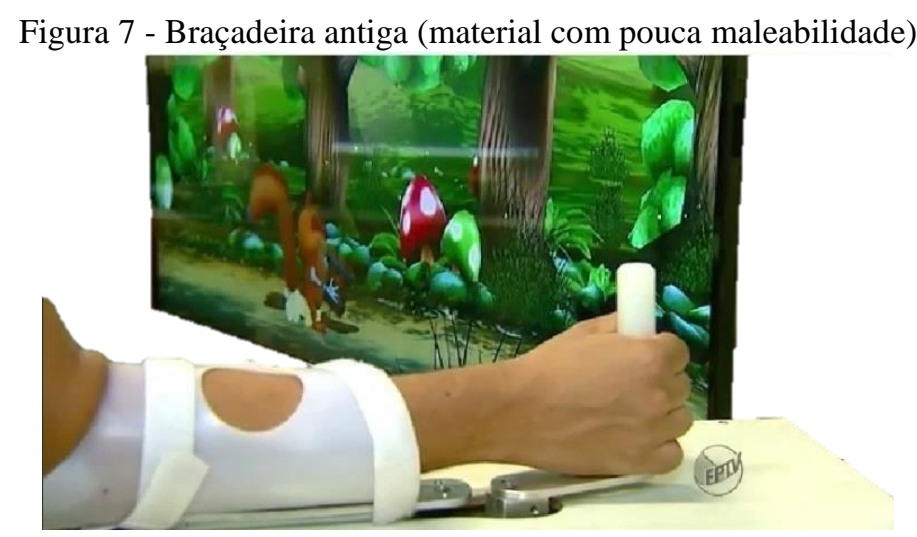

Fonte: Acervo do Projeto.

Para o teste 2, a fixação do braço na manopla foi modificada, utilizando tecido automotivo, associado a uma base rígida confeccionada em termoplástico de baixa temperatura que fornecem resistência, boa fixação e ao mesmo tempo conforto (Figura 8). Tal alteração apresentou um índice de aprovação de $100 \%$ dos participantes verificado no teste 2 .

Figura 8 - Fixação do braço na manopla com tecido de maior conforto

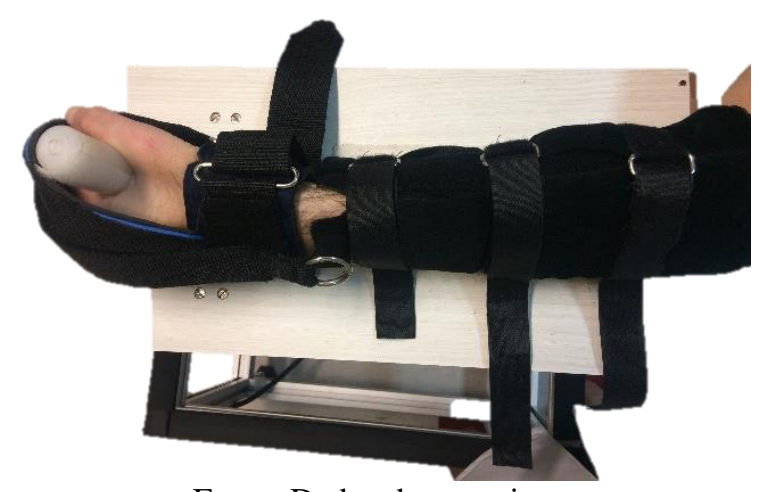

Fonte: Dados da pesquisa.

\subsubsection{Movimentação da manopla}

Este item refere-se à dificuldade/facilidade na movimentação da manopla (Gráfico 3) através da movimentação de flexão e extensão de punho, com o antebraço em posição neutra. 
Este foi realizado de forma ativa pelo sujeito, sendo que, quando necessário, o robô MOREw pode auxiliar/facilitar esse movimento (através da cooperação assistida para atingir o alvo).

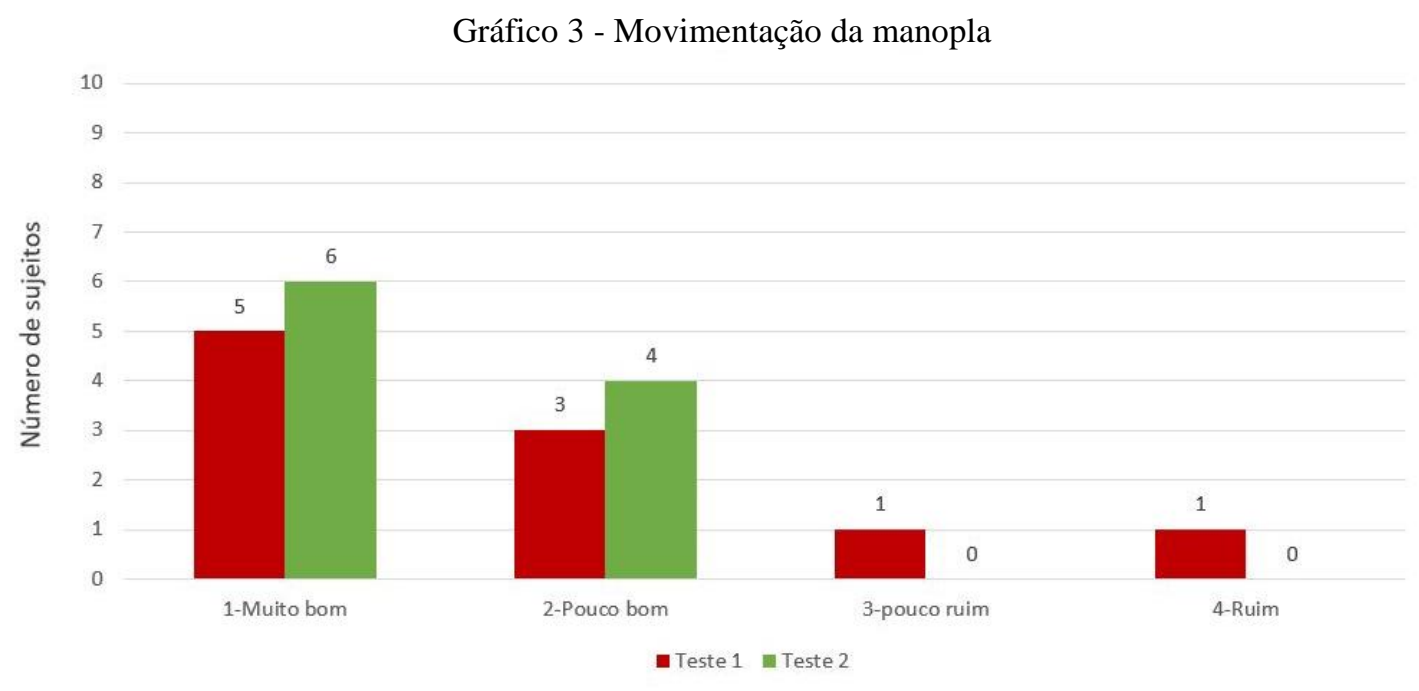

Respostas do Questionário Satisfação/Dificuldades Robô MOREw

Fonte: Dados da pesquisa.

No teste $120 \%$ dos participantes pontuaram pouco ruim ou ruim e referiram sentir resistência e dificuldade ao movimento, gerando dor e fadiga muscular. Ajustes mecânicos internos foram necessários para que não houvesse resistência ao movimento e dificuldade no uso. Verifica-se que após as alterações, no teste 2, 100\% consideraram muito bom ou pouco bom.

Pensando na dificuldade de preensão palmar que os sujeitos da Fase 2 tiveram (visto que possuem alterações do movimento dos membros superiores e dificuldade para preensão de objetos), foi confeccionada uma luva para facilitação da preensão palmar e fixação da mão na manopla, como mostra a Figura 9. Com o uso da luva, mesmo o sujeito não conseguindo realizar ativamente a preensão para segurar a manopla, esta fez a função necessária (manutenção da preensão palmar) para a realização do jogo.

Figura 9 - Luva confeccionada para facilitar a preensão palmar
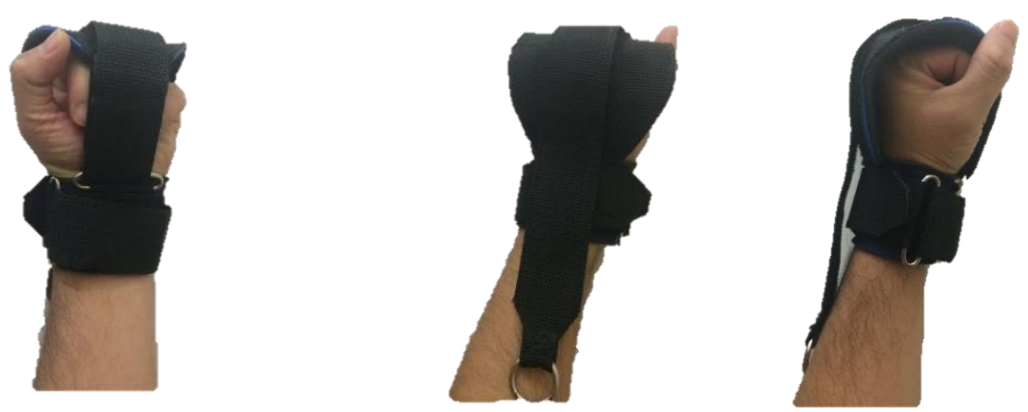

Fonte: Dados da pesquisa. 


\subsubsection{Esforço para atingir o alvo}

Este item propunha-se avaliar a quantidade de esforço necessário para a realização dos movimentos de flexão/extensão de punho necessários para atingir o alvo do jogo, ou seja, as nozes que caiam da árvore (Gráfico 4).

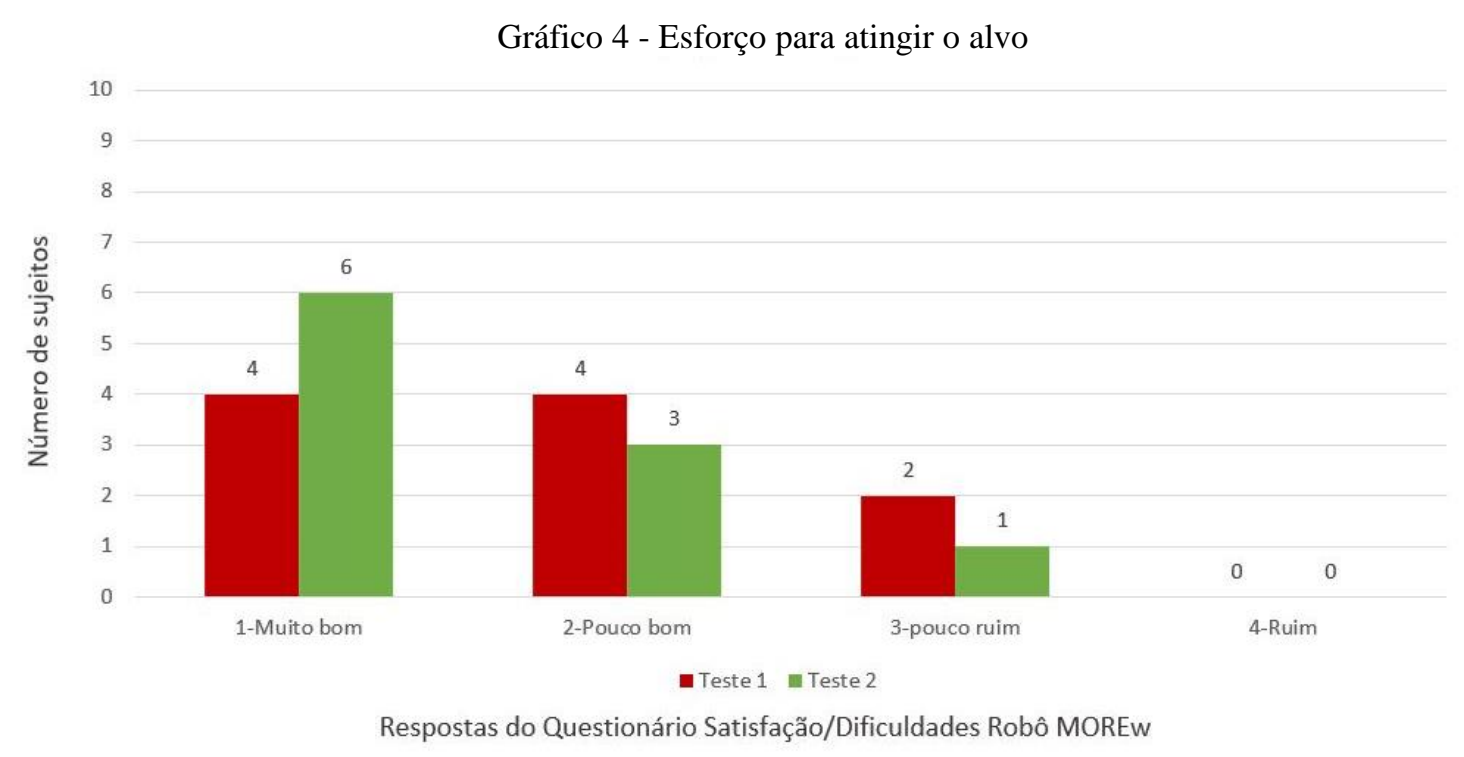

Fonte: Dados da pesquisa.

No teste $1,60 \%$ (que pontuaram pouco bom e pouco ruim) dos participantes referiram que havia a necessidade de grande esforço, com amplitude de movimento exagerada e gerando desconforto para atingir os extremos da tela, direito e esquerdo. Com a repetição de movimento, tal fato acarretava dor no punho e fadiga muscular. Nota-se que tais participantes não tinham nenhuma alteração de movimento ou lesão que justificasse a dificuldade. Ainda, $80 \%$ referiram frases e expressões de descontentamento com a movimentação de flexo-extensão de punho necessária para a realização do jogo, visto que a angulação necessária para atingir o alvo, excedia o limite funcional.

Foram necessários ajustes no algoritmo que determina a localização espacial da queda da noz para melhorar a amplitude de movimento articular funcional e ergonômico (respeitando os limites anatômicos). Após tais modificações, foi verificada satisfação na realização, sendo que apenas um participante pontuou 3 (pouco ruim), pois considerou que estava fácil de atingir o alvo. 
5.1.5. Conforto de uso do equipamento

Neste item tinha-se o intuito de verificar o conforto na utilização do robô MOREw, tanto em relação à ergonomia do equipamento, quanto ao conforto da braçadeira e seu posicionamento (Gráfico 5).

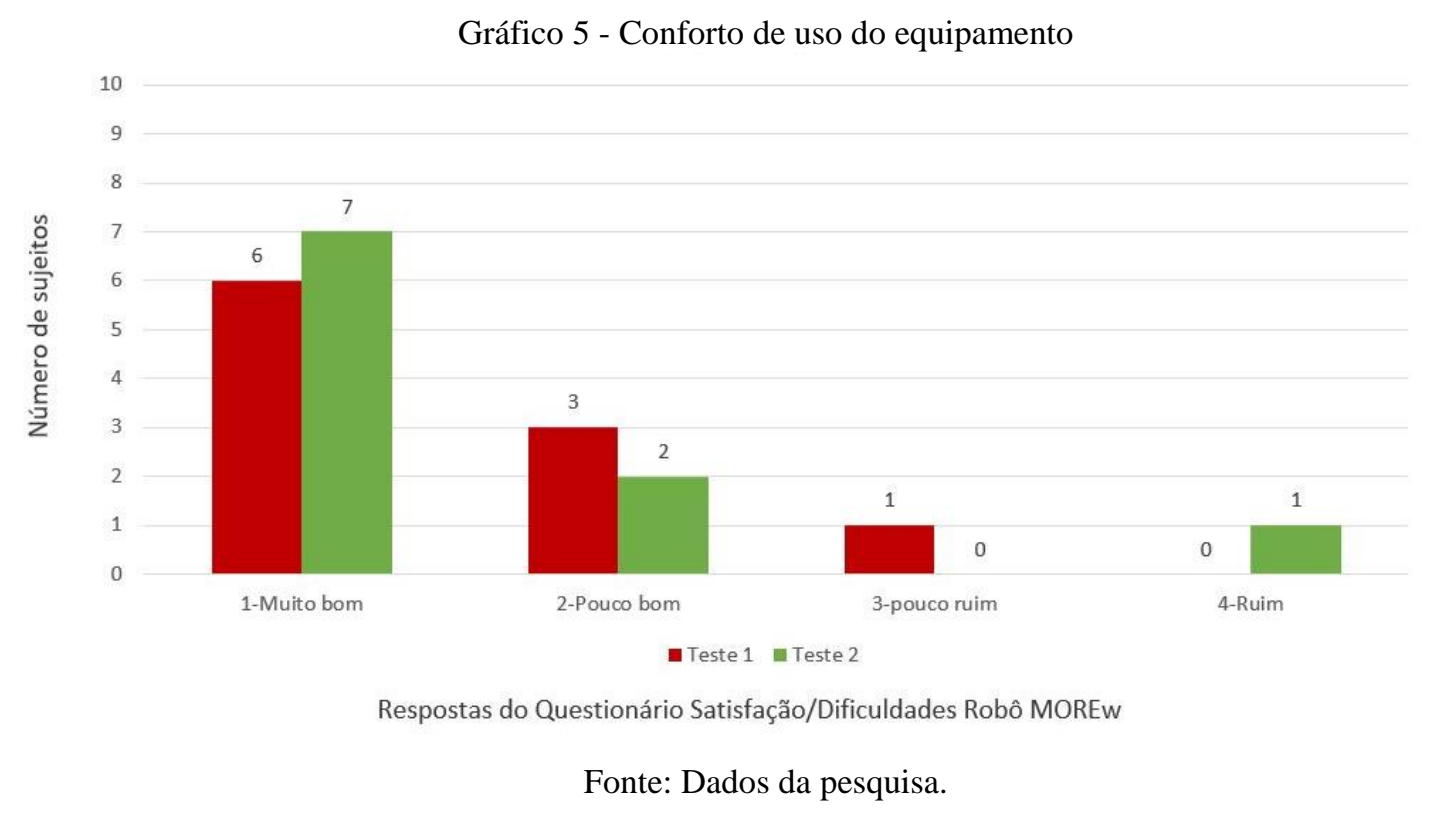

Verifica-se que houve melhora no padrão de resposta dos sujeitos para o teste 2, de acordo com as modificações que foram realizadas (já citadas no item de fixação do braço na manopla), em que $70 \%$ dos sujeitos pontuaram como muito bom. Apenas um participante pontuou ruim a altura do equipamento, pois não favorece participantes de baixa estatura. Houve a necessidade de elaboração de uma mesa com regulagem em altura, que favorecesse indivíduos independente da estatura, como mostra a Figura 10. Porém, de modo geral, tanto no teste 1 quanto no 2, 90\% dos sujeitos pontuaram entre muito bom e pouco bom. 
Figura 10 - Mesa com regulagem de altura para apoio do robô MOREw

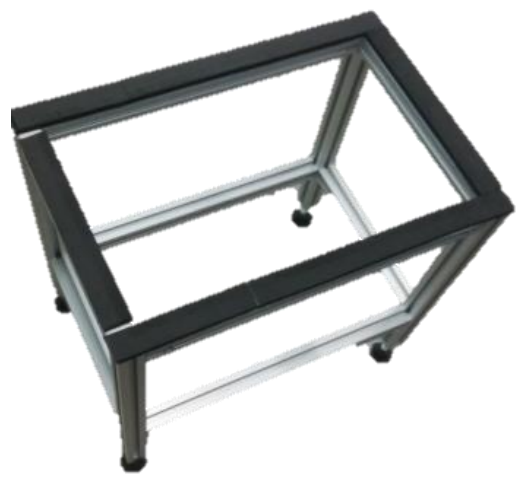

Fonte: Dados da pesquisa.

5.1.6. Tempo de realização do jogo

Este item refere-se ao tempo em que os participantes permaneceram realizando o jogo (Gráfico 6).

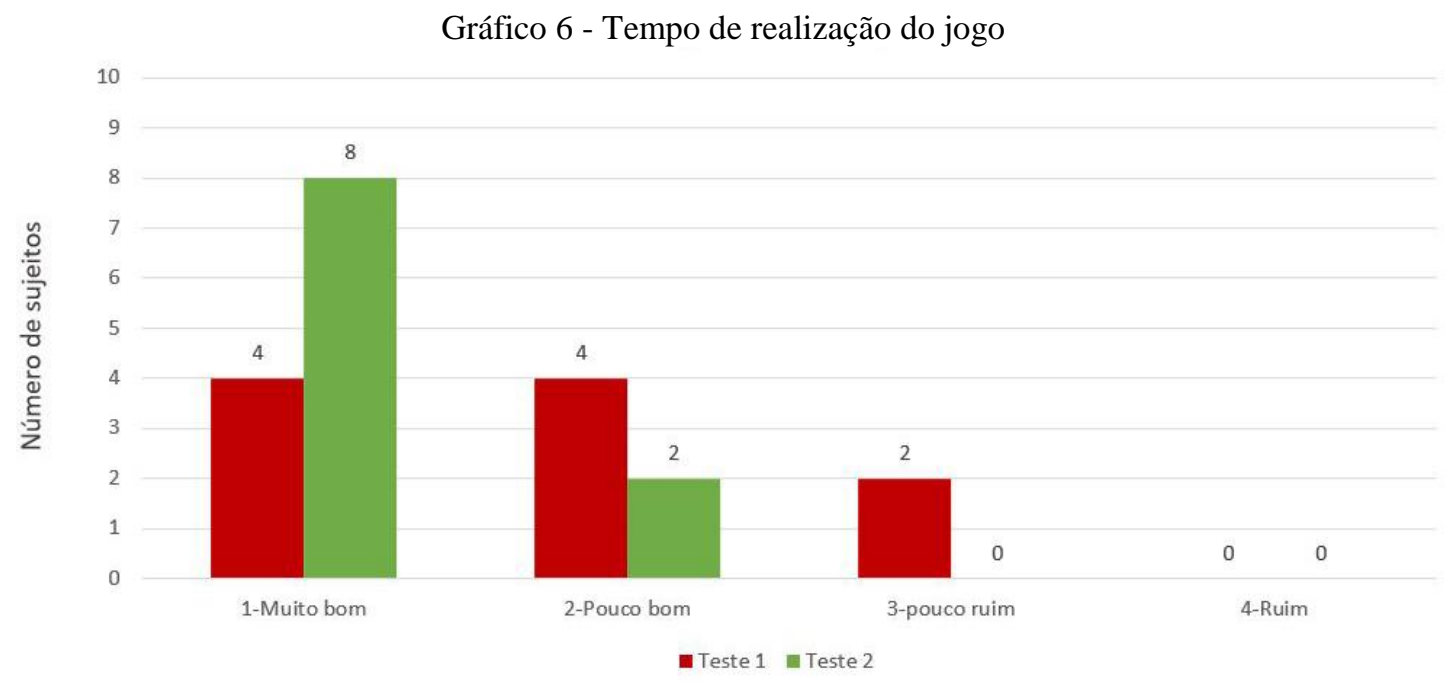

Respostas do Questionário Satisfação/Dificuldades Robô MOREw

Fonte: Dados da pesquisa.

Realizaram duas sessões de 100 alvos, com duração média de 8 minutos cada. Após as modificações estruturais do equipamento, com a melhora da ergonomia, facilidade da movimentação da manopla, houve também maior aceitação dos sujeitos em relação ao tempo. No teste 1 referiram que o tempo gerou dor e desconforto. Com as modificações, percebemos que $100 \%$ pontuaram muito bom ou pouco bom, referindo satisfação com o tempo utilizado, podendo aumentar também o tempo de realização. 


\subsubsection{Música existente no jogo}

Este item tinha-se por intuito avaliar a música existente no jogo (Gráfico 7).

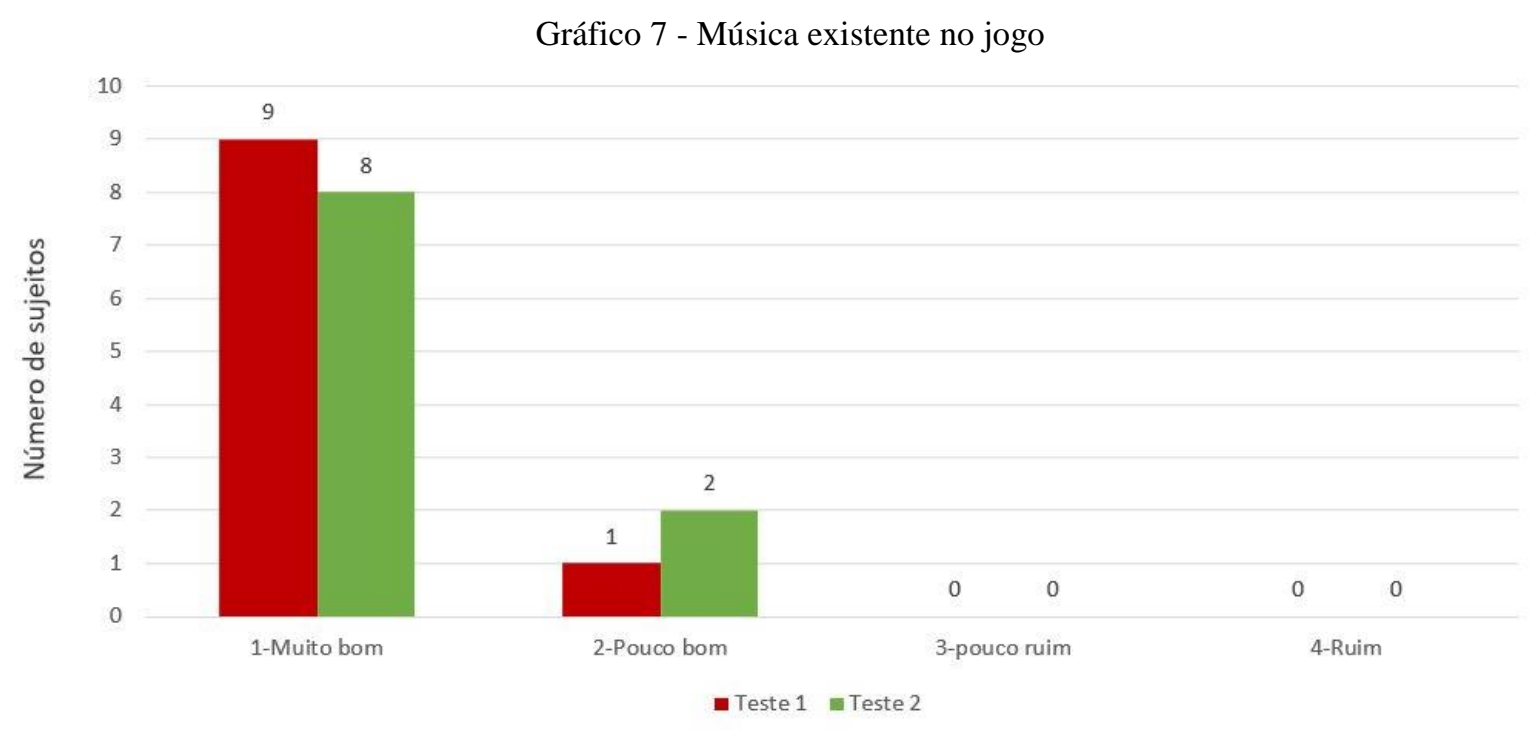

Respostas do Questionário Satisfação/Dificuldades Robô MOREw

Fonte: Dados da pesquisa.

Percebe-se que não houve grandes variações no padrão de resposta do teste 1 para o teste 2 , e não ocorreram modificações na música existente no jogo, sendo que $100 \%$ dos sujeitos pontuaram entre muito bom e pouco bom nos dois testes. Alguns participantes trouxeram relatos de que "a música é interessante, tranquila e lembra jogos de videogames já comercializados" (sic), outros porém trouxeram relatos que " com o uso prolongado do jogo, a música pode ficar cansativa" (sic).

\subsubsection{Segurança para realização do jogo}

Este item torna-se extremamente importante na realização de equipamentos tecnológicos desenvolvidos para a área da saúde, visto que a segurança para realização é um dos quesitos primordiais. Como o equipamento não dispunha de acessórios de segurança durante a realização do teste 1 , houve relatos sobre a importância de colocação destes. Para o teste 2, foi incorporado um botão de emergência para a paralização do jogo de forma instantânea, como mostra a Figura 11. Também, a inserção de um demonstrativo de luzes que informa se o robô está ligado e se está com a cooperação acionada, apresentando os indicativos: 
EPOS, que seria quando o equipamento robótico está ligado; REDE, demonstra quando a rede está ligada (equipamento com jogo) e COOP, seria quando a cooperação está acionada.

Figura 11 - Botão pause de emergência/segurança e caixa de indicativos

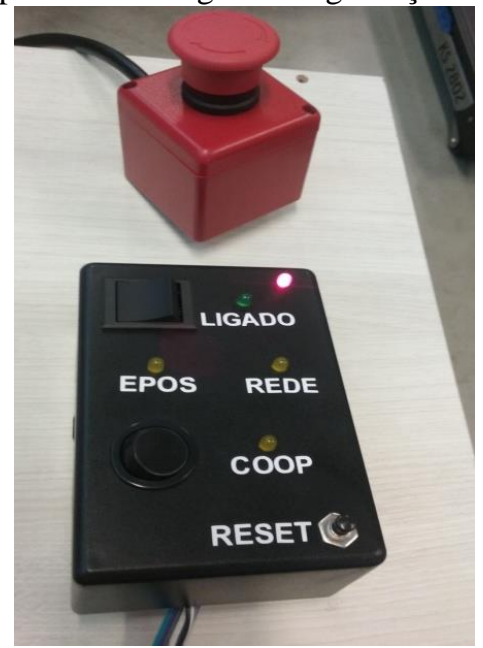

Fonte: Dados da pesquisa.

No gráfico 8 temos a comparação do teste 1 com o teste 2 em relação à segurança que os participantes sentiram em relação ao uso do jogo.

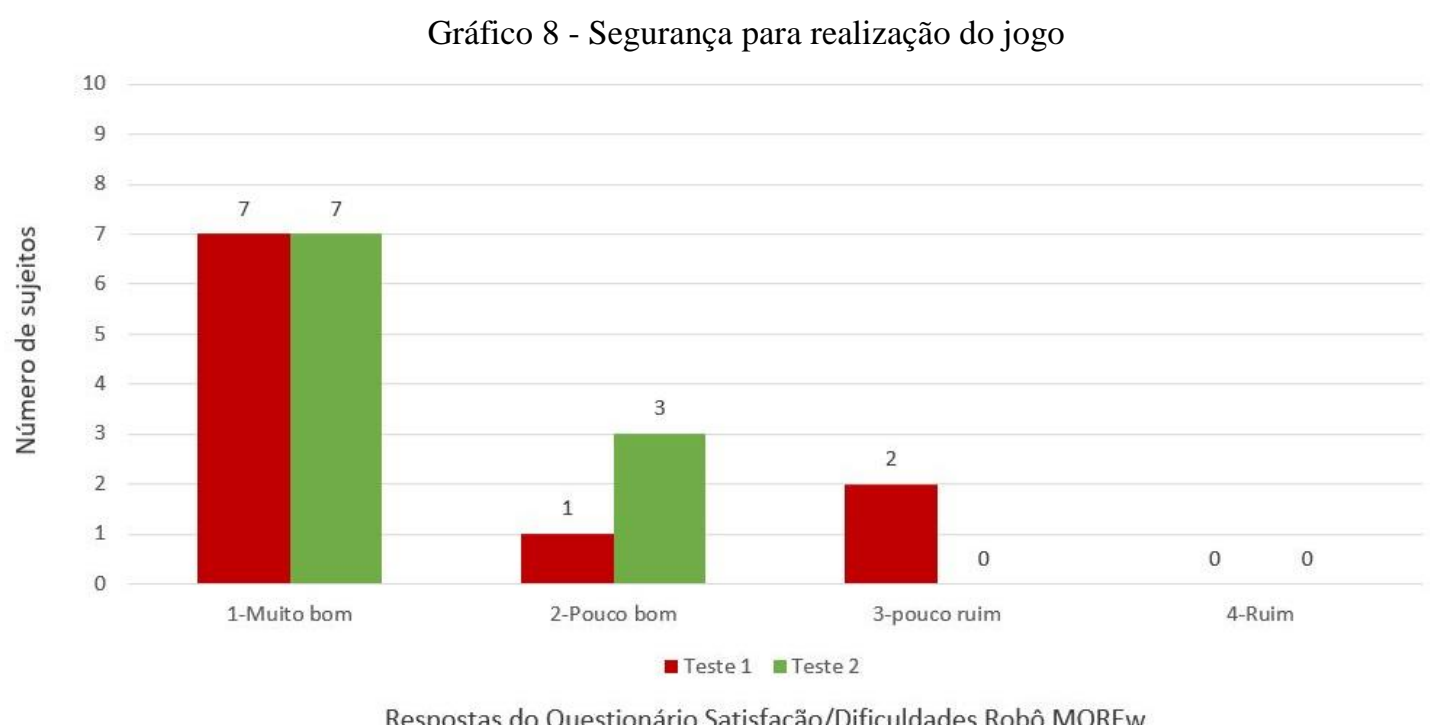

Fonte: Dados da pesquisa.

Nota-se que no teste 1, 20\% dos participantes pontuaram como pouco ruim, visto que não havia sido confeccionado o botão de emergência e a caixa de indicativos quanto ao funcionamento do botão (Gráfico 8). Também pelo protocolo Think aloud, 10\% dos sujeitos verbalizaram a necessidade da existência do botão de emergência. 
Assim, para a realização do teste 2, com a inclusão desses itens, 100\% alegaram satisfação com a modificação e maior segurança no uso (pontuaram entre muito bom e pouco bom).

\subsubsection{Uso estimulante/motivador}

Este item indica se jogo apresentou-se estimulante e motivador para o participante (Gráfico 9).

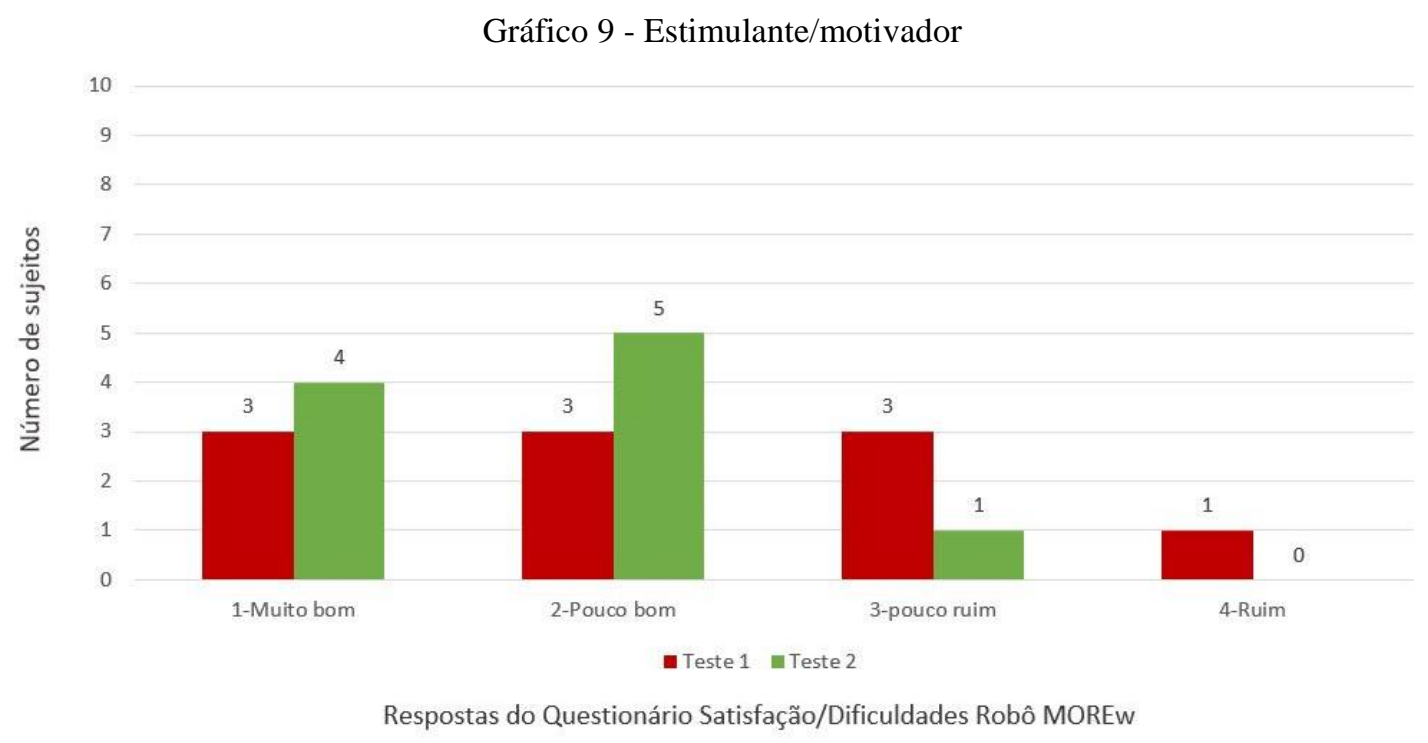

Fonte: Dados da pesquisa.

No protocolo Think aloud do teste 1, 90\% trouxeram a desmotivação ao jogo frente a monotonia que ele apresentava e no Questionário, $40 \%$ dos sujeitos pontuaram como pouco ruim ou ruim. Já no teste 2 , a satisfação frente ao jogo foi de $90 \%$, que pontuaram entre muito bom e pouco bom. Podemos perceber, que após as modificações no algoritmo para queda da noz, com variação da localização espacial e ajustes de tempo, o jogo tornou-se mais dinâmico, motivador e menos monótono.

Apenas um participante no teste 2 pontuou como pouco ruim e referiu que gostaria que o jogo fosse ainda mais dinâmico, porém, como possui o objetivo de uso para sujeitos com dificuldades motoras, entende-se que quanto maior o grau de dificuldade e dinamismo, maior dificuldade na realização, dificultando o uso em contextos de reabilitação. 


\subsubsection{Estética/Aparência}

Este item refere-se à aparência e estética que o equipamento apresenta (Gráfico 10). Notase que o robô está apoiado a uma mesa regulável, na lateral do corpo do participante o que favorece maior ergonomia, posicionamento postural anatômico, porém pode restringir a participação dos sujeitos que não conseguem permanecer em tal postura, seja por falta de controle de tronco, hipertonias, diminuição na amplitude de movimento de ombro, cotovelo ou deformidades, visto que não é portátil e não se adapta a estas necessidades.

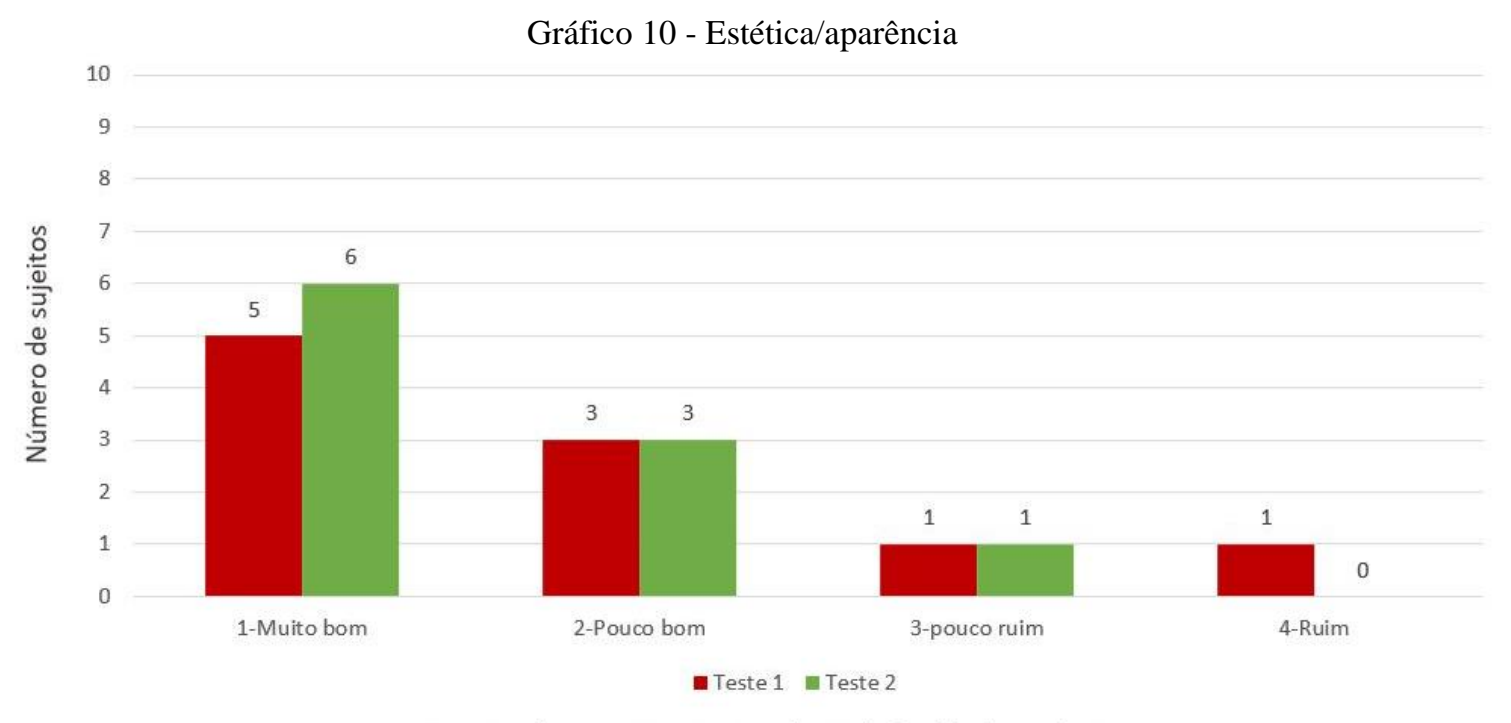

Respostas do Questionário Satisfação/Dificuldades Robô MOREw

Fonte: Dados da pesquisa.

Podemos verificar que $20 \%$ dos participantes que pontuaram pouco ruim e ruim no teste 1 reforçam a importância de o equipamento ser mais leves, de menor tamanho e design mais moderno.

Há a intenção futura de um projeto de melhoria da estética e aparência para o robô MOREw em uma perspectiva moderna e mais amigável. Nesta versão, o robô estaria acoplado no membro superior do participante, e poderia estar ou não apoiado a uma mesa, de acordo com a necessidade (Figura 12). 
Figura 12 - Perspectiva futura do robô MOREw

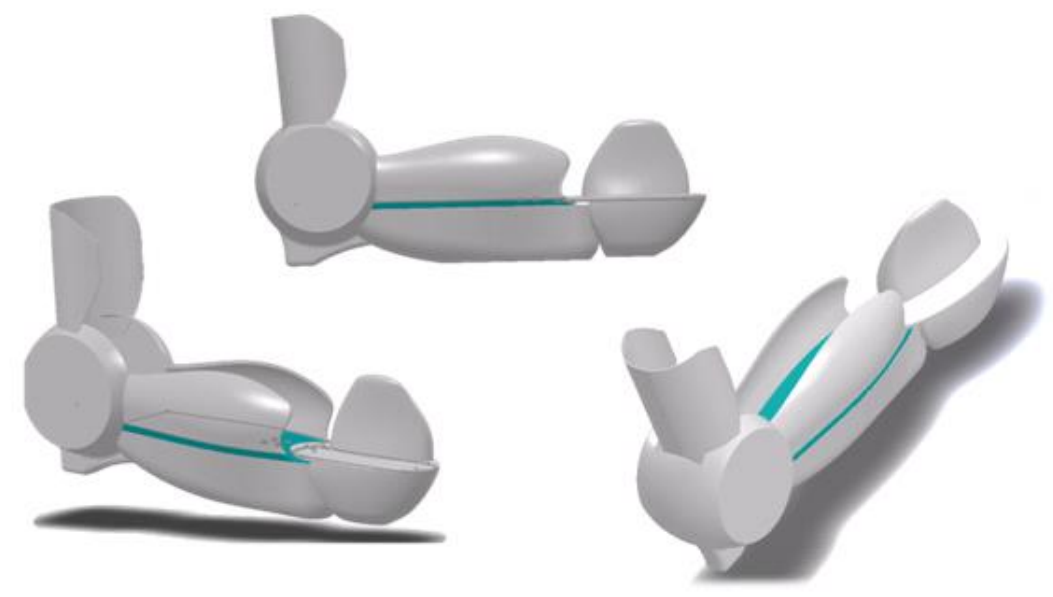

Fonte: Acervo do Projeto.

Quanto ao design do jogo, no protocolo Think aloud, 40\% dos participantes trouxeram a necessidade de ajustes na configuração do esquilo, pois referiram que "estava sensível ao mínimo movimento da manopla, dificultando o acerto do jogo" (sic). Também, 70\% referiram que havia a necessidade de diminuir itens estéticos na tela do jogo, que estavam funcionando como distratores, exemplos: quantidade de árvores, barulho dos passos do esquilo, poeira nos pés do esquilo e queda de folha das árvores. Todas essas modificações foram realizadas para o teste 2 , e os sujeitos não trouxeram novas demandas em relação a estes quesitos, sendo que houve satisfação de $90 \%$ dos sujeitos, que pontuaram entre muito bom e pouco bom, e $10 \%$ que reforçam a importância da modernização e diminuição do tamanho do robô.

\subsubsection{Indicação do uso para outros}

Este item propunha-se verificar se os participantes indicariam ou não o uso do robô MOREw para outras pessoas (Gráfico 11). 
Gráfico 11 - Indicação do uso para outros

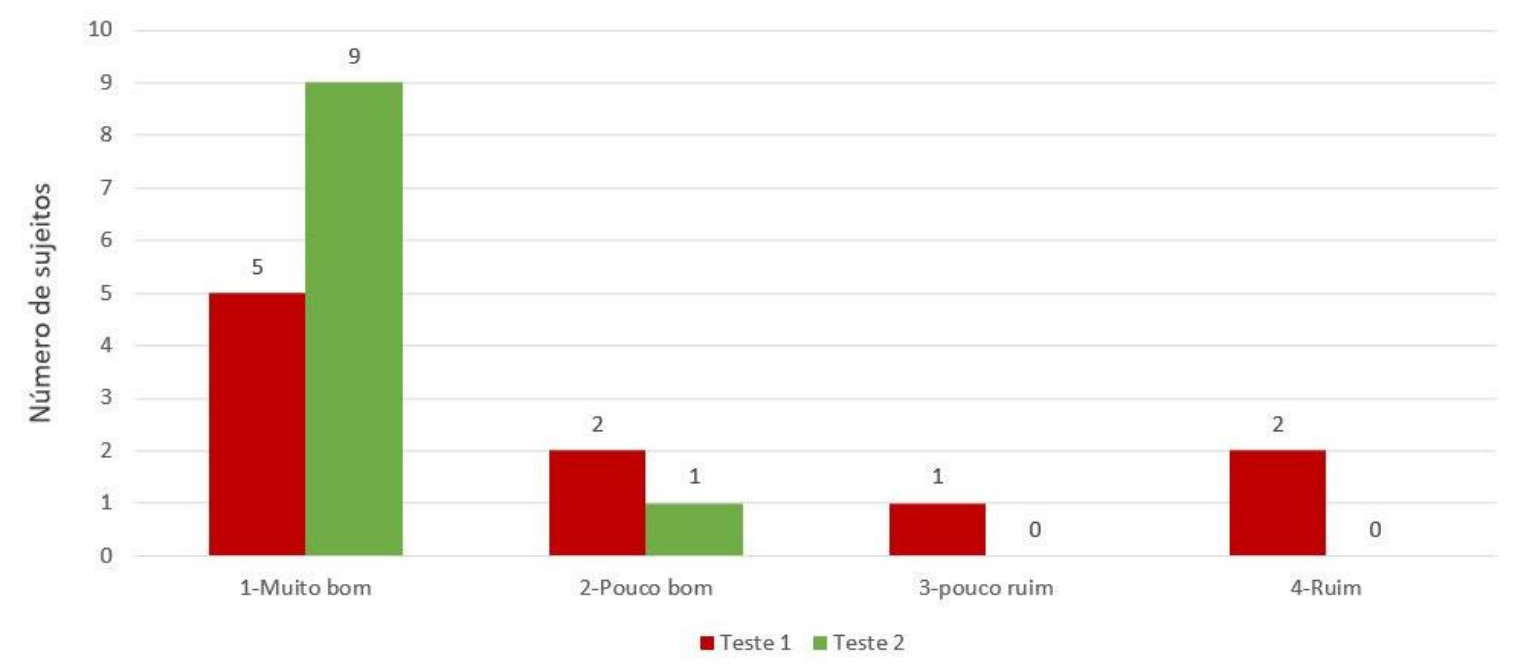

Respostas do Questionário Satisfação/Dificuldades Robô MOREw

Fonte: Dados da pesquisa.

Percebe-se que com relação a indicação do uso para outros, no teste $1,30 \%$ dos participantes pontuaram pouco ruim ou ruim e não indicariam a realização do jogo no robô MOREw para outras pessoas, alegando que o "jogo estava monótono, pouco dinâmico, causava dor e cansaço" (Sic).

Assim, após as modificações que já foram citadas, tanto em relação a ergonomia (braçadeira e mesa) quanto em relação ao jogo, no teste 2 percebe-se que $100 \%$ pontuaram como muito bom e pouco bom e que "indicariam para outra pessoa com certeza" (Sic) (Gráfico $11)$.

\subsubsection{Opinião Geral do jogo}

Este item tinha o intuito de verificar a opinião geral que o participante teve sobre o jogo (Gráfico 12). 
Gráfico 12 - Opinião geral do jogo

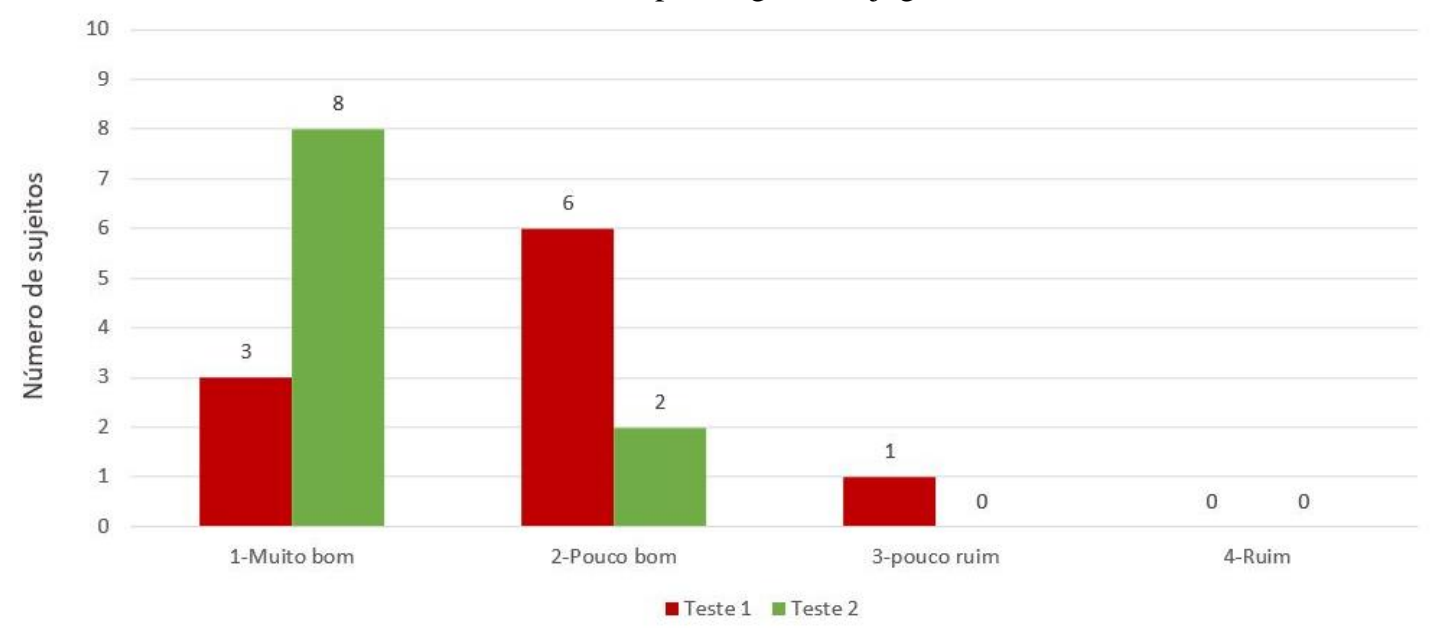

Respostas do Questionário Satisfação/Dificuldades Robô MOREw

Fonte: Dados da pesquisa.

Verificamos uma melhoria nas respostas comparando os testes 1 e 2 na medida que $100 \%$ dos participantes pontuam de muito bom e pouco bom sobre a opinião geral do jogo. Trouxeram relatos como: “com certeza será um recurso interessante para a reabilitação", "animador, estimulante, gostaria de jogar mais" (Sic).

\subsubsection{Presença de dor}

Este item propunha-se realizar a verificação de surgimento de dores com o uso robô (Gráfico 13).

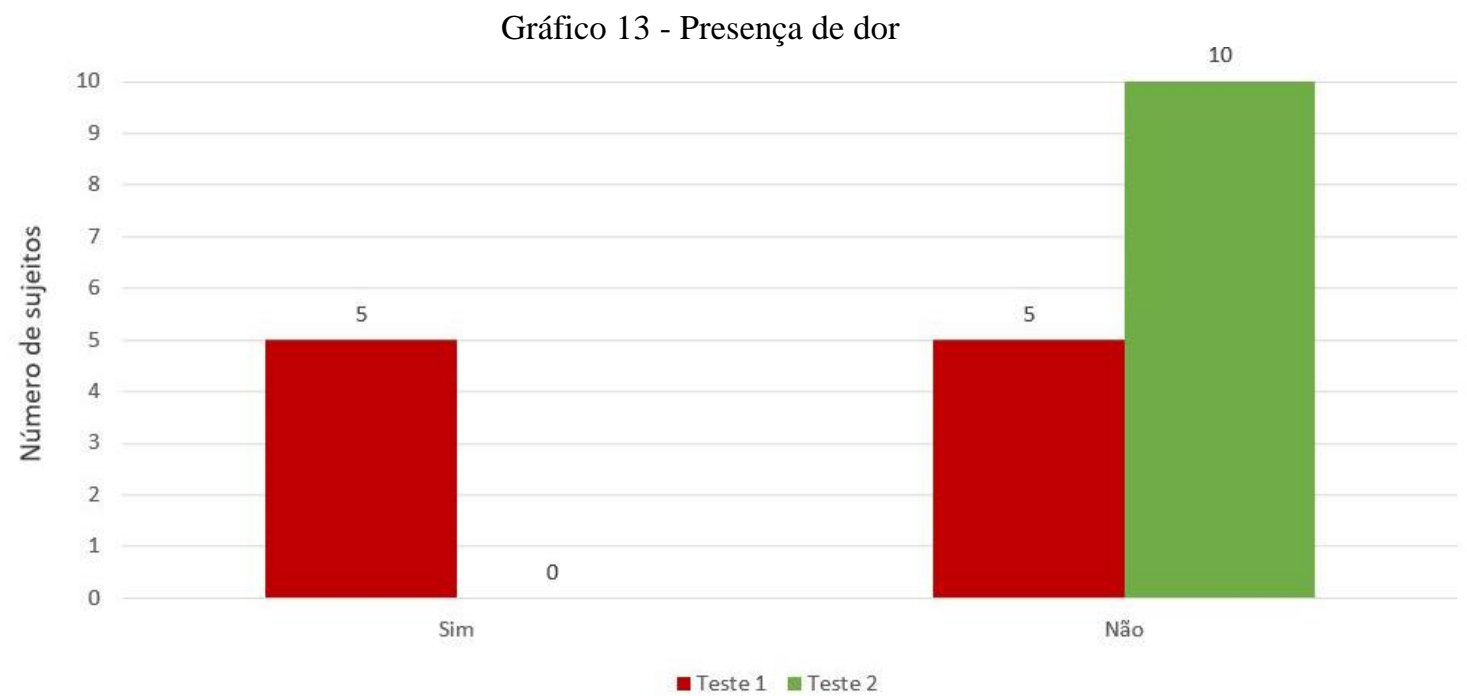

Respostas do Questionário Satisfação/Dificuldades Robô MOREw

Fonte: Dados da pesquisa. 
Percebe-se que no teste 1 metade dos participantes (50\%) referiram que sim, e relataram “dor no punho, fadiga, cansaço" (Sic), e, após as modificações já explicitadas no jogo e no robô, $100 \%$ referiram que não sentiram mais dores, o equipamento ficou confortável e agradável.

Após a conclusão das modificações explicitadas, o robô MOREw estava pronto para a realização da coleta de dados da fase 2, sendo demonstrado o MOREw finalizado na Figura 13.

Figura 13 - Robô MOREw adequado para Fase 2

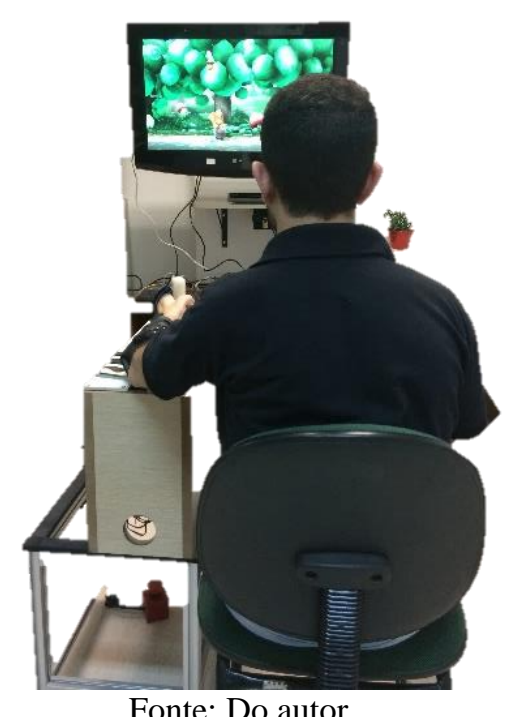

\subsection{Fase 2}

Participaram desta fase (tanto na etapa 1 quanto na etapa 2) três sujeitos com lesão do plexo braquial e dois com lesão na medula espinhal.

$\mathrm{Na}$ etapa 1, os sujeitos fizeram uso do robô MOREw para verificar a necessidade de alterações e adequação ao uso, de acordo com as especificações de cada sujeito (dificuldades e satisfação com o uso do robô) e não relataram alterações necessárias, afirmando que o robô estava de acordo com suas expectativas e pronto para o uso. Pontuaram entre bom e muito bom todos os itens do questionário, sem apresentarem queixas quanto ao funcionamento, ergonomia, funcionamento e aplicabilidade do robô. O questionário de satisfação/dificuldade pode ser acessado no Apêndice J.

Dessa forma, foi possível iniciar a etapa 2. Por se tratarem de sujeitos com alterações motoras nos membros superiores, serão mostrados em uma breve apresentação de seus perfis, 
com as características da lesão, funcionalidade e pontuação nas escalas e protocolos utilizados, tanto na avaliação inicial quanto na avaliação após três meses.

5.2.1. Perfil e avaliações dos sujeitos

Na tabela 1 verifica-se a caracterização dos sujeitos em relação aos itens: idade, sexo, tipo de lesão, tempo de lesão e tempo de tratamento.

Tabela 1 - Caracterização dos sujeitos da pesquisa Fase 2

\begin{tabular}{lccccc}
\hline & Idade & Sexo & Tipo de lesão & Data da lesão & Tempo de tratamento \\
\hline Sujeito 1 & 27 & F & LPB & Março/13 & Há mais de 12 meses \\
Sujeito 2 & 24 & M & LPB & Janeiro/2015 & Há mais de 12 meses \\
Sujeito 3 & 23 & M & LPB & Dezembro/2013 & Há mais de 12 meses \\
Sujeito 4 & 23 & M & LM & Fevereiro/2015 & Há mais de 12 meses \\
Sujeito 5 & 42 & M & LM & Outubro/2015 & Há mais de 12 meses \\
\hline
\end{tabular}

Fonte: Dados da pesquisa.

Sujeito 1 - lesão do plexo braquial: G.F.S., 27 anos, sexo feminino, destra, sofreu acidente de moto em março de 2013. Apresentou lesão completa do plexo braquial direito extraganglionar. Foi submetida em dezembro de 2013 a: exploração do plexo; micro enxerto de C5 para nervo axilar; C6 para nervo músculo-cutâneo; C7 e C8 para nervo mediano e T1 para nervo ulnar. Casada, possui 2 filhos. Realiza atividades de cuidado da casa e dos filhos.

Apresenta boa funcionalidade, com uso de mão esquerda para realização das tarefas. Como paciente previamente era destra houve a necessidade de treino para adequação e realização das atividades cotidianas com o membro esquerdo. Hoje, utiliza o membro superior direito para suporte em algumas atividades, principalmente relacionada ao bebê. Realizava sessões de terapia ocupacional semanalmente (uma vez por semana) há mais de 12 meses.

Nas avaliações utilizadas, pontuou 120 (do total de 126) na Medida de Independência Funcional (MIF), apresentando-se independente ou necessitando modificar algumas tarefas, quando apresenta dificuldades (em atividades de uso bimanual) não havendo alteração da pontuação na reavaliação após três meses.

$\mathrm{Na}$ escala funcional específica do paciente, foram avaliadas as atividades de alcance, como proposto pelo instrumento (a 10 e $45 \mathrm{~cm}$ à sua frente, em uma mesa, e a $30 \mathrm{~cm}$ da lateral do corpo testado, em uma mesa). As outras atividades de escolha foram: erguer o braço no armário acima da pia; levar copo à boca com as duas mãos. Apresentou pontuação de 2,2, sendo 
que conseguiu realizar os alcances propostos, com dificuldade, mas não conseguiu realizar as duas tarefas escolhidas. Na reavaliação, após três meses paciente apresentou melhora no padrão de alcance, realizando com menor dificuldade, porém não como realizava antes do acidente. Não conseguiu realizar as duas atividades escolhidas: erguer o braço no armário acima da pia; levar copo à boca com as duas mãos. Obteve pontuação de 2,8. Assim, verifica-se melhora na pontuação devido à melhora no alcance (Apêndice K).

Não apresentou ganho de força muscular (FM) da avaliação para a reavaliação, mantendo a mesma FM. Apresentou pequena melhora na amplitude de movimento (ADM) de abdução de ombro na reavaliação, vide tabela 2.

Sujeito 2 - lesão do plexo braquial: M. S. L. F, 24 anos, sexo masculino, destro, sofreu acidente de moto em janeiro de 2015, com lesão total do plexo braquial esquerdo, evidenciado lesão pré-ganglionar, com acometimento maior em C6. Em junho de 2016 realizou procedimento operatório de Oberlin, neurotização do nervo acessório para musculo supraespinhal.

Reside sozinho, consegue desempenhar suas atividades de vida diária e de vida prática com independência. Interrompeu os estudos após o acidente, e não está trabalhando no momento. Apresenta início de movimentação ativa de punho (flexão maior que extensão) e preensão palmar com força diminuída. Tal fato faz com que o paciente consiga utilizar a mão esquerda em algumas atividades bimanuais como apoio. Realizava sessões de terapia ocupacional semanalmente (uma vez por semana), há mais de 12 meses.

Nas avaliações utilizadas, pontuou 125 (do total de 126) na Medida de Independência Funcional (MIF), apresentando-se independente ou necessitando apenas modificação na tarefa de alimentação - faz uso de tábua adaptada para cortar alimentos. Tal pontuação manteve-se igual na reavaliação após três meses.

$\mathrm{Na}$ escala funcional específica do paciente, foram avaliadas as atividades de alcance, como proposto pelo instrumento (a 10 e $45 \mathrm{~cm}$ à sua frente, em uma mesa, e a $30 \mathrm{~cm}$ da lateral do corpo testado, em uma mesa). As outras duas atividades de escolha do paciente foram: arrumar o cabelo/acertar o boné com a mão esquerda; cortar alimentos com apoio da mão esquerda, sem o uso da tábua adaptada. Apresentou pontuação de 2,0, sendo que conseguiu realizar os alcances propostos, mas com dificuldade. Não atingiu o padrão de realização, antes do acidente, pela demora na realização do movimento e pelo esforço a ser realizado. Em relação as duas atividades escolhidas, houve pequena melhora no teste 2 (vide Apêndice K), porém não atingiu os objetivos propostos. Na reavaliação, o paciente conseguiu o desempenho quando 
modificou a forma de realizar as atividades: sentado, apoiando membro superior na mesa para o auxílio. Obteve pontuação de 3,0. Assim, verifica-se melhora na pontuação devido a melhora no alcance e na adaptação e modificação de atividades de vida diária (Apêndice K).

Em relação a goniometria e teste de força muscular (Tabela 2), apresentou pequena melhora da FM na flexão, extensão e abdução de ombro, assim como da ADM desses segmentos, melhora da FM e ADM da flexão e FM de cotovelo e de punho.

Sujeito 3 - lesão do plexo braquial: G.O.M, 23 anos, destro, sofreu acidente de moto em dezembro de 2013, com lesão alta do plexo braquial esquerdo - lesão total, luxação esternoclavicular esquerda - reduzida. Em março de 2013 realizou PO neurotização de nervo acessório para supraescapular e nervo frênico para musculo-cutâneo.

Casado, possui uma filha, trabalha no setor administrativo. Realiza atividades de vida diária, de vida prática e do trabalho com bom desempenho funcional. Realizava sessões de terapia ocupacional semanalmente (uma vez por semana), há mais de 12 meses.

Nas avaliações utilizadas, pontuou 121 (do total de 126) na Medida de Independência Funcional (MIF), apresentando-se independente para a realização de suas atividades de vida diária. Refere que esposa realiza a maior parte das atividades de vida prática, mas que consegue desempenhar, caso necessite - protocolo completo no Apêndice K. Tal pontuação manteve-se igual na reavaliação após três meses.

$\mathrm{Na}$ escala funcional específica do paciente, foram avaliadas as atividades de alcance, como proposto pelo instrumento (a 10 e $45 \mathrm{~cm}$ à sua frente, em uma mesa, e a $30 \mathrm{~cm}$ da lateral do corpo testado, em uma mesa). As outras duas atividades de escolha foram: amarrar cadarço do tênis com as duas mãos; apontar lápis com o uso bimanual. Apresentou pontuação de 2,4, sendo que conseguiu realizar os alcances propostos, com dificuldade. Não atingiu o padrão de realização, antes do acidente, pela demora na realização do movimento e pelo esforço a ser realizado. Em relação as duas atividades escolhidas, não conseguiu desempenhar (vide Apêndice K). Na reavaliação, manteve-se o padrão e pontuação das atividades, sendo que não conseguiu desempenhar as duas atividades de escolha. Manteve pontuação 2,4.

$\mathrm{Na}$ avaliação da goniometria e teste de força muscular, apresentados na Tabela 2, o sujeito 3 apresentou melhora na FM e ADM de extensão de ombro e flexão de punho.

Sujeito 4 - lesão da medula espinhal: G.R.S., 23 anos, destro, vítima de acidente automobilístico em rodovia (carro x caminhão) em fevereiro de 2015, lesão completa nível C6. 
Solteiro, reside com pais e irmã, os quais são responsáveis pelo seu cuidado. Dependente para a realização de atividades de vida diária, alimenta-se sozinho, porém é dependente para vestuário, banho, cuidados pessoais, mobilidade e transferências. Dependência total para atividades de vida prática, cuidados e gerenciamento da casa e da saúde. Não possui movimentação ativa de dedos, apresenta extensão de punho, assim, realiza preensão de objetos maiores com tenodese. Realizava sessões de terapia ocupacional semanalmente (duas vezes por semana) e de fisioterapia (duas vezes por semana).

Durante a coleta de dados, paciente necessitou passar por cirurgia para fechamento de úlcera por pressão na região sacral. Assim, não conseguiu realizar as 12 semanas de sessões preconizadas. Participou de cinco sessões. Foram realizadas avaliações iniciais e finais após estas sessões, dessa forma, como segue os critérios de inclusão, não foi excluído da amostra.

Nas avaliações utilizadas, pontuou 61 (do total de 126) na Medida de Independência Funcional (MIF), apresentando-se dependente para a realização de suas atividades de vida diária, necessitando de auxílio de terceiros em todas as atividades (mesmo a atividade de alimentação em que come sozinho, necessita que alguém prepare seu prato e supervisione) protocolo completo no Apêndice K. Tal pontuação manteve-se igual na reavaliação após as cinco sessões.

$\mathrm{Na}$ escala funcional específica do paciente, foram avaliadas as atividades de alcance, como proposto pelo instrumento (a 10 e $45 \mathrm{~cm}$ à sua frente, em uma mesa, e a $30 \mathrm{~cm}$ da lateral do corpo testado, em uma mesa). As outras duas atividades de escolha do paciente foram: auxiliar na atividade de vestuário parte inferior e auxiliar nas transferências. Apresentou pontuação de 2,8, sendo que conseguiu realizar os alcances propostos, com certa dificuldade. Não atingiu o padrão de realização, antes do acidente, pela demora na realização do movimento e pelo esforço a ser realizado. Paciente não possui habilidade de preensão, não faz movimentação ativa de dedos, apenas realiza o alcance. Em relação as duas atividades escolhidas, não conseguiu desempenhar (vide Apêndice K). Na reavaliação, manteve-se o padrão e pontuação das atividades, sendo que não conseguiu desempenhar as duas atividades de escolha. Manteve pontuação 2,8.

Nenhuma melhora evidenciada no sujeito 4, quanto a goniometria e teste de força muscular apresentados na Tabela 2 (realizou apenas 5 sessões com o uso do robô).

Sujeito 5 - lesão da medula espinhal: F.V.F., 42 anos, destro, sofreu acidente de trabalho (estrutura de $60 \mathrm{~kg}$ caiu sobre sua cabeça em outubro de 2015), sofreu trauma raquimedular C6-C7 incompleto. 
Solteiro, residia em casa fornecida pela empresa que trabalhava, dividindo a residência com outros colegas de trabalho. Após o acidente, passou a residir com irmão e mãe (que vieram de outra cidade para auxiliar nos cuidados e permanecer com paciente durante o tratamento). Apresenta-se semi-dependente para a realização de atividades de vida diária, alimenta-se sozinho, auxilia no vestuário, banho, cuidados pessoais, mobilidade e transferências. Por apresentar lesão incompleta, apresenta movimentação ativa de punho e dedos. Está retomando atividade de tocar violão. Não apresenta marcha ativa, permanece em ortostatismo apenas com auxiliares. Realizava sessões de terapia ocupacional semanalmente (duas vezes por semana) e de fisioterapia (duas vezes por semana), há mais de 12 meses.

Nas avaliações utilizadas, pontuou 73 (do total de 126) na Medida de Independência Funcional (MIF), apresentando-se semi-dependente para a realização de suas atividades de vida diária, necessitando de auxílio de terceiros ou supervisão e preparação dos mesmos. Alimentase sozinho, mas necessita que alguém prepare seu prato. Auxilia no banho, nos cuidados pessoais, nas transferências, propulsiona cadeira de rodas - protocolo completo no Apêndice K. Tal pontuação manteve-se igual na reavaliação após os três meses.

$\mathrm{Na}$ escala funcional específica do paciente, foram avaliadas as atividades de alcance, como proposto pelo instrumento (a 10 e $45 \mathrm{~cm}$ à sua frente, em uma mesa, e a $30 \mathrm{~cm}$ da lateral do corpo testado, em uma mesa). As outras duas atividades escolhidas foram: pegar objeto pequeno - moeda, cortar alimentos. Apresentou pontuação de 3,0, sendo que conseguiu realizar os alcances propostos, sem dificuldade. Em relação as duas atividades escolhidas, não conseguiu desempenhar (vide Apêndice K). Na reavaliação, manteve-se o padrão e pontuação das atividades, sendo que não conseguiu desempenhar as duas atividades de escolha. Manteve pontuação 3,0.

Em relação a goniometria e teste de força muscular, o sujeito 5 apresentou melhora na FM de flexão de ombro, ADM de supinação, FM e ADM de flexão e extensão de punho, vide Tabela 2. 
Tabela 2 - Pontuações dos sujeitos de acordo com as escalas utilizadas

\begin{tabular}{|c|c|c|c|c|}
\hline Sujeitos & $\begin{array}{c}\text { MIF } \\
\text { Antes/Depois }\end{array}$ & $\begin{array}{c}\text { Escala Funcional } \\
\text { Específica do Paciente } \\
\text { Antes/Depois }\end{array}$ & $\begin{array}{l}\text { Goniometria } \\
\text { Antes/Depois }\end{array}$ & $\begin{array}{c}\text { Força Muscular Manual } \\
\text { Antes/Depois }\end{array}$ \\
\hline $\begin{array}{l}\text { Sujeito } 1 \\
\text { (LPB) }\end{array}$ & $120 / 120$ & $2,2 / 2,8$ & $\begin{array}{c}\text { Ombro: } \\
\text { Abdução } 76^{\circ} / 80^{\circ}\end{array}$ & Sem alteração \\
\hline \multirow[t]{3}{*}{$\begin{array}{l}\text { Sujeito } 2 \\
\text { (LPB) }\end{array}$} & $125 / 125$ & $2,0 / 3,0$ & $\begin{array}{c}\text { Ombro: } \\
\text { Flexão } 18^{\circ} / 26^{\circ} \\
\text { Extensão14 } 14^{\circ} / 24^{\circ} \\
\text { Abdução } 30^{\circ} / 32^{\circ}\end{array}$ & $\begin{array}{c}\text { Ombro: } \\
\text { Flexão } 1 \text { / } 2 \\
\text { Extensão } 2 \text { / 2+ } \\
\text { Abdução } 2 \text { / 2+ }\end{array}$ \\
\hline & & & $\begin{array}{c}\text { Cotovelo: } \\
\text { Flexão } 50^{\circ} / 90^{\circ}\end{array}$ & $\begin{array}{c}\text { Cotovelo: } \\
\text { Flexão } 1 \text { / } 2 \\
\text { Extensão } 2 \text { / 2+ }\end{array}$ \\
\hline & & & $\begin{array}{c}\text { Punho: } \\
\text { Flexão } 52^{\circ} / 56^{\circ}\end{array}$ & $\begin{array}{c}\text { Punho: } \\
\text { Flexão } 4 \text { / 4+ } \\
\text { Extensão } 2 \text { / 2+ }\end{array}$ \\
\hline \multirow[t]{2}{*}{$\begin{array}{l}\text { Sujeito } 3 \\
\text { (LPB) }\end{array}$} & $121 / 121$ & $2,4 / 2,4$ & $\begin{array}{c}\text { Ombro: } \\
\text { Extensão } 0^{\circ} / 6^{\circ}\end{array}$ & $\begin{array}{c}\text { Ombro: } \\
\text { Extensão } 1 \text { / } 2\end{array}$ \\
\hline & & & $\begin{array}{c}\text { Punho: } \\
\text { Flexão } 24^{\circ} / 30^{\circ}\end{array}$ & $\begin{array}{l}\text { Punho: } \\
\text { Flexão 1/ } 2\end{array}$ \\
\hline $\begin{array}{l}\text { Sujeito } 4 \\
\text { (LM) }\end{array}$ & $61 / 61$ & $2,8 / 2,8$ & Sem alteração & Sem alteração \\
\hline \multirow[t]{2}{*}{$\begin{array}{l}\text { Sujeito } 5 \\
\text { (LM) }\end{array}$} & $73 / 73$ & $3,0 / 3,0$ & & $\begin{array}{l}\text { Ombro: } \\
\text { Flexão 4- /4+ }\end{array}$ \\
\hline & & & $\begin{array}{c}\text { Punho: } \\
\text { Flexão } 38^{\circ} / 70^{\circ} \\
\text { Extensão } 30^{\circ} / 56^{\circ} \\
\text { Supinação } 72^{\circ} / 90^{\circ}\end{array}$ & $\begin{array}{c}\text { Punho: } \\
\text { Flexão } 4 \text { / 4+ } \\
\text { Extensão } 4 \text { / } 5\end{array}$ \\
\hline
\end{tabular}

Fonte: Dados da pesquisa.

Analisando os resultados da Fase 2 de forma conjunta, podemos verificar na Tabela 2 que a pontuação da Medida de Independência Funcional (MIF) de todos os sujeitos mantiveram a mesma na reavaliação após o tempo de três meses de uso do robô. Nota-se que os pacientes se encontravam em fase crônica de tratamento, ou seja, já estavam em tratamento antes da realização do jogo e com mais de um ano de lesão, assim, já havia sido trabalhada as atividades para maximização dos ganhos funcionais (protocolo de reabilitação do serviço), e os ganhos que não foram atingidos até o momento, podem representar as sequelas evidenciadas de cada lesão, sendo mais difíceis de serem alcançadas (BENVEGNU et al., 2008; NUNES et al., 2005). 
Riberto et al. (2007) apontam para o fato de que a MIF é um instrumento útil e sensível para acompanhamento dos pacientes em reabilitação ambulatorial não-agudos no Brasil, evidenciando suas melhorias funcionais, e que os programas de reabilitação podem se mostrar eficientes na melhoria do desempenho motor e físico dos pacientes em fase crônica de tratamento, quando os ganhos são geralmente menores e pouco perceptíveis. Nota-se que os pacientes já estavam em programa de reabilitação há mais de 1 ano, ou seja, já estavam em fase crônica, assim, os ganhos funcionais máximos já haviam sido atingidos. Junto a isso, o estímulo evidenciado pelo robô tem como meta o auxílio da movimentação de punho, e as atividades de vida diária exigem outros controles motores, como uso bimanual, controle de tronco, equilíbrio, uso do membro superior como um todo (FERLA et al., 2015) os quais não foram objetivo dessa pesquisa. Portanto, para otimização e ganhos funcionais relacionados ao desempenho de atividades de vida diária, seria necessário outro enfoque de estudo, o qual não foi objetivo neste estudo.

Foi possível perceber uma diferença discrepante entre as pontuações da MIF dos sujeitos com lesão na medula espinhal dos com lesão do plexo braquial, sendo que estes últimos possuem maior desempenho funcional, e pontuaram mais na MIF (protocolo completo da MIF pode ser verificado no apêndice $\mathrm{K}$ ). Nota-se que os sujeitos com lesão do plexo braquial desempenham suas atividades bimanuais de forma adaptada, porém com independência, fazendo uso do lado sadio para a realização, e utilizam o lado parético como apoio quando necessário. Já para os sujeitos com lesão medular, como possuem ambos os lados comprometidos, tal fato não pode ser aplicado. Segundo Riberto et al. (2007), para atividades como vestuário, transferências, mobilidade e uso de escadas, há uma complexidade e variedade de habilidades exigidas para estas tarefas, como a organização da atividade motora - equilíbrio, força dos membros inferiores (MMII), amplitude articular nos MMII, destreza dos membros superiores (MMSS), que estão deficitários nos sujeitos com lesão da medula espinhal.

Ainda assim, a Medida de Independência Funcional é um instrumento amplamente utilizado e mundialmente referenciado para mensurar capacidade funcional (BENVEGNU et al., 2008), de acordo com a lesão e quanto maior o grau de acometimento motor, menor a independência funcional que o sujeito apresentará, necessitando do auxílio de terceiros para a realização das atividades de vida diária e de vida prática (RIBERTO et al., 2004).

Na Escala Funcional Específica do Paciente (Tabela 2), observamos que os sujeitos 1 e 2 obtiveram melhora no padrão de realização das atividades, diferentemente dos sujeitos 3, 4 e 5 que mantiveram a mesma pontuação. Um fato que pode ser atribuído seria que nesse tipo de instrumento, o sujeito realiza a escolha de atividades significativas em sua rotina e que gostaria 
de executá-la. Assim, a comparação se dá do sujeito com ele mesmo. Podemos observar pelo que o alcance com os membros superiores, nos diversos níveis exigidos, apresentou melhora, porém as atividades de escolhas pessoais dos sujeitos não conseguiram ser atingidas. Estas representavam atividades que exigiam grande amplitude de membros superiores, muitas vezes não condizentes com os níveis e o tipo de lesão de cada sujeito (protocolo completo da Escala Funcional Específica do Paciente pode ser verificado no apêndice K). O nível de expectativa dos pacientes que estão no processo de reabilitação física, nem sempre está em acordo com seus estados funcionais, sendo necessário que estes estejam em proximidade para diminuir frustrações ao longo da reabilitação (CARDOSO; EUSÉBIO, 2011; VIEIRA, 2013).

A escala funcional específica do paciente apresenta-se como um instrumento que fornece aos pesquisadores um conteúdo válido, confiável, responsivo através de medidas eficientes e de fácil uso de comparação (STRATFORD et al., 1995). Assim, os pacientes conseguem relatar seus estados funcionais prioritários em sua rotina ocupacional e verificar o acompanhamento destes ao longo da reabilitação, sendo um instrumento importante para mensuração e comparação de sua melhora funcional (HEFFORD et al., 2012). Para os sujeitos da pesquisa, houve melhora do alcance mensurado, sendo que dois deles tiveram melhora na pontuação. Assim, podemos inferir que a utilização do MOREw pode estar relacionada a motivação dos sujeitos para alcance de suas metas funcionais.

Ainda na tabela 2 podemos verificar os ganhos obtidos, de cada sujeito, em relação a amplitude de movimento e força muscular. Nota-se que, com exceção do sujeito 4, que não teve nenhum ganho de ADM ou FM, os outros sujeitos obtiveram melhoras na ADM e/ou FM de ombro, com melhoria de até $10^{\circ}$ na ADM e aumento de até 1 grau de FM. Em relação ao punho, o sujeito 2 obteve melhora de alguns graus de ADM, bem como melhoria da FM, mas mantendo o mesmo grau de força. Destaca-se o sujeito 5, que obteve melhora no punho de forma evidente para flexão, extensão e supinação e aumento considerável do grau de FM. Não podemos inferir que tais modificações foram devidas ao uso do robô MOREw, porém, como estes sujeitos estavam em fase crônica de tratamento, e nesta, os resultados podem ser pequenos, enfatiza-se que tais ganhos são de extrema importância para os sujeitos nessa fase de reabilitação.

Os resultados na íntegra do teste de força muscular manual e goniometria são apresentados respectivamente nas Tabelas 3 e 4 . 
Tabela 3 - Teste de força muscular manual

\begin{tabular}{lccccc}
\hline $\begin{array}{l}\text { Articulação e } \\
\text { movimento }\end{array}$ & $\begin{array}{c}\text { Sujeito 1 } \\
\text { (LPB) } \\
\text { Antes/Depois }\end{array}$ & $\begin{array}{c}\text { Sujeito 2 } \\
\text { (LPB) }\end{array}$ & $\begin{array}{c}\text { Sujeito 3 } \\
\text { (LPB) }\end{array}$ & $\begin{array}{c}\text { Sujeito 4 } \\
\text { (LM) }\end{array}$ & $\begin{array}{c}\text { Sujeito 5 } \\
\text { (LM) }\end{array}$ \\
\hline $\begin{array}{l}\text { Ombro } \\
\text { Flexão }\end{array}$ & $3+/ 3+$ & $2 / 2+$ & $4-/ 4-$ & $4 / 4$ & $4-/ 4+$ \\
Extensão & $2-/ 2-$ & $1 / 2$ & $1 / 2$ & $5 / 5$ & $5 / 5$ \\
Abdução & $4 / 4$ & $2 / 2+$ & $4-/ 4-$ & $4 / 4$ & $5 / 5$ \\
Cotovelo & & & & & \\
$\quad$ Flexão & $3 / 3$ & $1 / 2$ & $4+/ 4+$ & $5 / 5$ & $5 / 5$ \\
$\quad$ Extensão & $3 / 3$ & $2 / 2+$ & $4 / 4$ & $3 / 3$ & $5 / 5$ \\
Punho & & & & & \\
$\quad$ Flexão & $2 / 2$ & $4 / 4+$ & $1 / 2+$ & $2 / 2$ & $4 / 4+$ \\
$\quad$ Extensão & $2 / 2$ & $2 / 2+$ & $1 / 1$ & $5 / 5$ & $4 / 5$ \\
$\quad$ Pronação & $2 / 2$ & $2 / 2$ & $2 / 2$ & $3 / 3$ & $3 / 3$ \\
Supinação & $2 / 2$ & $1 / 1$ & $3 / 3$ & $5 / 5$ & $3 / 3$ \\
Preensão palmar kg & $0 / 0$ & $1 / 1$ & $0 / 0$ & $0 / 0$ & $2,5 / 2,5$ \\
\hline
\end{tabular}

Fonte: Dados da pesquisa.

Tabela 4 - Goniometria

$\begin{array}{lccccc}\begin{array}{l}\text { Articulação e } \\ \text { movimento }\end{array} & \begin{array}{c}\text { Sujeito 1 } \\ \text { (LPB) }\end{array} & \begin{array}{c}\text { Sujeito 2 } \\ \text { (LPB) }\end{array} & \begin{array}{c}\text { Sujeito 3 } \\ \text { (LPB) }\end{array} & \begin{array}{c}\text { Sujeito 4 } \\ \text { (LM) }\end{array} & \begin{array}{c}\text { Sujeito 5 } \\ \text { (LM) }\end{array}\end{array}$

Antes/Depois Antes/Depois Antes/Depois Antes/Depois Antes/Depois

\section{Ombro}

Flexão

Extensão

$74^{\circ} / 74^{\circ}$

$18^{\circ} / 26^{\circ}$

$70^{\circ} / 70^{\circ}$

$126^{\circ} / 126^{\circ}$

$180^{\circ} / 180^{\circ}$

Abdução

$6^{\circ} / 6^{\circ}$

$14^{\circ} / 24^{\circ}$

$0^{\circ} / 6^{\circ}$

$40^{\circ} / 40^{\circ}$

$36^{\circ} / 36^{\circ}$

Cotovelo

Flexão

$76^{\circ} / 80^{\circ}$

$30^{\circ} / 32^{\circ}$

$56^{\circ} / 56^{\circ}$

$134^{\circ} / 134^{\circ}$

$180^{\circ} / 180^{\circ}$

Extensão

$70^{\circ} / 70^{\circ}$

$50^{\circ} / 90^{\circ}$

$106^{\circ} / 106^{\circ}$

$130^{\circ} / 130^{\circ}$

$144^{\circ} / 144^{\circ}$

Punho

\begin{tabular}{lccccc} 
Flexão & $16^{\circ} / 16^{\circ}$ & $52^{\circ} / 56^{\circ}$ & $24^{\circ} / 30^{\circ}$ & $32^{\circ} / 32^{\circ}$ & $38^{\circ} / 70^{\circ}$ \\
Extensão & $2^{\circ} / 2^{\circ}$ & $10^{\circ} / 10^{\circ}$ & $0^{\circ} / 0^{\circ}$ & $60^{\circ} / 60^{\circ}$ & $30^{\circ} / 56^{\circ}$ \\
Pronação & $46^{\circ} / 46^{\circ}$ & $90^{\circ} / 90^{\circ}$ & $90^{\circ} / 90^{\circ}$ & $90^{\circ} / 90^{\circ}$ & $90^{\circ} / 90^{\circ}$ \\
Supinação & $40^{\circ} / 40^{\circ}$ & $0^{\circ} / 0^{\circ}$ & $30^{\circ} / 30^{\circ}$ & $90^{\circ} / 90^{\circ}$ & $72^{\circ} / 90^{\circ}$ \\
\hline
\end{tabular}


Verificado que $80 \%$ dos sujeitos da amostra apresentaram algum tipo de melhora em relação a força muscular ou amplitude de movimento de algum segmento corporal, sendo que um sujeito, não apresentou nenhum ganho. Vale ressaltar que o sujeito 4 não foi excluído da amostra, pois, apesar de ter realizado apenas cinco semanas do jogo, enquadrava-se nos critérios de inclusão, realizou as avaliações iniciais e finais, sendo que sua experiência de uso e apropriação do robô foi importante para enriquecimento do estudo.

A movimentação exigida pelo robô é prioritariamente a mobilização ativo-assistida de flexão e extensão de punho, porém pode ser observado que durante a realização das sessões dos jogos, os sujeitos compensavam o movimento de punho (que apresentam diminuição de FM ou ADM) com a realização da movimentação de cotovelo e ombro para assim atingir o alvo com mais facilidade. Dessa forma, o membro superior como um todo estava ativo no jogo.

Outro fato a ser apontado seria que alguns sujeitos apresentaram pequenas melhoras em ADM, porém não necessariamente melhoras na FM desse segmento ou então, pequena melhora na FM e não apresentou melhora na ADM do mesmo segmento corporal. Tal questão pode ser atribuída ao fato de que as melhoras evidenciadas se aplicam a pequenos ganhos. Assim, a melhora de alguns graus na ADM de ombro, por exemplo, não justifica a melhora na FM desse segmento a fim de modificação no grau de FM apresentado. O contrário também foi observado, em que alguns sujeitos apresentaram ganho de FM (modificação de 1 grau), porém não apresentaram modificações na ADM.

Não se pode afirmar que os ganhos obtidos na força muscular e amplitude de movimento, apresentados nas Tabelas 2, 3 e 4, são designados pelo uso com o robô, por limitações do próprio estudo, relacionados ao pequeno número de sujeitos e falta de avaliação da evolução do processo terapêutico antes desta intervenção. Mas a opinião dos sujeitos mostra que esse recurso foi de extrema importância para eles, principalmente relacionado à motivação frente ao desafio do jogo, em fazer uso de nova estratégia no tratamento que associado à reabilitação convencional apresentou melhora.

A literatura aponta benefícios do uso de jogos na reabilitação visando a melhora na motivação e nos ganhos funcionais de pacientes que sofreram AVE, tanto na fase aguda quanto na crônica (BURDEA, 2003; SAPOSNIK; MINDY; STROKE OUTCOME RESEARCH CANADA (SORCan) WORKING GROUP, 2011).

Além disso, diversas pesquisas apontam para o fato de que o uso de jogos associados a dispositivos robóticos podem contribuir para aumentar a recuperação motora em sujeitos com AVE, amplificando os ganhos associados a reabilitação convencional (BOVOLENTA et al., 
2009; KREBS et al., 2003; KWAKKEL; KOLLEN; KREBS, 2008; MEHRHOLZ et al., 2008; NOROUZI-GHEIDARI; ARCHAMBAULT; FUNG, 2012; SALE et al., 2014; ZIHERL et al., 2010). Nestes, há evidências da melhora motora dos membros superiores acometidos pelo AVE, porém pouca melhora funcional nas atividades de vida diária evidenciadas, assim como os resultados apontados nesse estudo. Ainda assim, é possível verificar que os estudos abordados na literatura são realizados com pessoas que sofreram AVE, sendo necessário a realização de estudos que abordem sujeitos com outras lesões que acometem o sistema nervoso central e periférico, assim como apresentamos nessa pesquisa.

Em relação aos dados do protocolo Think aloud e do Questionário de satisfação/dificuldade com o robô MOREw, a amostra apresentou satisfação na realização das sessões com o robô, na melhora do desempenho e da união dessa estratégia com as terapias já realizadas semanalmente. Santos (2016) aponta para o fato de que jogos na reabilitação auxiliam na motivação do paciente frente ao processo de terapia, visto que este é longo e contínuo, e o fator motivacional é crucial tanto para a efetividade do tratamento quanto para a velocidade de sua recuperação.

Os dados desses protocolos podem ser observados nas Tabelas 5 e 6 , que se referem a aplicabilidade e o funcionamento do robô, após o uso por três meses. As respostas foram agrupadas de acordo com suas categorias e porcentagem de aparecimento. Também podemos verificar as necessidades futuras de modificações para sanar as problemáticas ainda apresentadas.

Tabela 5 - Protocolo Think aloud avaliação final após três meses

\begin{tabular}{lcl}
\hline Frases Categorizadas & $\begin{array}{c}\text { \% de } \\
\text { aparecimento } \\
\text { (sujeitos) }\end{array}$ & Necessidades futuras \\
\hline $\begin{array}{l}\text { Braçadeira desconfortável ao longo do } \\
\text { tempo (necessário maior regulagem de } \\
\text { altura, maior proximidade do corpo) }\end{array}$ & $100 \%$ & $\begin{array}{l}\text { - Melhorar design da mesa } \\
\text { com regulagem de altura } \\
\text { - Regulagem da braçadeira de } \\
\text { acordo com a estatura do } \\
\text { sujeito } \\
\text { - Mais próxima ao corpo e } \\
\text { ajustável a cada sujeito }\end{array}$ \\
$\begin{array}{l}\text { Muito interessante, adorei e gostaria de } \\
\text { continuar utilizando }\end{array}$ & $80 \%$ & $\begin{array}{l}\text { - Alteração da música ou } \\
\text { diminuição do volume em } \\
\text { alguns casos }\end{array}$ \\
$\begin{array}{l}\text { Alça para fixação da manopla necessita } \\
\text { de ajustes, fixar de melhor forma }\end{array}$ & $20 \%$ & $\begin{array}{l}\text { - Melhorar alça para fixação } \\
\text { da mão na manopla }\end{array}$ \\
\hline
\end{tabular}

Fonte: Dados da pesquisa. 
Tabela 6 - Questionário satisfação/dificuldade* com o uso do robô MOREw avaliação final após três meses

\section{Queixas mencionadas}

Fixação do braço na manopla

Conforto do equipamento

Movimentação da manopla

(fixação da mão na manopla)

Ajustes no jogo

(ter a possibilidade de ser mais fácil ou mais difícil, terapeuta fazer a regulagem, com ou sem cooperação em ajustes no esforço para atingir o alvo)

Ter outras fases do jogo, modificar música

$$
\% \text { de }
$$

aparecimento Necessidades futuras (sujeitos)

$\begin{array}{ll}100 \% & \text { - Mais próximo ao corpo } \\ 40 \% & \begin{array}{l}\text { - Maior proximidade do } \\ \text { corpo, menor tamanho da } \\ \text { caixa robótica }\end{array} \\ & - \text { Maior conforto e melhor } \\ & \text { fixação com a alça } \\ & - \text { Modificações no grau de } \\ & \text { dificuldade. O Terapeuta } \\ & \text { poderá fazer essas } \\ & \text { modificações conforme a } \\ & \text { necessidade do sujeito } \\ & - \text { Ampliação do jogo }\end{array}$

*Os questionários dos sujeitos podem ser verificados na íntegra no apêndice J.

Fonte: Dados da pesquisa

A primeira necessidade de modificação percebida pelos sujeitos foi em relação ao auxiliar de preensão - luva, que foi desenvolvida na fase 1. Esta, já apresentada anteriormente na Figura 9, auxiliava na fixação da mão na manopla, porém restringia a movimentação do punho, principalmente para os sujeitos com pouca ADM de punho - movimentos de flexão e extensão. Assim, foi confeccionado uma alça (Figura 14), que possibilitasse a fixação da mão na manopla, mas que não restringisse a movimentação do movimento, acarretando maior liberdade de movimento e menor resistência.

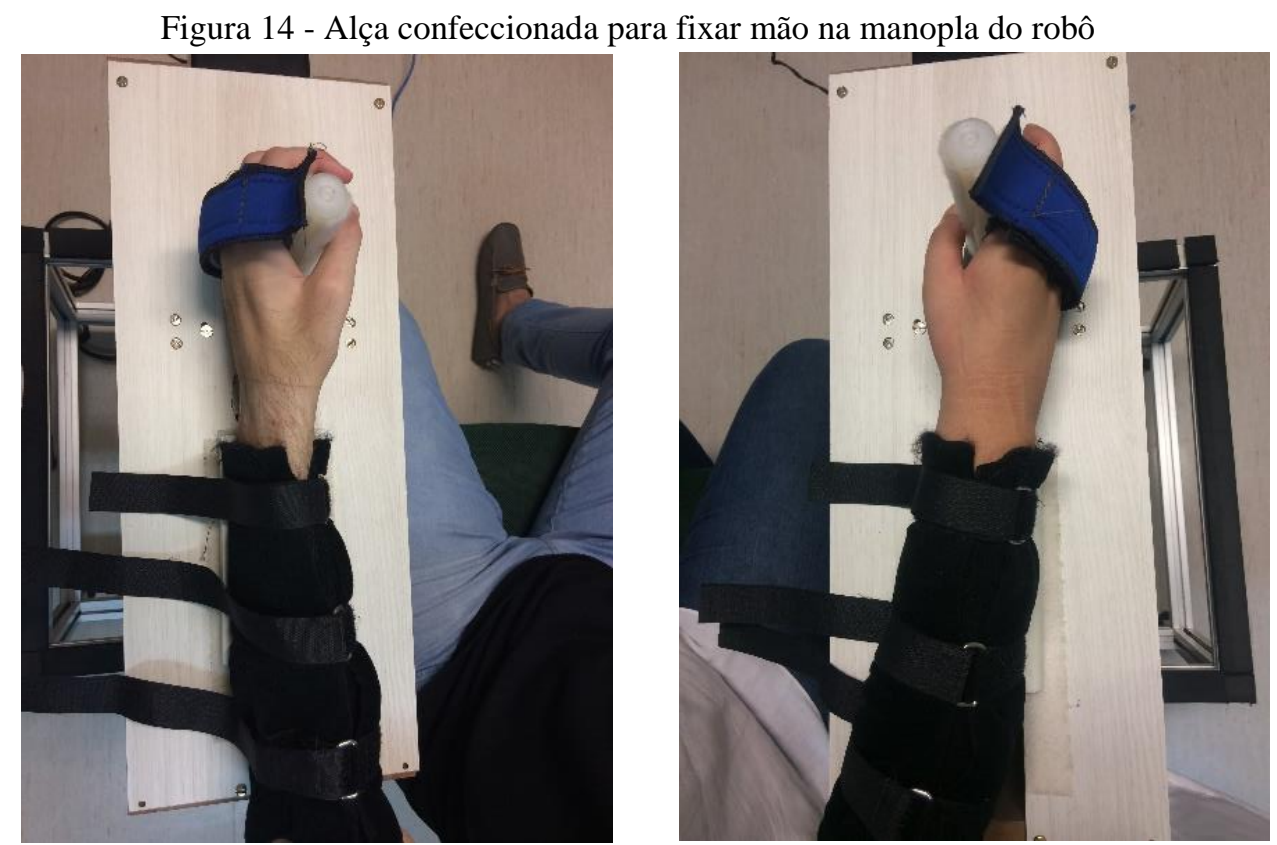

Fonte: Dados da pesquisa. 
Os sujeitos referiram satisfação no uso da alça, porém apontam, como sugestão, que esta deve ser aperfeiçoada para melhorar a fixação na manopla com maior segurança no movimento (melhora no design).

Através da Tabela 5 é possível verificar que ao longo dos três meses de uso com o robô, $100 \%$ referiram insatisfação com o posicionamento do braço na braçadeira, tanto pela regulagem de altura, quanto pela dificuldade de aproximação ao longo do corpo. Nota-se que, pelo fato da braçadeira ser fixa na caixa que acomoda o sistema robótico, a aproximação desta com o corpo do sujeito permanece deficitária. Tal fato pode ser acentuado quando o sujeito faz uso de cadeira de rodas, como é demonstrado na Figura 15.

Figura 15 - Dificuldade na aproximação do corpo ao robô MOREw
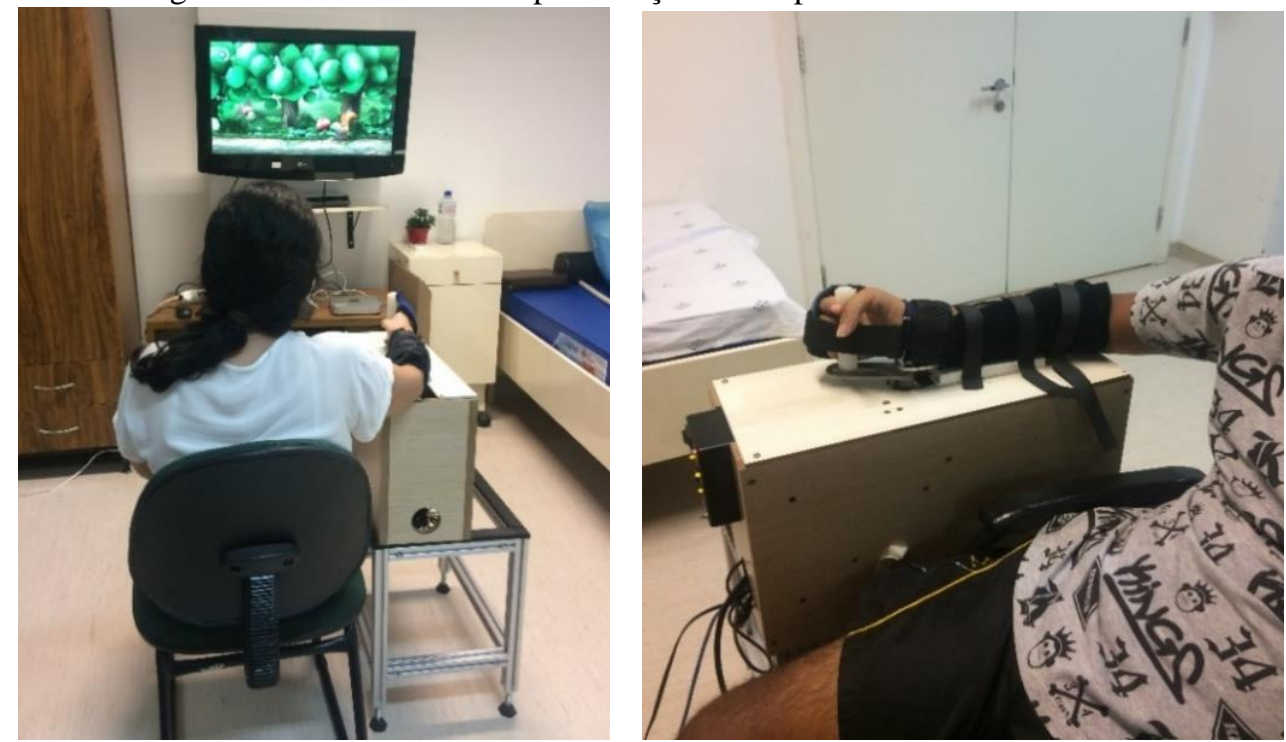

Fonte: Dados da pesquisa.

Figura 16 - Dificuldade na regulagem da altura do robô MOREw junto ao corpo

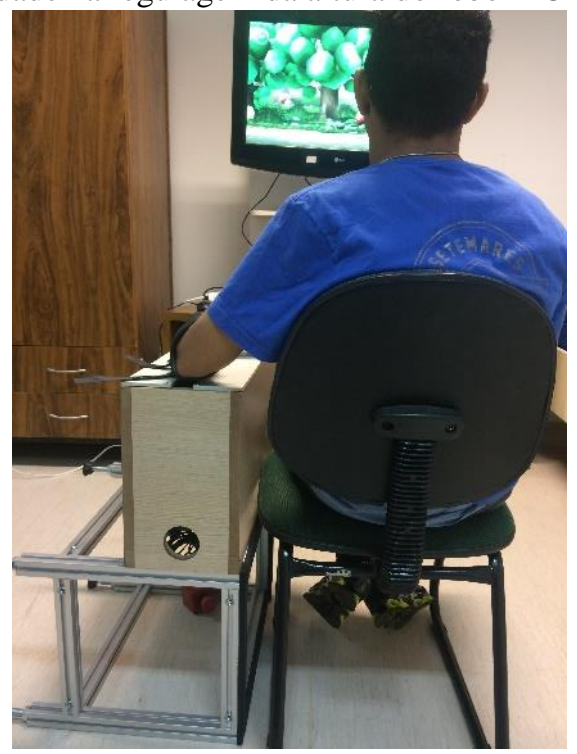

Legenda: Mesmo com a regulagem de altura, ainda permanece alta para pessoas com estatura baixa Fonte: Dados da pesquisa. 
Também na Figura 16 verificamos que mesmo a mesa possuindo regulagem de altura, ainda não foi suficiente para adequação em sujeitos com baixa estatura. Santos (2016), aponta para o fato de que o jogo, utilizado na reabilitação, deve ser adaptável a cada sujeito de acordo com sua necessidade, mesmo para sujeitos que possuem o mesmo tipo de lesão.

Verifica-se que uma pequena porcentagem da amostra (20\%, que representa 1 sujeito da amostra) refere insatisfação com a música, fato que pode ser atenuado pela diminuição do volume do som.

Diversas foram as frases, de $100 \%$ dos sujeitos referentes a satisfação em uso do robô MOREw, tanto como estimulante, motivador ao processo de tratamento, como um excelente mecanismo para estímulo da movimentação de flexo-extensão do punho, visto que a motivação frente ao jogo, possibilita o maior número de repetições. Tal fato apresenta-se como fator crucial para a reabilitação, e faz com que o uso de estratégias motivadores facilitem tal processo para a maximização dos ganhos (KWAKKEL; KOLLEN; KREBS, 2008; MAZZOLENI et al., 2013; MEHRHOLZ et al., 2008; POSTERARO et al., 2010; PRANGE et al., 2006).

Em relação às respostas do Questionário de satisfação/dificuldade com o uso do robô MOREw (Tabela 6), foi possível verificar que diferentemente da avaliação inicial, que os sujeitos pontuaram as alternativas com respostas que variavam de bom a muito bom para quase todas as categorias, na reavaliação após três meses, apresentaram piora na pontuação do instrumento apresentando necessidades de modificações. Estas corroboram com as respostas apresentadas no protocolo Think aloud, em relação a necessidade de melhoria da fixação do braço na manopla, maior conforto do equipamento e necessidade de ajustes no jogo.

A possibilidade de ajustes, por parte do terapeuta, é de extrema importância no contexto de reabilitação, pois permite que variáveis estejam de acordo com os objetivos da terapia. Assim, o terapeuta pode adequar a graduação do nível de dificuldade, alteração da velocidade e da distância espacial de queda da noz, tornando o jogo adaptado às necessidades de cada sujeito.

O item "indicação para outra pessoa" apresentou como resposta 100\% de satisfação dos sujeitos. Estes reforçam a importância de uso de novas tecnologias na reabilitação, associados as terapias convencionais, pois aumentam a motivação e dinamizam o tratamento.

Pode-se perceber que, mesmo após as modificações e ajustes necessários, o robô ainda necessita de melhorias ergonômicas, estruturais e de ajustes no jogo. Porém, ainda assim mostrou-se eficiente, motivador, sendo reconhecido pelos sujeitos que fizeram uso, como um ótimo instrumento a ser utilizado na reabilitação. 


\subsubsection{Desempenho dos sujeitos nas sessões do jogo}

Durante a realização de cada sessão, os dados foram salvos em um banco de dados desenvolvido pelos programadores. Assim, o tempo de realização e número de acertos (desempenho do sujeito em casa sessão) puderam ser avaliados.

Desde o início dos testes, a pesquisadora principal e os sujeitos do estudo estavam em acordo quanto a percepção de modificações e necessidades para viabilizar o uso (as quais já foram apresentadas anteriormente), e, com a necessidade da confecção da alça para estabilização da mão do sujeito na manopla, pode-se perceber que, alguns recursos do jogo facilitavam o acerto do alvo e a melhor pontuação e outros exigiam maior esforço do punho, ou seja, acarretava maior dificuldade durante a sessão.

Com os recursos que facilitavam a realização do jogo que levam à maior pontuação e melhor desempenho do sujeito podemos citar: a cooperação existente no jogo (que auxiliava o jogador a alcançar o alvo nas situações mais difíceis e de maior exigência), a luva para estabilização da mão na manopla (proporcionava maior fixação e segurança no jogo) e por último, a calibração livre no início do jogo, ou seja, quando o robô mensurava o máximo de flexão e extensão que o sujeito conseguia realizar de forma ativa, ou seja, sem a influência do terapeuta. Assim, foi percebido que essas situações favoreciam o desempenho do sujeito durante as sessões, fazendo com que a pontuação, ao final do jogo, fosse mais satisfatória.

Porém, foram realizados outros testes, com outras variáveis, para que houvesse comparação com o desempenho realizado, por exemplo, o uso da alça para estabilização da mão na manopla, em detrimento da luva, se mostrou mais efetiva propiciando maior liberdade do movimento do punho para a realização da tarefa, ou seja, exigia-se mais do sujeito quanto a realização ativa de flexo-extensão do punho.

Outro fato que também contribuiu para que os sujeitos realizassem maior esforço durante os movimentos do punho foi quando a cooperação não foi acionada (nota-se que o jogo estava programado para sempre ter a cooperação ativada, porém, em algumas situações, houve falha da cooperação, assim pode-se avaliar o desempenho dos sujeitos no jogo sem a cooperação ativada). Como era esperado, o não auxílio da cooperação também exigiu maior desempenho por parte dos sujeitos, entretanto havendo piora na pontuação total.

Algumas sessões também foram realizadas com auxílio ativo-assistido do terapeuta durante a calibração do jogo: nas primeiras jogadas, quando o sujeito deveria executar o máximo de movimentação ativa de flexo-extensão de punho, o terapeuta ampliava 10 graus a mais do que o sujeito conseguisse realizar, a fim de que a calibração que ficasse salva no jogo 
apresentasse uma maior amplitude de movimento do que o sujeito possuía. Com isso, o grau de dificuldade que o jogo apresentaria seria maior. Como também era esperado, com o maior grau de dificuldade, maior foi a exigência do jogo para a realização dos movimentos de flexoextensão de punho e também menor a pontuação no final da sessão.

Apesar de algumas sessões serem realizadas com estas dificuldades impostas, os jogadores relataram no protocolo Think aloud, (100\%) que as sessões que haviam sido realizadas com tais dificuldades, foram as que eles perceberam maior empenho e maior uso da musculatura do membro superior para a realização da movimentação de punho. Assim, apesar da pontuação ter sido inferior ao final destas sessões, os sujeitos referiram que sentiram que realizavam o jogo com maior empenho e motivação para alcançarem o alvo.

Portanto, é possível perceber que os melhores desempenhos dos sujeitos se deram com o uso da luva, cooperação acionada e calibração livre, pois facilitaram a realização dos movimentos, mesmo quando o sujeito possuía grande dificuldade para execução da amplitude de movimento de flexão e extensão de punho e viabilizou a realização do jogo, motivando o participante para a execução, levando a uma maior pontuação ao final.

Já nas sessões que ocorreram com as dificuldades impostas: alça para fixação da mão, sem auxílio de cooperação e aumento da amplitude de movimento de flexo-extensão de punho durante a calibração, também demonstraram ser importantes no processo de reabilitação, pois agiram como motivador à medida que dificultaram a realização do jogo e assim criou-se novos desafios na reabilitação.

Percebe-se que ambas as situações são importantes para o processo de reabilitação e cabe ao terapeuta avaliar e analisar quais as variáveis necessárias para o desempenho do sujeito em cada sessão. Desta forma, acredita-se ser de extrema importância que os parâmetros mencionados acima possam ser programados pelo terapeuta durante as terapias, de acordo com o objetivo traçado para a sessão, o desempenho do sujeito e seu progresso na terapia. 


\section{CONCLUSÃO}

Os objetivos foram alcançados e deve-se ao aprimoramento e melhorias concretizadas no robô MOREw para que seu funcionamento e aplicabilidade estivessem de acordo com as necessidades do processo de reabilitação. Assim, o MOREw mostrou-se efetivo como auxiliar terapêutico para o tratamento de sujeitos que sofreram lesões do plexo braquial e lesão da medula espinhal. As modificações concretizadas ao longo do estudo foram de extrema importância para sua adequação a essa população.

As adequações feitas na fase 1 apresentaram-se como fundamentais para que o desempenho mecânico, a interface jogo-robô e acessórios pudessem ser concretizadas para a realização dos testes na fase 2 .

Em relação ao desempenho mecânico e interface jogo-robô, apresentou-se adequado, com facilidade no uso e acessível aos sujeitos da amostra. Os acessórios utilizados mostraram-se úteis e essenciais para o uso do robô.

Mesmo sendo um único movimento permitido (flexão e extensão de punho), houve indícios de que o uso do robô possibilitou a melhora de outras musculaturas (de ombro e cotovelo, verificadas no ganho de FM e ADM dos sujeitos). Também verificamos que houve ganhos funcionais, apresentados na melhoria do alcance de objetos.

Nota-se a importância do uso de estratégias inovadoras e motivadoras, como o uso de jogos com auxílios robóticos, para motivação e empenho dos sujeitos no processo de reabilitação, como foi apresentado nesse estudo e que corroboram com estudos internacionais evidenciados.

Apresentou-se adequado ao uso com sujeitos com lesão do plexo braquial e lesão da medula espinhal, sendo um importante recurso a ser utilizado no processo de reabilitação, associado ao tratamento convencional.

A continuidade de estudos futuros tem sua importância para verificar as questões identificadas pelos sujeitos da amostra, em relação a melhoria da alça de posicionamento da mão na manopla, melhor posicionamento do braço no equipamento robótico, e modernização do design robótico. Em relação a interface jogo-robô necessita de melhorias para adequação das sessões aos propósitos do tratamento para permitir que o terapeuta tenha maior controle dos ajustes de funcionamento (controle das variáveis) e assim consiga modificar as sessões com o robô de acordo com os objetivos terapêuticos.

Faz-se necessário ainda, abordar a comparação de grupos, em estudos longitudinais para verificar a eficácia nos componentes motores durante o processo de reabilitação com uso de jogos robóticos. 


\section{REFERÊNCIAS}

ANDRADE, K.O. et al. Dynamic difficulty adjustment with evolutionary algorithm in games for rehabilitation robotics. In: INTERNATIONAL CONFERENCE ON SERIOUS GAMES AND APPLICATIONS FOR HEALTH, 4., 2016, Orlando. Proceedings... Red Hook: Institute of Electrical and Electronics Engineers, 2016. p. 1-8.

ANDRADE, K.O. et al. Dynamic player modelling in serious games applied to rehabilitation robotics. In: SBR LARS ROBOCONTROL, 2014, São Carlos. Proceedings... Piscataway: The Institute of Electrical and Electronics Engineers, 2014. p. 211-216. doi.org/10.1109/SBR.LARS.Robocontrol.2014.41.

ASIMOW, M. Introduction to design. Prentice Hall, 1968.

BACK, N.; FORCEllini, F.A. Projeto de Produtos. Apostila (Disciplina de Projeto Conceitual e Projeto para Manufatura do Programa de Pós-Graduação em Engenharia Mecânica). Universidade Federal de Santa Catarina, Florianópolis, 2003.

BALBI, L.L. et al. Tradução com adaptação cultural para a língua portuguesa do questionário Patient Specific Functional Scale (PSFS) e análise da sua confiabilidade. CONGRESSO BRASILEIRO DE REABILITAÇÃO DE MÃO, 14., 2017, Rio de Janeiro. Anais... Rio de Janeiro: Revista Interinstitucional Brasileira de Terapia Ocupacional, 2017. p. 7-8.

BARRECA, S. et al. Treatment interventions for the paretic upper limb of stroke survivors: a critical review. Neurorehabilitation \& Neural Repair, Thousand Oaks, v. 17, n. 4, p. 220226, dez. 2003.

BATISTA, K.T.; ARAUJO, H.J. Reabilitação na paralisia parcial do plexo braquial. Revista Brasileira de Cirurgia Plástica, São Paulo, v. 28, n. 1, p. 175-179, jan./mar. 2013.

BATISTA, K.T; ALMEIDA, C.E.F. Epidemiologia das lesões traumáticas tardias de nervo periférico do membro superior. Revista Brasileira de Cirurgia Plástica, São Paulo, v. 23, n. 1, p. 26-30, jan./mar. 2008.

BATISTA, L.H. et al. Avaliação da amplitude articular do joelho: correlação entre as medidas realizadas com o goniômetro universal e no dinamômetro isocinético. Revista Brasileira de Fisioterapia, São Carlos, v. 10, n. 2, p. 193-198, 2006.

BAXTER, M. Projeto de produto: guia prático para o design de novos produtos. 2. ed. São Paulo: Edgard Blücher, 2003.

BENVEGNU, A.B. et al. Avaliação da Medida de Independência Funcional de indivíduos com sequela de Acidente Vascular Encefálico (AVE). Ciência \& Saúde Coletiva, Rio de Janeiro, v. 1, n. 2, p. 71-77, jul./dez. 2008.

BOVOLENTA F. et al. Robot therapy for functional recovery of the upper limbs: a pilot study on patients after stroke. Journal of Rehabilitation Medicine, Upssala, v. 41, n. 12, p. 971-975, nov. 2009. 
BRASIL. Ministério da Saúde (MS). Secretaria de Atenção à Saúde. Departamento de Ações Programáticas Estratégicas. Diretrizes de atenção à pessoa com lesão medular. Brasília: Ministério da Saúde, 2013.

BURDEA, G.C. Virtual rehabilitation-benefits and challenges. Methods of Information in Medicine, Stuttgart, v. 42, n. 5, p. 519-23, fev. 2003.

CARDOSO, R.; EUSÉBIO, A. Actividades da vida diária: abordagens e práxis como contributo para a melhoria da qualidade de vida na pessoa com deficiência. Revista Cidade Solidária, Lisboa, v. 25, p. 30-35, 2011.

CERVANTES, B.M.N.; FUJITA, M.S.L.; NARDI, M.I.A. Pesquisa terminológica para a elaboração de linguagem documentária. In: ENCONTRO NACIONAL DE PESQUISA EM CIÊNCIA DA INFORMAÇÃO, 5., 2003, Belo Horizonte. Anais... Belo Horizonte: UFMG, 2003.

COHEN, A.D. Using, verbal reports in research on language learning. In: KASPER, G.; FAERCH, K. (Eds.) Introspection in second language research. Clevedon: Multilingual Matters, 1987.

COURA, A.S.; FRANÇA, I.S.X. de; ENDERS, B.C.; BARBOSA, M.L.; SOUZA, J.R.S. Incapacidade funcional e associações com aspectos sociodemográficos em adultos com lesão medular. Revista Latino-Americana de Enfermagem, Ribeirão Preto, v. 20, n. 1, fev. 2012.

CSIKSZENTMIHALYI, M. Flow: the psychology of optimal experience. New York: Harper \& Row, 1990.

CUPERSCHMID, A.R.M.; HILDEBRAND H.R. Heurísticas de jogabilidade: usabilidade e entretenimento em jogos digital. São Paulo: Marketing Aumentado, 2013.

DUBUISSON, A.S.; KLINE, D.G. Brachial plexus injury: a survey of 100 consecutive cases from a single service. Neurosurgery, Baltimore, v. 51, n. 3, p. 673-683, set. 2002.

FERLA, F.L.; GRAVE, M.; PERICO, E. Fisioterapia no tratamento do controle de tronco e equilíbrio de pacientes pós AVC. Revista Neurociências, São Paulo, v. 23, n. 2, p. 211-217, 2015.

FONTELLES, M.J. et al. Metodologia da pesquisa científica: diretrizes para a elaboração de um protocolo de pesquisa. Revista Paraense de Medicina, Belém, v. 23, n. 3, p. 1-8, jul./set. 2009.

FRANCESCHINI, M. et al. Clinical relevance of action observation in upper-limb stroke rehabilitation: a possible role in recovery of functional dexterity. A randomized clinical trial. Neurorehabilitation \& Neural Repair, Thousand Oaks, v. 26, n. 5, p. 456-462, jun. 2012.

HEFFORD, C. et al. The Patient-Specific Functional Scale: validity, reliability, and responsiveness in patients with upper extremity musculoskeletal problems. Journal of Orthopaedic and Sports Physical Therapy, Alexandria, v. 42, n. 2, p. 56-65, fev. 2012. 
KAMINSKI, P. C. Desenvolvendo produtos com planejamento, criatividade e qualidade. Rio de Janeiro: LTC, 2000.

KANG, L.; WOLFE, S. Traumatic brachial plexus injuries. In: SKIRVEN, T. et al. (Eds.). Rehabilitation of the hand and upper extremity. 6 ed. Philadelphia: Elsevier, 2011. p. 749759.

KIRSHBLUM, S.C. et al. International standards for neurological classification of spinal cord injury (revised 2011). The Journal of Spinal Cord Medicine, Londres, v. 34, n. 6, p. 535-546, nov. 2011.

KREBS, H.I. et al. Increasing productivity and quality of care: robot-aided neuro-rehabilitation, Journal of Rehabilitation Research and Development, Baltimore, v. 37, n 6, nov./dez. 2000.

KREBS, H.I. et al. Rehabilitation robotics: Performance based progressive robot-assisted therapy. Autonomous Robots, Dordrecht, v. 15, n. 1, p. 7-20, jul. 2003.

KREBS, H.I. et al. Robot aided neurorehabilitation. IEEE Transactions on Rehabilitation Engineering, New York, v. 6, n. 1, p. 75-87, mar. 1998.

KREBS, H.I. et al. Robot-aided neurorehabilitation: A robot for wrist rehabilitation. IEEE Transactions on Neural Systems and Rehabilitation Engineering, New York, v. 15, n. 3, p. 327-335, set. 2007.

KWAKKEL, G. et al. Intensity of leg and arm training after primary middle-cerebral artery stroke: a randomized trial. Lancet, Londres, v. 354, n. 9174, p. 191-196, jul. 1999.

KWAKKEL, G.; KOLLEN, B.J.; KREBS, H.I. Effects of robot-assisted therapy on upper limb recovery after stroke: a systematic review. Neurorehabilitation \& Neural Repair, Thousand Oaks, v. 22, n. 2, p. 111-121, mar./abr. 2008.

LEE, B. et al. The global map for traumatic spinal cord injury epidemiology: update 2011, global incidence rate. Spinal Cord, Londres, v. 52, n. 2, p. 110-116, fev. 2013.

LUM, P.S. et al. Robot-assisted movement training compared with conventional therapy techniques for the rehabilitation of upper-limb motor function after stroke. Archives of Physical Medicine and Rehabilitation, Philadelphia, v. 83, n. 7, p. 952-959, jul. 2002.

MASIERO, S. et al. Robotic-assisted rehabilitation of the upper limb after acute stroke. Archives of Physical Medicine and Rehabilitation, Philadelphia, v. 88, n. 2, p. 142-149, fev. 2007.

MATHIOVETZ, V. et al. Grip and pinch strength: normative data for adults. Archives of Physical Medicine and Rehabilitation, Philadelphia, v. 66, n. 2, p. 69-74, fev. 1985.

MAYNARD, F.M. et al. International standards for neurological and functional classification of spinal cord injury. Spinal Cord, Londres, v. 35, n. 5, p/ 266-274, maio 1997.

MAZZOLENI, S. et al. Upper limb robot-assisted therapy in chronic and subacute stroke patients: a kinematic analysis. American Journal of Physical Medicine \& Rehabilitation, Baltimore, v. 92, n. 10 (supl. 2), p. 26-37, out. 2013. 
MEHRHOLZ, J. et al. Electromechanical and robot-assisted arm training for improving arm function and activities of daily living after stroke. The Cochrane Database of Systematic Reviews, v. 8, n. 4, out. 2008.

MILLER, D.W.; HAHN, F.F. General methods of clinical examination. In: Winn, H.R. (Ed). Youmans Neurological Surgery, 4th ed. Philadelphia: WB Saunders Company, 1996. p. 3132.

MOREIRA, D. et al. Abordagem sobre preensão palmar utilizando o dinamômetro JAMAR®: uma revisão de literatura. Revista Brasileira de Ciência e Movimento, Brasília v. 11 n. 2 p. 95-99, jun. 2003.

NAPIER, J. The prehensile movements of human hand. The Bone \& Joint Journal, Londres, v. 38, n. 4, p. 902-9013, nov. 1956.

NORKIN, C.C.; WHITE, D.J. Measurement of joint motion: a guide to goniometry. Philadelphia: FA Davis Co; 1995.

NOROUZI-GHEIDARI, N.; ARCHAMBAULT, P.S.; FUNG, J. Effects of robot-assisted therapy on stroke rehabilitation in upper limbs: systematic review and meta-analysis of the literature. Journal of Rehabilitation Research and Development, Baltimore, v. 49, n. 4, p. 479-496, 2012.

NUNES, S.; PEREIRA, C.; SILVA, M.G. Evolução funcional de utentes após AVC nos primeiros seis meses após a lesão. EssFisiOnline, Setúbal, v. 1, n. 3, p. 3-20, 2005.

PAHL, G.; BEITZ, W. Projeto na Engenharia. 6 ed. São Paulo: Edgard Blücher, 2004.

PINELLE. D.; WONG, N.; STACH, T. Heuristic Evaluation for Games: Usability Principles for Video Game Design. In: SIGCHI CONFERECEN ON HUMAN FACTORS IN COMPUTING SYSTEMS, 2008, Florença. Proceedings... Florence: ACM, 2008, p. 14531462.

PORTO, C.C. Exame clínico: bases para a prática médica. Rio de Janeiro: Guanabara Koogan; 2000.

POSTERARO, F. et al. Upper limb spasticity reduction following active training: a robotmediated study in patients with chronic hemiparesis. Journal of Rehabilitation Medicine, Upssala, v. 42, n. 3, p. 279-281, mar. 2010.

PRANGE, G.B. et al. Systematic review of the effect of robot-aided therapy on recovery of the hemiparetic arm after stroke. Journal of Rehabilitation Research and Development, Baltimore, v. 43, n. 2, p. 171-184, mar./abr. 2006.

PUGH, S. Total Design: Integrated Methods for Successful Product Engineering. Wokingham, Addison-Wesley, 1995.

RIBERTO, M. et al. Independência funcional em pessoas com lesões encefálicas adquiridas sob reabilitação ambulatorial. Acta Fisiátrica, São Paulo, v. 14, n. 2, p. 87-94, 2007. 
RIBERTO, M. et al. Validação da versão brasileira da medida de independência funcional. Acta Fisiátrica, São Paulo, v. 11, n. 2, p. 72-76, 2004.

ROCHA, H. V., BARANAUSKAS, M. C. Design e Avaliação de Interfaces HumanoComputador. Campinas: NIED/ UNICAMP, 2003.

SALE, P. et al. Effects of upper limb robot-assisted therapy on motor recovery in subacute stroke patients. Journal of NeuroEngineering and Rehabilitation, v. 11, n. 104, p. 1-8, jun. 2014.

SAMPIERI, R. H.; COLLADO, C. F.; LUCIO, P. B. Metodologia de Pesquisa. São Paulo: McGraw-Hill, 2006.

SANTOS, L.H.O. Arcabouço para construção de jogos ubíquos com foco em reabilitação. 2016. 73f. Dissertação (Mestrado em Informática) - Universidade de Brasília, Brasília, 2016.

SAPOSNIK, G.; MINDY, L.; STROKE OUTCOME RESEARCH CANADA (SORCan) WORKING GROUP. Virtual reality in stroke rehabilitation: a meta-analysis and implication for clinicians. Stroke, Dallas, v. 42, n. 5, p. 1380-1386, maio 2011.

SILVA, J.L.B.; SILVA, P.G.; GAZZALLE, A. Lesões do plexo braquial. Revista da AMRIGS, Porto Alegre, v. 54, n. 3, p. 344-349, jul./set. 2010.

SIMÕES, C.M. Paraplegia: prevalência, etiologia e processo de reabilitação. 2008. 105f. Dissertação (Mestrado em Educação) - Instituto de Educação e Psicologia, Universidade do Minho, 2008.

STRATFORD, P. et al. Assessing disability and change on individual patients: a report of a patient specific measure. Physiotherapy Canada, Toronto, v. 47, n/ 4, p. 258-263, 1995.

ULRICH, K.T.; EPPINGER, S.D. Product design and development. 3rd ed. New York: McGraw-Hill, 2004

URBAN, G. L.; HAUSER, J. R. Design and marketing of new products. 2nd ed. EnglewoodCliffs: Prentice Hall, 1993.

VIEIRA, M.I.C.F.O. A pessoa com AVC: promoção do autocuidado nas AVD. 2013. Dissertação (Mestrado em Enfermagem de Reabilitação) - Escola Superior de Enfermagem de Lisboa, 2013.

VOLPE, B.T.; KREBS, H.I.; HOGAN, N. Is robot-aided sensorimotor training in stroke rehabilitation a realistic option? Current Opinion in Neurology, Philadelphia, v. 14, n. 6, p. 745-752, dez. 2001.

ZIHERL J. et al. Evaluation of upper extremity robot-assistances in subacute and chronic stroke subjects. Journal of NeuroEngineering and Rehabilitation, v. 7, n. 52, p. 1-9, out. 2010. 
APÊNDICES 
APÊNDICE A - PROTOCOLO THINK ALOUD - PENSE ALTO

Nome

Reg. (sujeito)

Data Dominância ( ) D （） E Lado Lesado (quando houver)（）D（）E

Protocolo verbal Think aloud: transcrever as palavras, frases e expressões ditas pelos participantes durante a realização do jogo em uso com o robô MOREw. Colocar em ordem de acontecimento.

$1-$

2-

$3-$

$4-$

$5-$

6-

$7-$

8-

9-

$10-$ 
APÊNDICE B - GONIOMETRIA

Nome

Reg. (sujeito)

Data Dominância ( ) D （）E Lado Lesado ( ) D （）E

Goniometria ativa - hemicorpo afetado

\begin{tabular}{|l|l|l|l|}
\hline Movimento & Ombro & Cotovelo & Punho \\
\hline flexão (0-180) & & & \\
\hline extensão (0-45/50) & & & \\
\hline abdução (0-180) & & ------- & ------ \\
\hline supinação (0-90) & ------- & & ------- \\
\hline pronação (0-90) & ------- & & ------ \\
\hline
\end{tabular}


APÊNDICE C - MEDIDA DE FORÇA MUSCULAR

Nome Reg. (sujeito)

Data Dominância ( ) D ( ) E Lado Lesado ( ) D ( ) E

Força Muscular Manual ativa do hemicorpo lesado

\begin{tabular}{|l|c|c|c|}
\hline Movimento & Ombro & Cotovelo & Punho \\
\hline flexão & & & \\
\hline extensão & & & \\
\hline Abdução & & --------- & ----- \\
\hline Supinação & --------- & & ----- \\
\hline Pronação & --------- & & --- \\
\hline
\end{tabular}

Teste de preensão Palmar Jamar - hemicorpo lesado

\begin{tabular}{|l|l|l|l|l|}
\hline \multicolumn{2}{|l|}{ PREENSÃO } & \multicolumn{1}{|l|}{ Média } \\
\hline Direita & & & & \\
\hline Esquerda & & & & \\
\hline \hline
\end{tabular}




\section{APÊNDICE D - ESCALA FUNCIONAL ESPECÍFICA DO PACIENTE}

\section{Instrução}

Este questionário é útil e pode ser utilizado para quantificar a limitação na realização da atividade pelo paciente (com qualquer condição ortopédica), e assim medir seu resultado funcional. O profissional deve ler e preencher abaixo: Faça-o após coletar a história clínica e antes do exame físico.

Avaliação Inicial:

Vou pedir-lhe para identificar até duas atividades importantes que você é incapaz de fazer ou que está tendo dificuldade, como resultado de seu problema.

Hoje, existem atividades que você é incapaz de fazer ou apresenta dificuldade em realizar por causa de seu problema? (Terapeuta: mostre a escala numérica para o paciente pontuar cada atividade e preencha o quadro abaixo).

Regime específico para o paciente pontuar a atividade (Peça que ele aponte para um número em cada atividade que escolheu):

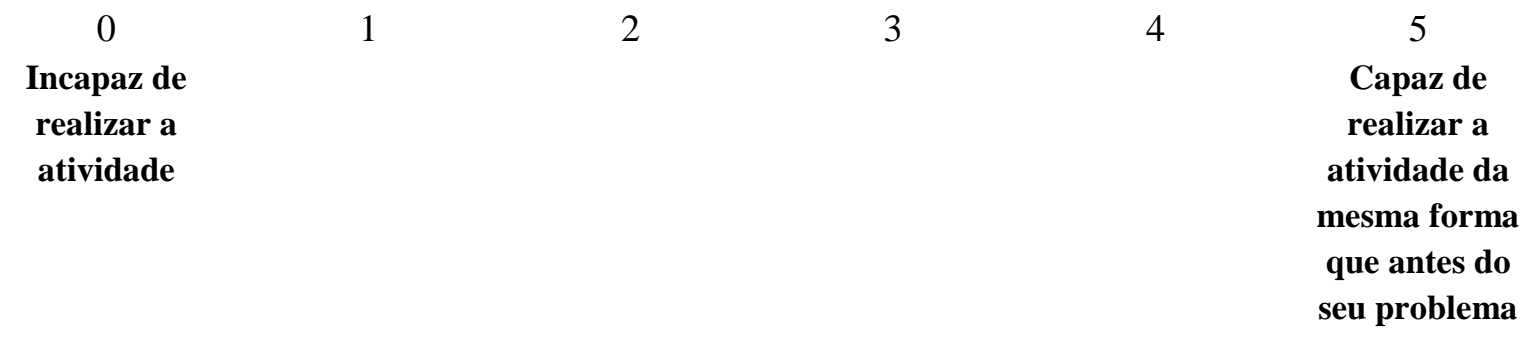

\section{Avaliação de seguimento:}

Quando eu te avaliei no dia (data de avaliação anterior), você me disse que você tinha dificuldade com (ler todas as atividades da lista de uma vez). Hoje, você ainda tem dificuldade com: (ler cada um de cada vez e peça que pontue cada item da lista novamente usando a mesma escala (mostre)?

\section{Pontuação total $=$ soma dos escores de atividade $/$ número de atividades}

Alteração mínima detectável (IC 90\%) para a média de pontuação $=2$ pontos Alteração mínima detectável (IC 90\%) para a atividade único escore $=3$ pontos Desenvolvido por: Stratford, P., Gill, C., Westaway, M., \& Binkley, J. (1995). Assessing disability and change on individual patients: a report of a patient specific measure. Physiotherapy Canada, 47, 258-263. 
Traduzido por Valéria Meirelles Carril Elui, autorizado pela autora Pat Mackee.

ESCALA FUNCIONAL ESPECÍFICA DO PACIENTE

Nome

Reg. (sujeito)

\section{Data}

Dominância ( ) D （）E Lado Lesado ( ) D （） E

\begin{tabular}{|l|l|l|}
\hline \multicolumn{1}{|c|}{ Atividade } & Data & Data \\
\cline { 2 - 3 } & & \\
\hline $\begin{array}{l}\text { 1- Alcançar um copo/garrafa a sua frente em } \\
\text { uma mesa (distancia 10 cm da beirada da } \\
\text { mesa) }\end{array}$ & & \\
\hline $\begin{array}{l}\text { 2- Alcançar um copo/garrafa a sua frente em } \\
\text { uma mesa (distancia 45 cm da beirada da } \\
\text { mesa) }\end{array}$ & & \\
\hline $\begin{array}{l}\text { 3- Alcançar um copo/garrafa do lado em uma } \\
\text { mesa (na beirada da mesa e com uma distância } \\
\text { de 30 cm a partir da lateral do hemicorpo } \\
\text { testado) }\end{array}$ & & \\
\hline $\begin{array}{l}\text { 4- Atividade de escolha do paciente } \\
\text { 5- Atividade de escolha do paciente }\end{array}$ & & \\
\hline
\end{tabular}

\section{Pontuação}

\begin{tabular}{|l|l|}
\hline Atividade & Diferença pontuação \\
\hline $1-$ & \\
\hline $2-$ & \\
\hline $3-$ & \\
\hline $4-$ & \\
\hline $5-$ & \\
\hline Média da pontuação total & \\
\hline
\end{tabular}


APÊNDICE E - MEDIDA DE INDEPENDÊNCIA FUNCIONAL - MIF

Nome

Reg. (sujeito)

Data Dominância ( ) D ( ) E Lado Lesado ( ) D ( ) E

\begin{tabular}{|l|l|l|}
\hline Níveis & $\begin{array}{l}7 \text { Independência completa (em segurança, em } \\
\text { tempo normal) } \\
6 \text { Independência modificada (ajuda técnica) }\end{array}$ & $\begin{array}{l}\text { Sem Ajuda } \\
4 \text { Ajuda Mínima (indivíduo >=75\%) } \\
3 \text { Ajuda Moderada (indivíduo >=50\%) } \\
2 \text { Ajuda Máxima (indivíduo >= 25\%) } \\
1 \text { Ajuda Total (indivíduo }>=0 \%)\end{array}$ \\
\hline
\end{tabular}

\begin{tabular}{|l|l|l|}
\hline AUTOCUIDADO & avaliação _____ & reavaliação_____- \\
\hline A - Alimentação & & \\
\hline B - Higiene pessoal & & \\
\hline C - Banho & & \\
\hline $\begin{array}{l}\text { D - Vestir metade } \\
\text { superior }\end{array}$ & & \\
\hline E - Vestir metade inferior & & \\
\hline $\begin{array}{l}\text { F - Utilização do vaso } \\
\text { sanitário }\end{array}$ & & \\
\hline $\begin{array}{l}\text { CONTROLE DE } \\
\text { ESFINCTRES }\end{array}$ & avaliação _-__- & reavaliação ___- \\
\hline G - Controle de urina & & \\
\hline H - Controle das fezes & & \\
\hline
\end{tabular}




\begin{tabular}{|c|c|c|}
\hline MOBILIDADE & avaliaçãa ______ & reavaliação ______ \\
\hline \multicolumn{3}{|l|}{$\begin{array}{l}\text { I - Leito, cadeira, cadeira de } \\
\text { rodas }\end{array}$} \\
\hline \multicolumn{3}{|l|}{$\mathbf{J}$ - Vaso sanitário } \\
\hline \multicolumn{3}{|l|}{ K - Banheira, chuveiro } \\
\hline LOCOMOÇÃO & avaliação ______ & reavaliação ______ \\
\hline \multicolumn{3}{|l|}{$\begin{array}{l}\mathrm{L} \text {-Marcha/ cadeira de } \\
\text { rodas }\end{array}$} \\
\hline \multicolumn{3}{|l|}{ M- Escadas } \\
\hline COMUNICAÇÃOO & avaliação ___ I & reavaliação \\
\hline \multicolumn{3}{|l|}{ N - Compreensão (a/v) } \\
\hline \multicolumn{3}{|l|}{$\bar{O}-$ Expressão (a/v) } \\
\hline COGNIÇÃO SOCIAL & avaliação ____ & reavaliação ___ I I \\
\hline \multicolumn{3}{|l|}{$\vec{P}$ - Interação social } \\
\hline \multicolumn{3}{|l|}{ Q - Resolução de problemas } \\
\hline \multicolumn{3}{|l|}{$\mathbf{R}$ - Memória } \\
\hline \multicolumn{3}{|l|}{ TOTAL = } \\
\hline $\begin{array}{l}\text { Nota: não deixe nenhum } \\
\text { item em branco: se não } \\
\text { possível de ser testado, } \\
\text { marque } 1 \text {. }\end{array}$ & & \\
\hline
\end{tabular}




\section{APÊNDICE F - QUESTIONÁRIO DE SATISFAÇÃO/DIFICULDADE COM O MOREW}

Nome Reg. (sujeito)

Data Dominância ( ) D （） E Lado Lesado (quando houver) （）D（） E

Este questionário tem o intuito verificar os itens quanto a facilidade/dificuldade, satisfação/insatisfação com o uso do robô MORE-w. Sinta-se à vontade para colocação sugestões, críticas, para que dessa forma possamos aperfeiçoar o robô.

Você deve pontuar de 1 a 4 cada item, onde:

1 = muito bom, fácil, confortável;

2 = um pouco bom, fácil, confortável

3 = um pouco ruim, difícil, desconfortável

4 = muito ruim, difícil, desconfortável

Antes de iniciarmos uma pergunta: Você gosta de jogos ( ) SIM ( ) NÃO TIPO:

Usa ou usou computador ( ) SIM ( ) NÃO

\begin{tabular}{|l|l|l|l|l|}
\hline & 1 & $\mathbf{2}$ & $\mathbf{3}$ & $\mathbf{4}$ \\
\hline Orientações fornecidas antes do jogo & & & & \\
\hline Fixação do braço na manopla & & & & \\
\hline Movimentação da manopla & & & & \\
\hline Esforço para atingir o alvo & & & & \\
\hline Peso do equipamento & & & & \\
\hline Conforto de uso do equipamento & & & & \\
\hline Tempo de realização do jogo & & & & \\
\hline A música existente no jogo & & & & \\
\hline Segurança para realização do jogo & & & & \\
\hline Confiança do uso (inverso ao medo e receio de jogar) & & & \\
\hline
\end{tabular}




\begin{tabular}{|l|l|l|l|l|}
\hline Estimulante/Motivador & & & & \\
\hline Estética/Aparência & & & & \\
\hline Indicação para outra pessoa & & & & \\
\hline Opinião Geral do jogo & & & & \\
\hline
\end{tabular}

1- Jogar causou dor ou piorou alguma dor que já sentia? ( ) sim （ ） não

2- Caso considere difícil, explique as dificuldades encontradas.

3- Você tem sugestão de mudança visando melhorar/facilitar o jogo. 


\section{ESCLARECIDO - FASE 1}

Consentimento formal de Participação no Estudo intitulado "Novas tecnologias robóticas para o tratamento de alterações motoras no membro superior" Pesquisador Responsável: Gabriela Caseiro Almeida Silva. Orientadora: Profa. Dra Valéria Meirelles Carril Elui

\section{Esclarecimento Geral:}

Estamos desenvolvendo um projeto de pesquisa "Novas tecnologias robóticas para o tratamento de alterações motoras no membro superior" e gostaríamos de convidá-lo(a) a participar deste trabalho. Você está sendo convidado(a) a participar deste estudo, que tem por objetivo verificar o funcionamento do equipamento robótico de reabilitação (exercício) utilizando jogos virtuais, que visa ser um complemento a mais no tratamento de reabilitação de pessoas que sofreram lesão de plexo braquial ou da medula.

O trabalho será dividido em duas etapas: $1^{a}$ etapa: visa verificar como você, que não possui dificuldades nos membros superiores consegue utilizar o robô, ou seja, como é o funcionamento e a segurança do mesmo e a $2^{\mathrm{a}}$ etapa, que após verificar essa eficácia e adequarmos o melhor funcionamento do robô será realizado um estudo inserindo-o no processo de reabilitação de sujeitos que apresentam dificuldades em movimentar o membro superior visando ser mais um recursos para auxiliá-los a ganhar o movimento possível e assim terem melhor funcionalidade e qualidade de vida.

Este se refere ao convite para a primeira fase (FASE 1).

Explicação do procedimento:

Você está sendo convidado a vir jogar e usar o MORE-w. Caso aceite e assine esse termo, você poderá vir no horário e dia que for mais conveniente e acordado previamente com os pesquisadores, sem que isto interfira com suas atividades laborais ou de estudo. O robô se encontra no Laboratório de Reabilitação e Robótica e você deverá jogar e responder a um questionário sobre sua opinião e sugestões. Para jogar, o seu antebraço será acoplado ao equipamento robótico através de velcro, será calibrado e dado as orientações do funcionamento para o jogo.

Você jogará por 10 minutos, e deverá verbalizar as dúvidas ou dificuldades e facilidades (Think aloud). Tudo será anotado e depois levado em consideração para realizarmos as modificações que se fizerem necessárias. Todo procedimento deve durar em torno de 30 minutos. Você também nos falará das dificuldades encontradas e das sugestões para melhoria. Se houver sugestão e necessidade de modificação, solicitamos que você retorne para testar novamente e dar sua opinião novamente. Participando você estará nos ajudando a avaliar a eficácia e segurança de um novo equipamento robótico com jogos, para então ser testado em indivíduos/usuários com diferentes dificuldades de movimentação do membro superior.

Para isso você deve estar ciente de que:

1. Sua participação é voluntária e sua recusa não implicará em nenhum tipo de prejuízo às suas atividades laborais ou de estudo;

2. As informações contidas durante a coleta de dados, poderão ser utilizadas para fins didáticos e em eventos ou trabalhos científicos, mas não serão expostos de forma que o (a) identifique e sua identidade será sempre preservada; desta forma garantimos sua privacidade e o sigilo quanto às informações prestadas;

3. Os riscos à sua saúde são mínimos, como ligeiro cansaço em realizar os jogos, ficar motivado e ter que parar, mas na eventualidade de ocorrência você tem direito a indenização conforme as leis vigentes no país. 
4. Você é livre para se recusar a participar, desistir de participar deste trabalho, a qualquer momento, sem punição e sem prejuízo.

5. Você não terá nenhum ganho monetário por participar do estudo, não havendo formas de ressarcimento das despesas (exemplo: transporte e alimentação).

6. Você tem direito a indenização conforme as leis vigentes no país, caso ocorra dano decorrente de participação na pesquisa;

7. Os resultados da pesquisa serão tornados públicos, sejam eles favoráveis ou não. Garantimos que quaisquer dúvidas que surjam antes, durante ou posteriormente aos procedimentos desta pesquisa serão devidamente esclarecidas pelos pesquisadores.

8. Você receberá uma via (e não uma cópia) do Termo de Consentimento Livre e Esclarecido, assinado e rubricado em todas as páginas pelo pesquisador.

9. Você pode entrar em contato, para maiores esclarecimentos, no Comitê de Ética em Pesquisa do Hospital das Clínicas e da Faculdade de Medicina de Ribeirão Preto (16) 3602-2228 para dúvidas éticas.

Para questões e/ou dúvidas relacionadas a este estudo, contate:

\section{Gabriela Caseiro Almeida Silva}

Fone: (16) 3602-4417 e-mail: velui @fmrp.usp.br / CEP-HC : (16) 3602-2228

Declaro que, após convenientemente esclarecido pelo pesquisador e ter entendido o que me foi explicado, consinto em participar do presente Protocolo de Pesquisa. Recebi uma cópia deste termo e tive a possibilidade de lê-lo, com o qual concordo.

São Carlos, de de 20

Nome do participante:

Assinatura:

Nome do pesquisador:

Assinatura: 


\section{ESCLARECIDO - FASE 2}

Consentimento formal de Participação no Estudo intitulado "Novas tecnologias robóticas para o tratamento de alterações motoras no membro superior" Pesquisador Responsável: Gabriela Caseiro Almeida Silva. Orientadora: Profa. Dra Valéria Meirelles Carril Elui

\section{Esclarecimento Geral:}

Estamos desenvolvendo um projeto de pesquisa "Novas tecnologias robóticas para o tratamento de alterações motoras no membro superior" e gostaríamos de convidá-lo(a) a participar deste trabalho. Você está sendo convidado(a) a participar deste estudo, que tem por objetivo verificar o funcionamento do equipamento robótico de reabilitação (exercício) utilizando jogos virtuais, que visa ser um complemento a mais no tratamento de reabilitação de pessoas que sofreram lesão de plexo braquial ou da medula. Este é um recurso complementar (a mais) ao tratamento de reabilitação que já recebe aqui no CER. O robô já foi testado quanto ao funcionamento e segurança com indivíduos sem alteração de movimento no membro superior. O trabalho está dividido em duas fases: fase 1: esta fase já aconteceu e visou verificar o funcionamento robô, e a fase 2 (que é esta que você pode participar) para verificarmos o funcionamento do robô com pessoas que possuem alterações motoras, dificuldades para movimentação dos braços. Na fase 2 terá 2 etapas, etapa 1 para você conhecer o jogo e etapa 2 para usá-lo toda semana com duração de 3 meses no total.

Este convite se refere à FASE 2.

Explicação do procedimento:

Após explicarmos o que o robô faz e o seu aceite em participar, durante o seu tratamento já agendado será realizado uma avaliação mais minuciosa de seu membro superior através da goniometria de ombro, cotovelo e punho, usando o goniômetro (tipo régua) para fazer essas medidas. Também será verificada a força muscular (ver os movimentos que consegue fazer). Você também responderá a algumas perguntas antes de usar o equipamento robótico como por exemplo: o que é importante para você que não consegue realizar, se gosta de jogos e que tipo de jogos, se já usou ou usa computador. Depois usará o robô e jogará o jogo selecionado pelo terapeuta. Esse procedimento deve durar em torno de 30 minutos. Enquanto você utilizar o equipamento serão anotadas todas as suas dúvidas, frases e palavras ditas com o uso. Você também nos falará das dificuldades/facilidades encontradas e das necessidades para melhoria. Cada vez que você ou o terapeuta solicitarem mudanças no robô MORE-w, as modificações serão feitas e você retornará para realizar o mesmo procedimento (jogar) novamente. Nessa etapa você deverá comparecer no máximo 3 vezes. Também faremos fotografias sobre a posição (ergonomia) do robô MORE-w.

Participando você estará nos ajudando a avaliar a eficácia e segurança de um novo equipamento robótico com jogos para ser testado com um grupo maior de pessoas e com diferentes dificuldades de movimentação do membro superior. Após esses ajustes você utilizará, logo após sua sessão de terapia ocupacional, o robô 1x por semana durante 3 meses. No início e no final desses três meses nós faremos as avaliações citadas acima (goniometria, teste de força e perguntas se você consegue ou não fazer algumas atividades). Para isso você deve estar ciente de que:

1. Sua participação é voluntária e sua recusa não implicará em prejuízos ao seu atendimento neste ambulatório ou qualquer outro deste hospital ou de qualquer um de seus familiares; 
2. As informações contidas nas avaliações, poderão ser utilizadas para fins didáticos e em eventos ou trabalhos científicos, mas não serão expostos de forma que o (a) identifique e sua identidade será sempre preservada; desta forma garantimos sua privacidade e o sigilo quanto às informações prestadas;

3. Os riscos à sua saúde são mínimos, como ligeiro cansaço ao responder aos questionários ou jogar, mas na eventualidade de ocorrência você tem direito a indenização conforme as leis vigentes no país.

4. Você é livre para se recusar a participar, desistir de participar deste trabalho, a qualquer momento, sem punição ou prejuízo no seu tratamento.

5. Você não terá nenhum ganho monetário por participar do estudo, não havendo formas de ressarcimento das despesas (exemplo: transporte e alimentação).

6. Você tem direito a indenização conforme as leis vigentes no país, caso ocorra dano decorrente de participação na pesquisa;

7. Os resultados da pesquisa serão tornados públicos, sejam eles favoráveis ou não. Garantimos que quaisquer dúvidas que surjam antes, durante ou posteriormente aos procedimentos desta pesquisa serão devidamente esclarecidas pelos pesquisadores.

8. Você receberá uma via (e não uma cópia) do Termo de Consentimento Livre e Esclarecido, assinado e rubricado em todas as páginas pelo pesquisador.

9. Você pode entrar em contato, para maiores esclarecimentos, no Comitê de Ética em Pesquisa do Hospital das Clínicas e da Faculdade de Medicina de Ribeirão Preto (16) 3602-2228 para dúvidas éticas.

Para questões e/ou dúvidas relacionadas a este estudo, contate: Gabriela Caseiro Almeida Silva

Fone: (16) 3602-4417 e-mail: velui@ fmrp.usp.br / CEP-HC : (16) 3602-2228

Declaro que, após convenientemente esclarecido pelo pesquisador e ter entendido o que me foi explicado, consinto em participar do presente Protocolo de Pesquisa. Recebi uma cópia deste termo e tive a possibilidade de lê-lo, com o qual concordo.

Nome do participante:

Assinatura:

Nome do pesquisador:

Assinatura:

Ribeirão Preto - SP, de de 20 


\section{APÊNDICE I - CATEGORIAS DE ANÁLISE DO PROTOCOLO THINK ALOUD}

A- Categorias de análise do protocolo Think Aloud Fase 1 - Teste 1

\begin{tabular}{lll} 
Frases Categorizadas & $\%$ de aparecimento & Mudanças realizadas \\
\hline $\begin{array}{l}\text { Queda da noz: ajustes na } \\
\text { velocidade e na localização } \\
\text { espacial (monótono, sem } \\
\text { variações) }\end{array}$ & $90 \%$ & Ajustes no algoritmo \\
\hline $\begin{array}{l}\text { Amplitude de flexão/extensão } \\
\text { de punho (extrema, causa dor) }\end{array}$ & $80 \%$ & \\
\hline $\begin{array}{l}\text { Layout do jogo: tamanho da } \\
\text { tela, quantidade de estímulos } \\
\text { distratores (necessário } \\
\text { diminuir) }\end{array}$ & $70 \%$ & Ajustes no algoritmo \\
\hline $\begin{array}{l}\text { Posicionamento do braço no } \\
\text { robô (ruim) }\end{array}$ & $40 \%$ & Ajustes no jogo \\
& & \\
& & $\begin{array}{l}\text { Confecção de mesa } \\
\text { com regulagem de } \\
\text { altura, melhor fixação } \\
\text { na manopla para maior } \\
\text { conforto e estabilidade } \\
\text { - troca de material) }\end{array}$ \\
\hline $\begin{array}{l}\text { Sensibilidade do esquilo em } \\
\text { variações de movimento } \\
\text { (muito sensível) }\end{array}$ & $40 \%$ & $\begin{array}{l}\text { Ajustes na } \\
\text { programação }\end{array}$ \\
\hline $\begin{array}{l}\text { Falta de botão de emergência } \\
10 \%\end{array}$ & & $\begin{array}{l}\text { Confecção do botão de } \\
\text { emergência }\end{array}$ \\
\hline
\end{tabular}

B- Categorias de análise do protocolo Think Aloud Fase 1 - Teste 2

\begin{tabular}{lcl}
\hline Frases Categorizadas & \% de aparecimento & Mudanças realizadas \\
Dinâmico, estimulante & $100 \%$ & $\begin{array}{l}\text { Sem necessidades de } \\
\text { ajustes }\end{array}$ \\
$\begin{array}{l}\text { Nenhuma necessidade de } \\
\text { outros ajustes }\end{array}$ & $100 \%$ & $\begin{array}{l}\text { Sem necessidades de } \\
\text { ajustes }\end{array}$ \\
\hline
\end{tabular}




\section{APÊNDICE J - QUESTIONÁRIO SATISFAÇÃO/DIFICULDADE COM O USO DO ROBÔ MOREW FASE 2 ETAPA 1}

SUJEITO 1 - avaliação etapa 1

\begin{tabular}{|l|l|l|l|l|}
\hline & $\mathbf{1}$ & $\mathbf{2}$ & $\mathbf{3}$ & $\mathbf{4}$ \\
\hline Orientações fornecidas antes do jogo & & $\mathrm{X}$ & & \\
\hline Fixação do braço na manopla & & $\mathrm{X}$ & & \\
\hline Movimentação da manopla & & $\mathrm{X}$ & & \\
\hline Esforço para atingir o alvo & $\mathrm{X}$ & & \\
\hline Conforto de uso do equipamento & $\mathrm{X}$ & & & \\
\hline Tempo de realização do jogo & $\mathrm{X}$ & & & \\
\hline A música existente no jogo & $\mathrm{X}$ & & & \\
\hline Segurança para realização do jogo & $\mathrm{X}$ & & & \\
\hline Confiança do uso (inverso ao medo e receio de jogar) & $\mathrm{X}$ & & & \\
\hline Estimulante/Motivador & & $\mathrm{X}$ & & \\
\hline Estética/Aparência & $\mathrm{X}$ & & & \\
\hline Indicação para outra pessoa & $\mathrm{X}$ & & & \\
\hline Opinião Geral do jogo & & & \\
\hline
\end{tabular}

SUJEITO 1 - reavaliação etapa 2

\begin{tabular}{|l|l|l|l|l|}
\hline & 1 & $\mathbf{2}$ & $\mathbf{3}$ & $\mathbf{4}$ \\
\hline Orientações fornecidas antes do jogo & $\mathrm{X}$ & & & \\
\hline Fixação do braço na manopla & & & $\mathrm{X}$ & \\
\hline Movimentação da manopla & & & $\mathrm{X}$ & \\
\hline Esforço para atingir o alvo & & $\mathrm{X}$ & & \\
\hline Conforto de uso do equipamento & $\mathrm{X}$ & & & \\
\hline Tempo de realização do jogo & $\mathrm{X}$ & & & \\
\hline
\end{tabular}




\begin{tabular}{|l|l|l|l|l|}
\hline A música existente no jogo & $\mathrm{X}$ & & & \\
\hline Segurança para realização do jogo & $\mathrm{X}$ & & & \\
\hline Confiança do uso (inverso ao medo e receio de jogar) & $\mathrm{X}$ & & & \\
\hline Estimulante/Motivador & $\mathrm{X}$ & & & \\
\hline Estética/Aparência & & $\mathrm{X}$ & & \\
\hline Indicação para outra pessoa & $\mathrm{X}$ & & & \\
\hline Opinião Geral do jogo & $\mathrm{X}$ & & & \\
\hline
\end{tabular}

SUJEITO 2 - avaliação etapa 1

\begin{tabular}{|l|l|l|l|l|}
\hline & $\mathbf{1}$ & $\mathbf{2}$ & $\mathbf{3}$ & $\mathbf{4}$ \\
\hline Orientações fornecidas antes do jogo & $\mathrm{X}$ & & & \\
\hline Fixação do braço na manopla & & $\mathrm{X}$ & & \\
\hline Movimentação da manopla & & $\mathrm{X}$ & & \\
\hline Esforço para atingir o alvo & & $\mathrm{X}$ & & \\
\hline Conforto de uso do equipamento & $\mathrm{X}$ & & & \\
\hline Tempo de realização do jogo & $\mathrm{X}$ & & & \\
\hline A música existente no jogo & $\mathrm{X}$ & & & \\
\hline Segurança para realização do jogo & $\mathrm{X}$ & & & \\
\hline Confiança do uso (inverso ao medo e receio de jogar) & $\mathrm{X}$ & & & \\
\hline Estimulante/Motivador & $\mathrm{X}$ & & & \\
\hline Estética/Aparência & $\mathrm{X}$ & & & \\
\hline Indicação para outra pessoa & $\mathrm{X}$ & & & \\
\hline Opinião Geral do jogo & $\mathrm{X}$ & & & \\
\hline
\end{tabular}

SUJEITO 2 - reavaliação etapa 2

\begin{tabular}{|l|l|l|l|l|}
\hline & 1 & 2 & 3 & 4 \\
\hline Orientações fornecidas antes do jogo & $X$ & & & \\
\hline
\end{tabular}




\begin{tabular}{|c|c|c|}
\hline Fixação do braço na manopla & & $\mathrm{X}$ \\
\hline Movimentação da manopla & & $\mathrm{X}$ \\
\hline Esforço para atingir o alvo & & $\mathrm{X}$ \\
\hline Conforto de uso do equipamento & & $\mathrm{X}$ \\
\hline Tempo de realização do jogo & $\mathrm{X}$ & \\
\hline A música existente no jogo & $\mathrm{X}$ & \\
\hline Segurança para realização do jogo & $\mathrm{X}$ & \\
\hline Confiança do uso (inverso ao medo e receio de jogar) & $\mathrm{X}$ & \\
\hline Estimulante/Motivador & $\mathrm{X}$ & \\
\hline Estética/Aparência & $\mathrm{X}$ & \\
\hline Indicação para outra pessoa & $\mathrm{X}$ & \\
\hline Opinião Geral do jogo & $\mathrm{X}$ & \\
\hline
\end{tabular}

SUJEITO 3 - avaliação etapa 1

\begin{tabular}{|l|l|l|l|l|}
\hline & \multicolumn{1}{|l|}{$\mathbf{3}$} & $\mathbf{2}$ & $\mathbf{3}$ & $\mathbf{4}$ \\
\hline Orientações fornecidas antes do jogo & $\mathrm{X}$ & & & \\
\hline Fixação do braço na manopla & $\mathrm{X}$ & & & \\
\hline Movimentação da manopla & $\mathrm{X}$ & & & \\
\hline Esforço para atingir o alvo & $\mathrm{X}$ & & & \\
\hline Conforto de uso do equipamento & $\mathrm{X}$ & & & \\
\hline Tempo de realização do jogo & & $\mathrm{X}$ & & \\
\hline A música existente no jogo & $\mathrm{X}$ & & & \\
\hline Segurança para realização do jogo & $\mathrm{X}$ & & & \\
\hline Confiança do uso (inverso ao medo e receio de jogar) & $\mathrm{X}$ & & & \\
\hline Estimulante/Motivador & $\mathrm{X}$ & & & \\
\hline Estética/Aparência & $\mathrm{X}$ & & & \\
\hline
\end{tabular}




\begin{tabular}{|l|l|l|l|l|}
\hline Indicação para outra pessoa & $X$ & & & \\
\hline Opinião Geral do jogo & $X$ & & & \\
\hline
\end{tabular}

SUJEITO 3 - reavaliação etapa 2

\begin{tabular}{|l|l|l|l|l|}
\hline & $\mathbf{2}$ & $\mathbf{3}$ & $\mathbf{4}$ \\
\hline Orientações fornecidas antes do jogo & $\mathrm{X}$ & & & \\
\hline Fixação do braço na manopla & & & $\mathrm{X}$ & \\
\hline Movimentação da manopla & & $\mathrm{X}$ & \\
\hline Esforço para atingir o alvo & & & $\mathrm{X}$ & \\
\hline Conforto de uso do equipamento & & & $\mathrm{X}$ & \\
\hline Tempo de realização do jogo & & $\mathrm{X}$ & & \\
\hline A música existente no jogo & $\mathrm{X}$ & & & \\
\hline Segurança para realização do jogo & $\mathrm{X}$ & & & \\
\hline Confiança do uso (inverso ao medo e receio de jogar) & $\mathrm{X}$ & & & \\
\hline Estimulante/Motivador & $\mathrm{X}$ & & & \\
\hline Estética/Aparência & $\mathrm{X}$ & & & \\
\hline Indicação para outra pessoa & $\mathrm{X}$ & & & \\
\hline Opinião Geral do jogo & $\mathrm{X}$ & & & \\
\hline
\end{tabular}

SUJEITO 4 - avaliação etapa 1

\begin{tabular}{|l|l|l|l|l|}
\hline & 1 & $\mathbf{2}$ & $\mathbf{3}$ & $\mathbf{4}$ \\
\hline Orientações fornecidas antes do jogo & & $\mathrm{X}$ & & \\
\hline Fixação do braço na manopla & & $\mathrm{X}$ & & \\
\hline Movimentação da manopla & & $\mathrm{X}$ & & \\
\hline Esforço para atingir o alvo & & $\mathrm{X}$ & & \\
\hline Conforto de uso do equipamento & & $\mathrm{X}$ & & \\
\hline Tempo de realização do jogo & & $\mathrm{X}$ & & \\
\hline
\end{tabular}




\begin{tabular}{|l|l|l|l|l|}
\hline A música existente no jogo & $\mathrm{X}$ & & & \\
\hline Segurança para realização do jogo & $\mathrm{X}$ & & & \\
\hline Confiança do uso (inverso ao medo e receio de jogar) & $\mathrm{X}$ & & & \\
\hline Estimulante/Motivador & $\mathrm{X}$ & & & \\
\hline Estética/Aparência & & $\mathrm{X}$ & & \\
\hline Indicação para outra pessoa & $\mathrm{X}$ & & & \\
\hline Opinião Geral do jogo & & $\mathrm{X}$ & & \\
\hline
\end{tabular}

SUJEITO 4 - reavaliação etapa 2

\begin{tabular}{|l|l|l|l|l|}
\hline & $\mathbf{1}$ & $\mathbf{2}$ & $\mathbf{3}$ & $\mathbf{4}$ \\
\hline Orientações fornecidas antes do jogo & & $\mathrm{X}$ & & \\
\hline Fixação do braço na manopla & & & $\mathrm{X}$ & \\
\hline Movimentação da manopla & & $\mathrm{X}$ & & \\
\hline Esforço para atingir o alvo & & $\mathrm{X}$ & & \\
\hline Conforto de uso do equipamento & & $\mathrm{X}$ & & \\
\hline Tempo de realização do jogo & $\mathrm{X}$ & & & \\
\hline A música existente no jogo & $\mathrm{X}$ & & & \\
\hline Segurança para realização do jogo & $\mathrm{X}$ & & & \\
\hline Confiança do uso (inverso ao medo e receio de jogar) & $\mathrm{X}$ & & & \\
\hline Estimulante/Motivador & & $\mathrm{X}$ & & \\
\hline Estética/Aparência & $\mathrm{X}$ & & & \\
\hline Indicação para outra pessoa & & $\mathrm{X}$ & & \\
\hline Opinião Geral do jogo & & & \\
\hline
\end{tabular}

SUJEITO 5 - avaliação etapa 1

\begin{tabular}{|l|l|l|l|l|}
\hline & 1 & 2 & 3 & 4 \\
\hline Orientações fornecidas antes do jogo & & $X$ & & \\
\hline
\end{tabular}




\begin{tabular}{|l|l|l|l|l|}
\hline Fixação do braço na manopla & & X & & \\
\hline Movimentação da manopla & & X & & \\
\hline Esforço para atingir o alvo & & X & & \\
\hline Conforto de uso do equipamento & & $X$ & & \\
\hline Tempo de realização do jogo & $X$ & & & \\
\hline A música existente no jogo & & $X$ & & \\
\hline Segurança para realização do jogo & $X$ & & & \\
\hline Confiança do uso (inverso ao medo e receio de jogar) & $X$ & & & \\
\hline Estimulante/Motivador & $X$ & & & \\
\hline Estética/Aparência & $X$ & & & \\
\hline Indicação para outra pessoa & $X$ & & & \\
\hline Opinião Geral do jogo & $X$ & & & \\
\hline
\end{tabular}

SUJEITO 5 - reavaliação etapa 2

\begin{tabular}{|l|l|l|l|l|}
\hline & $\mathbf{1}$ & $\mathbf{2}$ & $\mathbf{3}$ & $\mathbf{4}$ \\
\hline Orientações fornecidas antes do jogo & & $\mathrm{X}$ & & \\
\hline Fixação do braço na manopla & & & $\mathrm{X}$ & \\
\hline Movimentação da manopla & & $\mathrm{X}$ & & \\
\hline Esforço para atingir o alvo & & $\mathrm{X}$ & & \\
\hline Conforto de uso do equipamento & & $\mathrm{X}$ & & \\
\hline Tempo de realização do jogo & $\mathrm{X}$ & & & \\
\hline A música existente no jogo & & & $\mathrm{X}$ & \\
\hline Segurança para realização do jogo & $\mathrm{X}$ & & & \\
\hline Confiança do uso (inverso ao medo e receio de jogar) & $\mathrm{X}$ & & & \\
\hline Estimulante/Motivador & $\mathrm{X}$ & & & \\
\hline Estética/Aparência & $\mathrm{X}$ & & & \\
\hline
\end{tabular}


Indicação para outra pessoa

Opinião Geral do jogo

\begin{tabular}{|l|l|l|l|}
\hline$X$ & & & \\
\hline$X$ & & & \\
\hline
\end{tabular}


APÊNDICE K - PROTOCOLO DE AVALIAÇÃO

SUJEITO 1 - MIF

\begin{tabular}{|c|c|c|c|c|c|}
\hline AUTOCUIDADO & avaliação & reavaliação & COMUNICAÇÃO & avaliação & reavaliação \\
\hline A - Alimentação & 6 & 6 & N - Compreensão & 7 & 7 \\
\hline B - Higiene pessoal & 6 & 6 & $\bar{O}$ - Expressão & 7 & 7 \\
\hline C-Banho & 6 & 6 & $\begin{array}{l}\text { COGNIÇÃO } \\
\text { SOCIAL }\end{array}$ & avaliação & reavaliação \\
\hline $\begin{array}{c}\text { D - Vestir metade } \\
\text { superior }\end{array}$ & 6 & 6 & P - Interação social & 7 & 7 \\
\hline $\begin{array}{c}\mathbf{E}-\text { Vestir metade } \\
\text { inferior }\end{array}$ & 6 & 6 & $\begin{array}{c}Q-\text { Resolução de } \\
\text { problemas }\end{array}$ & 7 & 7 \\
\hline $\begin{array}{c}\text { F - Utilização do vaso } \\
\text { sanitário }\end{array}$ & 6 & 6 & $\mathbf{R}$-Memória & 7 & 7 \\
\hline $\begin{array}{l}\text { CONTROLE DE } \\
\text { ESFINCTERES }\end{array}$ & avaliação & reavaliação & TOTAL = & 120 & 120 \\
\hline G - Controle de urina & 7 & 7 & & & \\
\hline $\begin{array}{c}\mathrm{H}-\mathrm{Controle} \mathrm{das} \\
\text { fezes }\end{array}$ & 7 & 7 & & & \\
\hline MOBILIDADE & avaliação _ & reavaliação & & & \\
\hline $\begin{array}{l}\text { I - Leito, cadeira, } \\
\text { cadeira de rodas }\end{array}$ & 7 & 7 & & & \\
\hline J - Vaso sanitário & 7 & 7 & & & \\
\hline $\begin{array}{l}\text { K - Banheira, } \\
\text { chuveiro }\end{array}$ & 7 & 7 & & & \\
\hline LOCOMOÇÃO & avaliação & reavaliação & & & \\
\hline $\begin{array}{c}\mathrm{L} \text { - Marcha/ cadeira } \\
\text { de rodas }\end{array}$ & 7 & 7 & & & \\
\hline M - Escadas & 7 & 7 & & & \\
\hline
\end{tabular}

\section{SUJEITO 1 - Escala Funcional Específica do Paciente}

\begin{tabular}{|c|c|c|}
\hline Atividade & Aval. & Reaval. \\
\hline $\begin{array}{l}\text { 1- Alcançar um copo/garrafa a sua frente em } \\
\text { uma mesa (distancia } 10 \mathrm{~cm} \text { da beirada da } \\
\text { mesa) }\end{array}$ & 3 & 4 \\
\hline
\end{tabular}




\begin{tabular}{|l|l|l|}
\hline $\begin{array}{l}\text { 2- Alcançar um copo/garrafa a sua frente } \\
\text { em uma mesa (distancia } 45 \mathrm{~cm} \text { da beirada } \\
\text { da mesa) }\end{array}$ & 3 & 4 \\
\hline $\begin{array}{l}\text { 3- Alcançar um copo/garrafa do lado em } \\
\text { uma mesa (na beirada da mesa e com uma } \\
\text { distância de } 30 \mathrm{~cm} \text { a partir da lateral do } \\
\text { corpo testado) }\end{array}$ & 3 & 4 \\
\hline 4- Erguer o braço no armário acima da pia & 1 & 1 \\
\hline 5- Levar copo à boca com as duas mãos & 1 & 1 \\
\hline Total & 2,2 & 2,8 \\
\hline
\end{tabular}

SUJEITO 2 - MIF

\begin{tabular}{|c|c|c|c|c|c|}
\hline AUTOCUIDADO & avaliação & reavaliação & COMUNICAÇÃO & avaliação & reavaliação \\
\hline A - Alimentação & 6 & 6 & N - Compreensão & 7 & 7 \\
\hline B - Higiene pessoal & 7 & 7 & O - Expressão & 7 & 7 \\
\hline C-Banho & 7 & 7 & $\begin{array}{l}\text { COGNIÇÃO } \\
\text { SOCIAL }\end{array}$ & avaliação & reavaliação \\
\hline $\begin{array}{c}\text { D - Vestir metade } \\
\text { superior }\end{array}$ & 7 & 7 & P - Interação social & 7 & 7 \\
\hline $\begin{array}{c}\text { E- Vestir metade } \\
\text { inferior }\end{array}$ & 7 & 7 & $\begin{array}{c}\text { Q - Resolução de } \\
\text { problemas }\end{array}$ & 7 & 7 \\
\hline $\begin{array}{c}\text { F - Utilização do vaso } \\
\text { sanitário }\end{array}$ & 7 & 7 & $\mathbf{R}$ - Memória & 7 & 7 \\
\hline $\begin{array}{l}\text { CONTROLE DE } \\
\text { ESFINCTERES }\end{array}$ & avaliação & reavaliação & TOTAL = & 125 & 125 \\
\hline G - Controle de urina & 7 & 7 & & & \\
\hline $\begin{array}{c}\mathrm{H}-\mathrm{Controle} \mathrm{das} \\
\text { fezes }\end{array}$ & 7 & 7 & & & \\
\hline MOBILIDADE & avaliação _ & reavaliação & & & \\
\hline $\begin{array}{l}\text { I - Leito, cadeira, } \\
\text { cadeira de rodas }\end{array}$ & 7 & 7 & & & \\
\hline J - Vaso sanitário & 7 & 7 & & & \\
\hline
\end{tabular}




\begin{tabular}{|c|c|c|c|}
\hline $\begin{array}{c}\text { K - Banheira, } \\
\text { chuveiro }\end{array}$ & 7 & 7 & \\
\hline LOCOMOÇÃo & avaliação & reavaliação & \\
\hline $\begin{array}{c}\text { L- Marcha/ cadeira } \\
\text { de rodas }\end{array}$ & 7 & 7 & \\
\hline M- Escadas & 7 & 7 & \\
\hline
\end{tabular}

\section{SUJEITO 2 - Escala Funcional Específica do Paciente}

\begin{tabular}{|l|l|l|}
\hline \multicolumn{1}{|c|}{ Atividade } & Aval. & Reaval. \\
\hline $\begin{array}{l}\text { 2- Alcançar um copo/garrafa a sua frente em } \\
\text { uma mesa (distancia 10 cm da beirada da } \\
\text { mesa) }\end{array}$ & 4 & 5 \\
\hline $\begin{array}{l}\text { 2- Alcançar um copo/garrafa a sua frente } \\
\text { em uma mesa (distancia 45 cm da beirada } \\
\text { da mesa) }\end{array}$ & 3 & 4 \\
\hline $\begin{array}{l}\text { 3- Alcançar um copo/garrafa do lado em } \\
\text { uma mesa (na beirada da mesa e com uma } \\
\text { distância de 30 cm a partir da lateral do } \\
\text { corpo testado) }\end{array}$ & 3 & 4 \\
\hline 4- Arrumar cabelo/boné com mão esquerda & 0 & 1 \\
\hline 5- Cortar alimento sem o uso de tábua adaptada & 0 & 1 \\
\hline Total & 2,0 & 3,0 \\
\hline
\end{tabular}

SUJEITO 3 - MIF

\begin{tabular}{|c|c|c|c|c|c|}
\hline AUTOCUIDADO & avaliação & reavaliação & COMUNICAÇão & avaliação & reavaliação \\
\hline A - Alimentação & 6 & 6 & N - Compreensão & 7 & 7 \\
\hline B - Higiene pessoal & 6 & 6 & O- Expressão & 7 & 7 \\
\hline C - Banho & 6 & 6 & $\begin{array}{c}\text { COGNIÇÃo } \\
\text { SOCIAL }\end{array}$ & avaliação & reavaliação \\
\hline $\begin{array}{c}\text { D - Vestir metade } \\
\text { superior }\end{array}$ & 6 & 6 & P - Interação social & 7 & 7 \\
\hline $\begin{array}{c}\text { E - Vestir metade } \\
\text { inferior }\end{array}$ & 6 & 6 & $\begin{array}{c}\text { Q - Resolução de } \\
\text { problemas }\end{array}$ & 7 & 7 \\
\hline
\end{tabular}




\begin{tabular}{|c|c|c|c|c|c|}
\hline $\begin{array}{c}\text { F - Utilização do vaso } \\
\text { sanitário }\end{array}$ & 7 & 7 & $\mathbf{R}$ - Memória & 7 & 7 \\
\hline $\begin{array}{l}\text { CONTROLE DE } \\
\text { ESFINCTERES }\end{array}$ & avaliação & reavaliação & TOTAL $=$ & 121 & 121 \\
\hline G - Controle de urina & 7 & 7 & & & \\
\hline $\begin{array}{c}\mathrm{H}-\text { Controle das } \\
\text { fezes }\end{array}$ & 7 & 7 & & & \\
\hline MOBILIDADE & avaliação _ & reavaliação & & & \\
\hline $\begin{array}{l}\text { I - Leito, cadeira, } \\
\text { cadeira de rodas }\end{array}$ & 7 & 7 & & & \\
\hline J - Vaso sanitário & 7 & 7 & & & \\
\hline $\begin{array}{l}\mathbf{K}-\text { Banheira } \\
\text { chuveiro }\end{array}$ & 7 & 7 & & & \\
\hline LOCOMOÇÃO & avaliação & reavaliação & & & \\
\hline $\begin{array}{c}\mathrm{L} \text { - Marcha/ cadeira } \\
\text { de rodas }\end{array}$ & 7 & 7 & & & \\
\hline M - Escadas & 7 & 7 & & & \\
\hline
\end{tabular}

\section{SUJEITO 3 - Escala Funcional Específica do Paciente}

\begin{tabular}{|l|l|l|}
\hline \multicolumn{1}{|c|}{ Atividade } & Aval. & Reaval. \\
\hline $\begin{array}{l}\text { 3- Alcançar um copo/garrafa a sua frente em } \\
\text { uma mesa (distancia 10 cm da beirada da } \\
\text { mesa) }\end{array}$ & 4 & 4 \\
\hline $\begin{array}{l}\text { 2- Alcançar um copo/garrafa a sua frente } \\
\text { em uma mesa (distancia 45 cm da beirada } \\
\text { da mesa) }\end{array}$ & 4 & 4 \\
\hline $\begin{array}{l}\text { 3- Alcançar um copo/garrafa do lado em } \\
\text { uma mesa (na beirada da mesa e com uma } \\
\text { distância de 30 cm a partir da lateral do } \\
\text { corpo testado) }\end{array}$ & 4 & 4 \\
\hline 4- Erguer o braço no armário acima da pia & 0 & 0 \\
\hline 5- Levar copo à boca com as duas mãos & 0 & 0 \\
\hline Total & 2,4 & 2,4 \\
\hline
\end{tabular}


SUJEITO 4 - MIF

\begin{tabular}{|c|c|c|c|c|c|}
\hline AUTOCUIDADO & avaliação & reavaliação & COMUNICAÇÃO & avaliação & reavaliação \\
\hline A - Alimentação & 5 & 5 & N-Compreensão & 7 & 7 \\
\hline B - Higiene pessoal & 4 & 4 & O - Expressão & 7 & 7 \\
\hline C-Banho & 2 & 2 & $\begin{array}{l}\text { COGNIÇÃO } \\
\text { SOCIAL }\end{array}$ & avaliação & reavaliação \\
\hline $\begin{array}{c}\text { D - Vestir metade } \\
\text { superior }\end{array}$ & 4 & 4 & P - Interação social & 7 & 7 \\
\hline $\begin{array}{c}\mathbf{E}-\begin{array}{l}\text { Vestir metade } \\
\text { inferior }\end{array} \\
\text { a }\end{array}$ & 1 & 1 & $\begin{array}{c}\text { Q - Resolução de } \\
\text { problemas }\end{array}$ & 7 & 7 \\
\hline $\begin{array}{c}\text { F - Utilização do vaso } \\
\text { sanitário }\end{array}$ & 1 & 1 & R-Memória & 7 & 7 \\
\hline $\begin{array}{l}\text { CONTROLE DE } \\
\text { ESFINCTERES }\end{array}$ & avaliação & reavaliação & TOTAL = & 61 & 61 \\
\hline G - Controle de urina & 1 & 1 & & & \\
\hline $\begin{array}{c}\mathrm{H}-\mathrm{C} \text { Controle das } \\
\text { fezes }\end{array}$ & 1 & 1 & & & \\
\hline MOBILIDADE & avaliação _ $_{-}$ & reavaliação & & & \\
\hline $\begin{array}{l}\text { I - Leito, cadeira, } \\
\text { cadeira de rodas }\end{array}$ & 1 & $\mathbf{1}$ & & & \\
\hline J - Vaso sanitário & 1 & 1 & & & \\
\hline $\begin{array}{c}\mathbf{K} \text { - Banheira, } \\
\text { chuveiro }\end{array}$ & 1 & 1 & & & \\
\hline LOCOMOÇÃO & avaliação & reavaliação & & & \\
\hline $\begin{array}{c}\mathrm{L} \text { - Marcha/ cadeira } \\
\text { de rodas }\end{array}$ & 1 & 1 & & & \\
\hline M - Escadas & 1 & 1 & & & \\
\hline
\end{tabular}

\section{SUJEITO 4 - Escala Funcional Específica do Paciente}

\begin{tabular}{|c|c|c|}
\hline Atividade & Aval. & Reaval. \\
\hline $\begin{array}{l}\text { 4- Alcançar um copo/garrafa a sua frente em } \\
\text { uma mesa (distancia } 10 \mathrm{~cm} \text { da beirada da } \\
\text { mesa) }\end{array}$ & 4 & 4 \\
\hline
\end{tabular}




\begin{tabular}{|l|l|l|}
\hline $\begin{array}{l}\text { 2- Alcançar um copo/garrafa a sua frente } \\
\text { em uma mesa (distancia } 45 \mathrm{~cm} \text { da beirada } \\
\text { da mesa) }\end{array}$ & 4 & 4 \\
\hline $\begin{array}{l}\text { 3- Alcançar um copo/garrafa do lado em } \\
\text { uma mesa (na beirada da mesa e com uma } \\
\text { distância de } 30 \mathrm{~cm} \text { a partir da lateral do } \\
\text { corpo testado) }\end{array}$ & 4 & 4 \\
\hline 4- Erguer o braço no armário acima da pia & 1 & 1 \\
\hline 5- Levar copo à boca com as duas mãos & 1 & 1 \\
\hline Total & 2,8 & 2,8 \\
\hline
\end{tabular}

SUJEITO 5 - MIF

\begin{tabular}{|c|c|c|c|c|c|}
\hline AUTOCUIDADO & avaliação & reavaliação & COMUNICAÇÃO & avaliação & reavaliação \\
\hline A - Alimentação & 5 & 5 & N - Compreensão & 7 & 7 \\
\hline B - Higiene pessoal & 4 & 4 & O - Expressão & 7 & 7 \\
\hline C-Banho & 4 & 4 & $\begin{array}{l}\text { COGNIÇÃO } \\
\text { SOCIAL }\end{array}$ & avaliação & reavaliação \\
\hline $\begin{array}{c}\text { D - Vestir metade } \\
\text { superior }\end{array}$ & 6 & 6 & P - Interação social & 7 & 7 \\
\hline $\begin{array}{c}\mathbf{E} \text { - Vestir metade } \\
\text { inferior }\end{array}$ & 3 & 3 & $\begin{array}{c}\mathrm{Q}-\text { Resolução de } \\
\text { problemas }\end{array}$ & 7 & 7 \\
\hline $\begin{array}{c}\text { F - Utilização do vaso } \\
\text { sanitário }\end{array}$ & 1 & 1 & R-Memória & 7 & 7 \\
\hline $\begin{array}{l}\text { CONTROLE DE } \\
\text { ESFINCTERES }\end{array}$ & avaliação & reavaliação & TOTAL $=$ & 73 & 73 \\
\hline G - Controle de urina & 1 & 1 & & & \\
\hline $\begin{array}{c}\mathrm{H} \text { - Controle das } \\
\text { fezes }\end{array}$ & 1 & 1 & & & \\
\hline MOBILIDADE & avaliaçãa $_{-}$ & reavaliação & & & \\
\hline $\begin{array}{l}\text { I - Leito, cadeira, } \\
\text { cadeira de rodas }\end{array}$ & 4 & 4 & & & \\
\hline J - Vaso sanitário & 1 & 1 & & & \\
\hline
\end{tabular}




\begin{tabular}{|c|c|c|c|}
\hline $\begin{array}{c}\text { K - Banheira, } \\
\text { chuveiro }\end{array}$ & 1 & 1 & \\
\hline LOCOMOÇÃo & avaliação & reavaliação \\
\hline $\begin{array}{c}\text { L- Marcha/ cadeira } \\
\text { de rodas }\end{array}$ & 6 & 6 & \\
\hline M- Escadas & 1 & 1 & \\
\hline
\end{tabular}

\section{SUJEITO 5 - Escala Funcional Específica do Paciente}

\begin{tabular}{|c|c|c|}
\hline Atividade & Aval. & Reaval. \\
\hline $\begin{array}{l}\text { 5- Alcançar um copo/garrafa a sua frente em } \\
\text { uma mesa (distancia } 10 \mathrm{~cm} \text { da beirada da } \\
\text { mesa) }\end{array}$ & 5 & 5 \\
\hline $\begin{array}{l}\text { 2- Alcançar um copo/garrafa a sua frente } \\
\text { em uma mesa (distancia } 45 \mathrm{~cm} \text { da beirada } \\
\text { da mesa) }\end{array}$ & 5 & 5 \\
\hline $\begin{array}{l}\text { 3- Alcançar um copo/garrafa do lado em } \\
\text { uma mesa (na beirada da mesa e com uma } \\
\text { distância de } 30 \mathrm{~cm} \text { a partir da lateral do } \\
\text { corpo testado) }\end{array}$ & 5 & 5 \\
\hline 4- Pegar objeto pequeno (moeda) & 1 & 1 \\
\hline 5- cortar alimentos & 1 & 1 \\
\hline Total & 3,0 & 3,0 \\
\hline
\end{tabular}


ANEXOS 


\section{ANEXO A - APROVAÇÃO DO COMITÊ DE ÉTICA}

Oficio $\mathrm{n}^{\circ} 4201 / 2015$

$\mathrm{CEP} / \mathrm{MGV}$

\section{PROCESSO HCRP $n^{\circ} 13695 / 2015$}

Prezadas Pesquisadoras,

O trabalho intitulado "ADEQUAÇÃO E USO DE NOVAS TECNOLOGIAS ROBÓTICAS PARA O TRATAMENTO DE ALTERACŌES MOTORAS NO MEMBRO SUPERIOR" - Projeto de Pesquisa Versão 2 de 25/10/2015, foi analisado pelo Comitê de Ética em Pesquisa, em sua $418^{a}$ Reunião Ordinária realizada em 23/11/2015, e enquadrado na categoria: APROVADO, bem como os Termos de Consentimento Livre e Esclarecido Versão 2 de 25/10/2015.

De acordo com Carta Circular $n^{\circ}$ 003/2011/CONEP/CNS, datada de 21/03/2011, o sujeito de pesquisa ou seu representante, quando for o caso, deverá rubricar todas as folhas do Termo de Consentimento Livre e Esclarecido - TCLE - apondo sua assinatura na última do referido Termo; o pesquisador responsável deverá da mesma forma, rubricar todas as folhas do Termo de Consentimento Livre e Esclarecido - TCLE - apondo sua assinatura na última página do referido Termo.

Este Comitê segue integralmente a Conferência Internacional de Harmonização de Boas Práticas Clinicas (IGH-GCP), bem como a Resolução no 466/2012 CNS/MS,

Lembramos que devem ser apresentados a este CEP, o Relatório Parcial e o Relatório Final da pesquisa.

Atenciosamente.

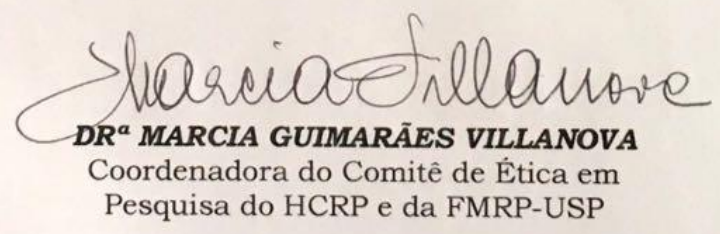

Ilustríssimas Senhoras

GABRIELA CASEIRO ALMEIDA SILVA

PROF $^{a}$ DR $^{a}$ VALÉRIA MEIRELLES CARRIL ELUI (Orientadora)

Depto. de Neurociências e Ciências do Comportamento - Terapia Ocupacional

HOSPITAL DAS CLINICAS DA FACULDADE DE MEDICINA DE RIBEIRÃO PRETO DA UNIVERSIDADE DE SÃO PAULO Campus Universitário - Monte Alegre

14048-900 Ribeirấo Preto SP

Comitê de Ética em Pesquisa do HCRP e FMRP-USP FWA-00002733: IRB-00002186 Registro Plataforma Brasil /CONEP n 5440 (016) 3602-2228

www.hcrp.usp.br cep@hcrp.usp.br 